\title{
SELECTED GROUND-WATER DATA FOR YUCCA MOUNTAIN REGION, SOUTHERN NEVADA AND EASTERN CALIFORNIA,THROUGH DECEMBER 1994
}

\section{U.S. GEOLOGICAL SURVEY}

Open-File Report 96-205

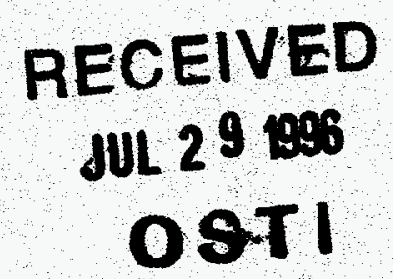

Prepared in cooperation with the NEVADA OPERATIONS OFFICE, U.S. DEPARTMENT OF ENERGY, under Interagency Agreement DE-AI08-92NV10874
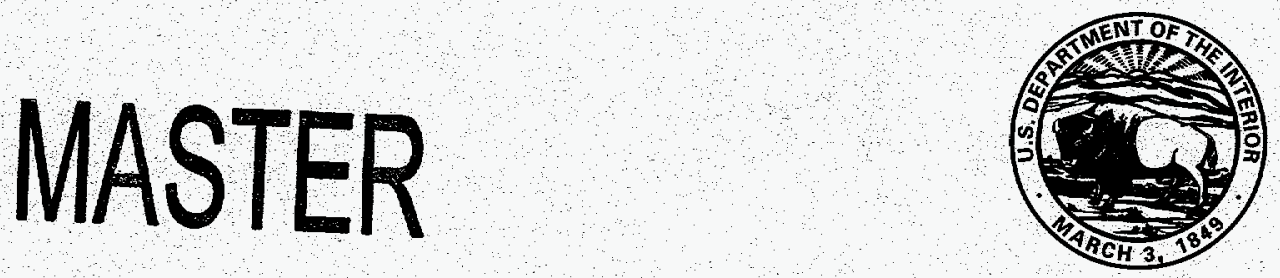



\title{
SELECTED GROUND-WATER DATA FOR YUCCA MOUNTAIN REGION, SOUTHERN NEVADA AND EASTERN CALIFORNIA, THROUGH DECEMBER 1994
}

\author{
by Craig L. Westenburg and Richard J. La Camera
}

\section{U.S. GEOLOGICAL SURVEY}

Open-File Report 96-205

Prepared in cooperation with the

NEVADA OPERATIONS OFFICE,

U.S. DEPARTMENT OF ENERGY, under

Interagency Agreement DE-Al08-92NV10874

\section{DISCLAIMER}

This report was prepared as an account of work sponsored by an agency of the United States Government. Neither the United States Government nor any agency thereof, nor any of their employees, makes any warranty, express or implied, or assumes any legal liability or responsibility for the accuracy, completeness, or usefulness of any information, apparatus, product, or process disclosed, or represents that its use would not infringe privately owned rights. Reference herein to any specific commercial product, process, or service by trade name, trademark, manufacturer, or otherwise does not necessarily constitute or imply its endorsement, recommendation, or favoring by the United States Government or any agency thereof. The views and opinions of authors expressed herein do not necessarily state or reflect those of the United States Government or any agency thereof.

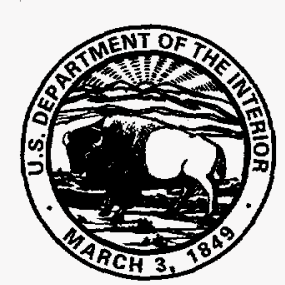

Carson City, Nevada 1996 


\title{
U.S. DEPARTMENT OF THE INTERIOR BRUCE BABBITT, Secretary
}

\author{
U.S. GEOLOGICAL SURVEY \\ Gordon P. Eaton, Director
}

Any use of trade names in this publication is for descriptive purposes

only and does not constitute endorsement by the U.S. Government.

For additional information write to:

District Chief

U.S. Geological Survey

333 West Nye Lane, Room 203

Carson City, NV 89706-0866
Copies of this report can be purchased from:

U.S. Geological Survey

Information Services

Box 25286, MS 517

Denver Federal Center

Denver, CO 80225-0046 


\section{DISCLAIMER}

Portions of this document may be illegible in electronic image products. Images are produced from the best available original document. 



\section{CONTENTS}

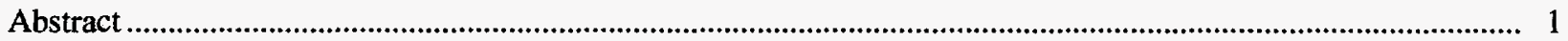

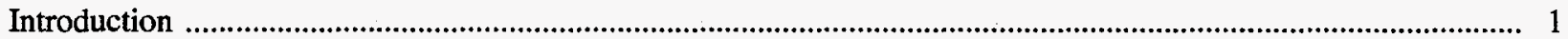

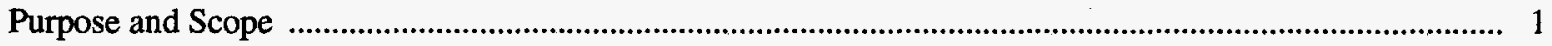

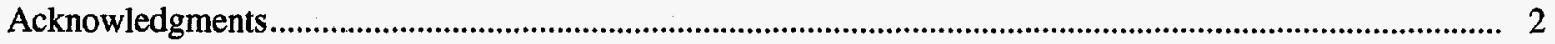

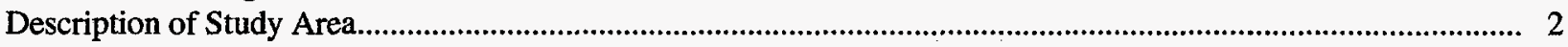

Alkali Flat-Furnace Creek Ranch Ground-Water Subbasin ........................................................................... 2

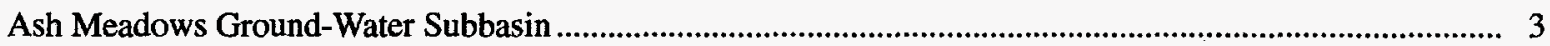

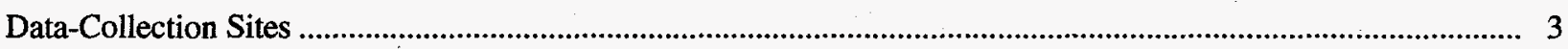

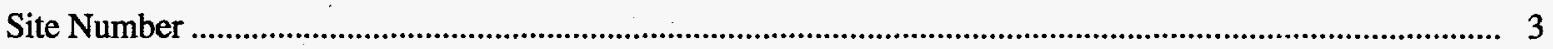

U.S. Geological Survey Site Identification ............................................................................................... 3

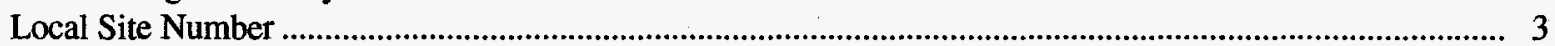

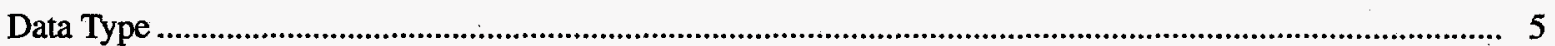

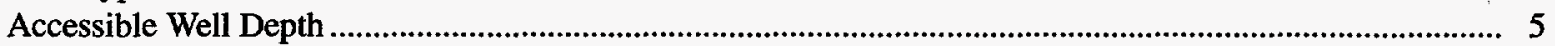

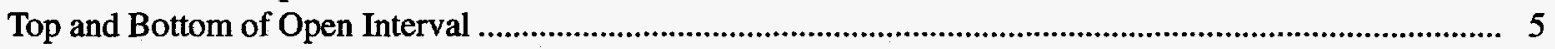

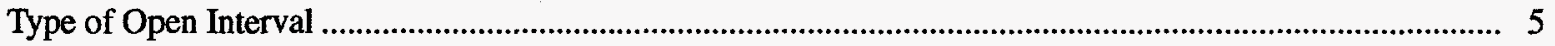

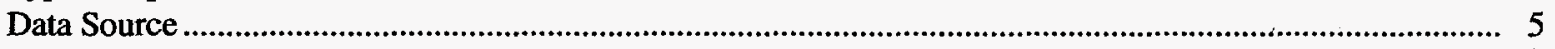

Contributing Lithologic Units ................................................................................................................... 5

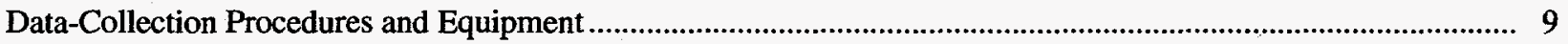

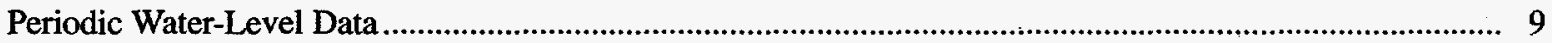

Land-Surface Altitude and Height of Measurement Point............................................................... 9

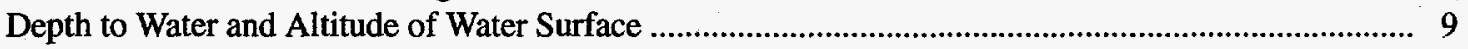

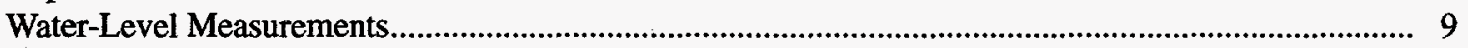

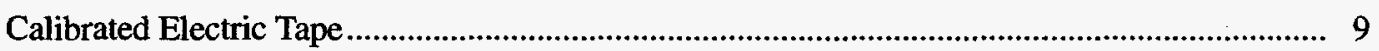

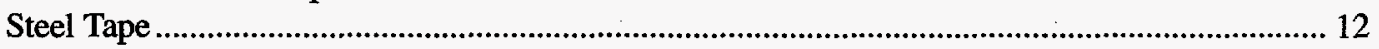

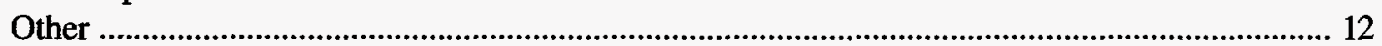

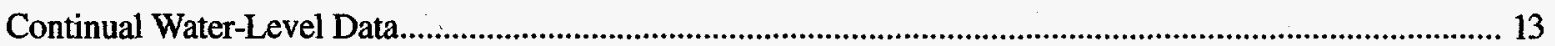

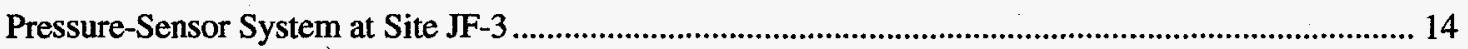

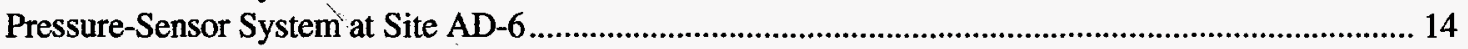

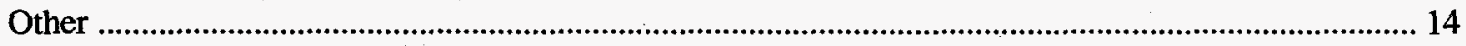

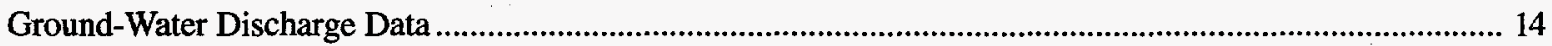

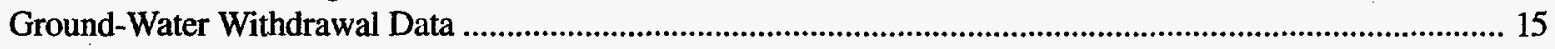

Withdrawals from Alkali Flat-Furnace Creek Ranch Ground-Water Subbasin...................................... 15

Withdrawals from Ash Meadows Ground-Water Subbasin ......................................................................... 16

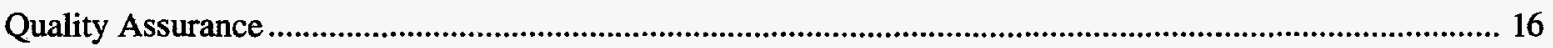

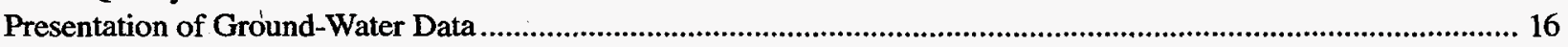

Discussion of Ground-Water Levels and Ground-Water Withdrawals in Jackass Flats ......................................... 17

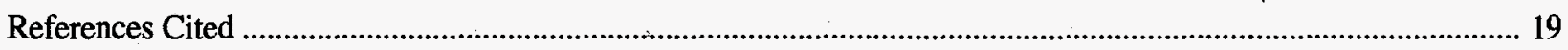

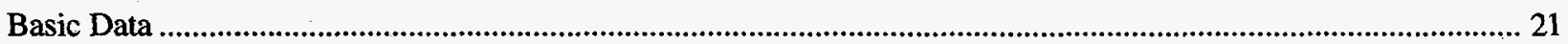

\section{PLATE}

[Plate is in pocket]

1. Map showing location of data-collection sites for calendar year 1994, Yucca Mountain region of southern Nevada and eastern California 


\section{FIGURES}

1-4. Graphs showing periodic water levels through 1994 for selected sites at which primary contributing units are:

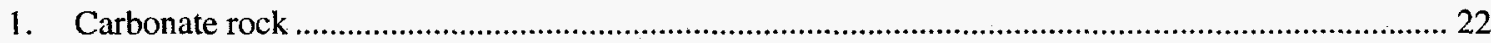

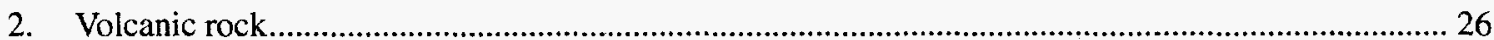

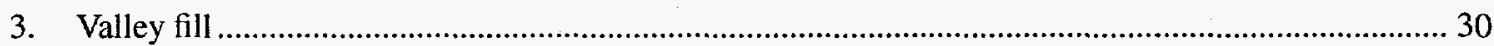

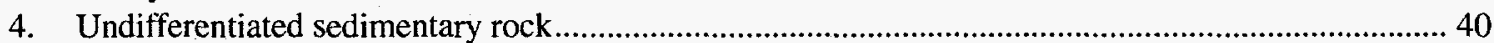

5-6. Graphs showing daily average water levels in:

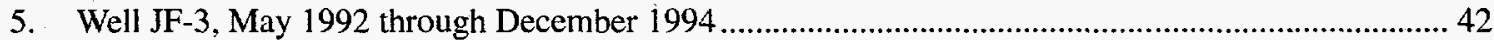

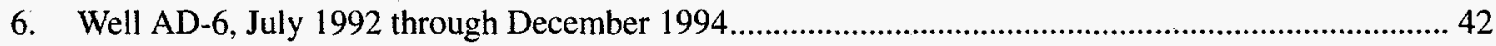

7-9. Graphs showing discharge at:

7. Sites AM-1a (Fairbanks Spring), AM-5a (Crystal Pool), and AM-8 (Big Spring) through 1994 ....... 43

8. Sites AM-2 (Five Springs Well) and DV-2 (Navel Spring), 1990 through 1994 …............................. 44

9. Site DV-1 (Texas Spring), 1989 through 1994 ................................................................................... 45

10-11. Graphs showing available estimates of annual ground-water withdrawals for selected areas within:

10. Alkali Flat-Furnace Creek Ranch ground-water subbasin, 1961 through 1994 ................................. 46

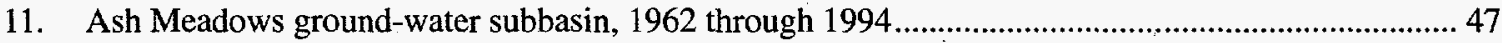

12. Graphs showing water-level altitudes in wells JF-1, JF-2, JF-2a, J-13, J-11, J-12, and JF-3, and estimated ground-water withdrawals from Jackass Flats, 1983 through 1994

13. Graphs showing median water-level altitudes and average deviation of water levels for wells JF-1, JF-2, JF-2a, J-13, J-11, J-12, and JF-3 for selected baseline periods, and for calendar years 1992 through 1994

\section{TABLES}

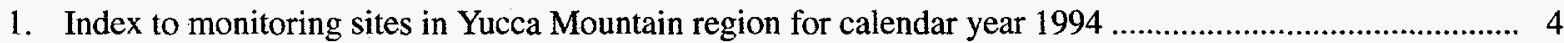

2. Well-completion data at monitoring sites in Yucca Mountain region ....................................................... 6

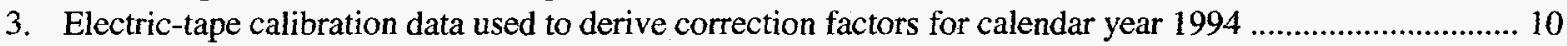

4. Applied correction factors for electric tapes YMP-1, YMP-2, YMP-5, and YMP-6 ............................... 11

5. Periodic measurements of water levels at monitoring sites in Yucca Mountain region for calendar year 1994

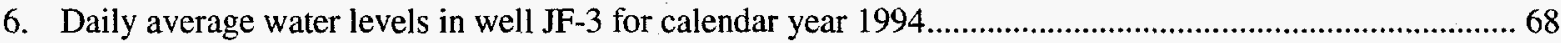

7. Daily average water levels in well AD-6 for calendar year 1994..................................................................69 69

8. Ground-water-discharge data in Yucca Mountain region for calendar year 1994 ........................................ 70

9. Estimated annual ground-water withdrawals from wells in Yucca Mountain region for calendar year 1994

10. Minimum, maximum, and median water-level altitudes, and average deviation of measurements, at wells in Jackass Flats for selected baseline periods and for calendar years 1992 through 1994

\section{CONVERSION FACTORS AND VERTICAL DATUM}

\begin{tabular}{rcl}
\hline Multiply & By & To Obtain \\
\hline acre-foot (acre-ft) & 1,233 & cubic meter \\
foot (ft) & 0.3048 & meter \\
gallon per minute (gal/min) & 0.06309 & liter per second \\
inch (in.) & 2.540 & centimeter \\
mile (mi) & 1.609 & kilometer \\
million gallons (Mgal) & 3,785 & cubic meter \\
pound per square inch (lb/in') & 6.896 & kilopascal \\
\hline
\end{tabular}

Sea level: In this report, "sea level" refers to the National Geodetic Vertical Datum of 1929 (NGVD of 1929, formerly called "SeaLevel Datum of 1929"), which is derived from a general adjustment of the first-order leveling networks of the United States and Canada. 
Westenburg (1995) present data through calendar year 1993 in the second report of the series. Hereafter, the first two reports of this series are referred to as previous reports on selected ground-water data for the Yucca Mountain region.

Additional information for sites $\mathrm{CF}-2, \mathrm{JF}-1, \mathrm{JF}-2$, $\mathrm{JF}-2 \mathrm{a}, \mathrm{J}-13, \mathrm{~J}-11$, and $\mathrm{J}-12$ is presented by Boucher (1994), Gemmell (1990), Lobmeyer and others (1995), Luckey and others (1993), McKinley and others (1991), O'Brien (1991, 1993), O'Brien and others (1995), Robison (1984), Robison and others (1988), and Tucci and others (in press $a$, in press $b$ ).

\section{Acknowledgments}

Several organizations and programs contributed to this report. Specifically, data were provided by National Park Service; U.S. Fish and Wildlife Service; Nevada Department of Conservation and Natural Resources, Division of Water Resources; Nevada Department of Transportation; Cind-R-Lite Company; Raytheon Services Nevada; Reynolds Electrical and Engineering Company; Saga Exploration Company; U.S. Borax Corporation; U.S. Nevada Gold Search; USGS-Hydrologic Resources Management and Environmental Restoration Programs; and USGS-Yucca Mountain Project Branch studies of saturated-zone site hydrology and saturated-zone regional hydrology.

Additionally, the authors acknowledge the cooperation of the many individual property owners throughout the Amargosa Desert who allowed access to their property and the collection of hydrologic data.

\section{DESCRIPTION OF STUDY AREA}

The study area is the Yucca Mountain region of southern Nevada and eastern California (pl. 1). The Yucca Mountain region, as referred to in this report, is bounded approximately by latitudes $36^{\circ} 15^{\prime}$ and $37^{\circ} 00^{\prime}$ $\mathrm{N}$. and longitudes $116^{\circ} 00^{\prime}$ and $117^{\circ} 00^{\prime} \mathrm{W}$. The region is within the Great Basin, a subdivision of the Basin and Range Physiographic Province (Fenneman, 1931, p. 328).

The study area is in the Death Valley ground-water flow system (Harrill and others, 1988, sheet 1) and, within that flow system, the Alkali Flat-Furnace Creek Ranch and Ash Meadows ground-water subbasins. Each ground-water subbasin is a zone consisting of ground-water recharge areas and flow paths to points of discharge at land surface (Waddell and others, 1984, p. 36 and pl. 3; Randell J. Laczniak, U.S. Geological Survey, written commun., 1993). Boundaries of the subbasins are defined on the basis of the location of low-permeability rocks, hydraulic gradients, and water chemistry. These boundaries are general indicators of restrictions on ground-water movement in the region.

Within the Alkali Flat-Furnace Creek Ranch and Ash Meadows subbasins, the study area is further subdivided by hydrographic areas (pl. 1). As defined by Rush (1968, p. 4), hydrographic areas generally consist of valleys (topographic lows) extending to their surrounding surface-water drainage divides (topographic highs). Hydrographic areas in the study area include Crater Flat, Jackass Flats, most of Rock Valley and Mercury Valley, and parts of Amargosa Desert and Death Valley (Rush, 1968; Harrill and others, 1988, sheet 2).

\section{Alkali Flat-Furnace Creek Ranch Ground-Water Subbasin}

In the Alkali Flat-Furnace Creek Ranch groundwater subbasin, ground-water recharge results principally from subsurface interbasin inflow and precipitation on mesas and mountains north of the study area. Subsurface interbasin inflow also may occur near the Ash Meadows area in the Amargosa Desert (Waddell and others, 1984, p. 29-36; Harrill and others, 1988, sheet 2). Ground water discharges principally in Death Valley and at Alkali Flat about $5 \mathrm{mi}$ southeast of Death Valley Junction (Waddell and others, 1984, p. 38).

In the part of the subbasin within the northern half of the study area, ground-water flow is generally to the south or southeast. In the part of the subbasin within the southern half of the study area, ground-water flow is to the southeast toward Alkali Flat or southwest toward Death Valley (Waddell and others, 1984, pl. 3; Kilroy, 1991, p. 9-10).

Crater Flat and Jackass Flats (which include Yucca Mountain), most of Rock Valley, the west-central part of the Amargosa Desert, and part of the Death Valley hydrographic areas are within the Alkali Flat-Furnace Creek Ranch subbasin (pl. 1). 


\section{Ash Meadows Ground-Water Subbasin}

In the Ash Meadows ground-water subbasin, ground-water recharge principally results from subsurface interbasin inflow and precipitation on mountains to the east and northeast of the study area (Waddell and others, 1984, p. 38; Harrill and others, 1988, sheet 2). Ground water discharges principally as springflow in the Ash Meadows area, and possibly as underflow into the Alkali Flat-Furnace Creek Ranch ground-water subbasin (Waddell and others, 1984, p. 36, 39). Ground water in the subbasin generally flows to the west or southwest (Waddell and others, 1984, p. 29, 38, and pl. 3; Harrill and others, 1988, sheet 2).

Most of Mercury Valley and the eastern part of the Amargosa Desert hydrographic areas are within the Ash Meadows subbasin (pl. 1). The southeastern part of the Amargosa Desert includes the Ash Meadows spring-discharge area. The Ash Meadows springdischarge area is the gently sloping land watered by numerous springs (Dudley and Larson, 1976, p. 5) at the southwestern edge of the subbasin.

\section{DATA-COLLECTION SITES}

Locations of data-collection sites are shown on plate 1. Table 1 includes information on site identification, site location, site owner, and the types of data contained in this report for each site. Table 2 includes information on site identification, well construction, source of well-construction data, and contributing lithologic units. Monitoring site MV-1 did not have water-level data available in 1994, but is included because it is a part of the monitoring network. Sites CF-3, AD-3a, and AD-7a were added to the monitoring network in 1994 to replace sites AD-3, in which the water surface became inaccessible in 1993, AD-4, which is no longer measured at the owner's request, and AD-7, which was redrilled and developed by the new owner in 1994. All sites are wells or springs except site AM-4 (Devils Hole), which is an open fissure that intersects the ground-water table.

\section{Site Number}

Sites are identified on plate 1 and in table 1 by an alphanumeric number that also is used in tables, figures, and text of this report. The site number consists of two parts. The first part represents the hydrographic area in which the site is located: "CF" represents Crater Flat; "JF" or "J," Jackass Flats; "RV," Rock Valley; "MV," Mercury Valley; “AD" or "AM," Amargosa Desert; and "DV," Death Valley. "AM" further indicates that the site is located in the Ash Meadows spring-discharge area. The second part of the number represents the relative location of the site within the hydrographic area (or Ash Meadows spring-discharge area). Within each hydrographic area, sites generally are numbered sequentially in a north-to-south, then west-to-east order. Sites added subsequent to the initial numbering also are numbered as indicated above or are assigned the number of a nearby site and given the suffix of "a." Exceptions are sites J-13, J-11, and J-12, which are or were water-supply wells and were previously numbered by Raytheon Services Nevada; they were not renumbered for this report. The sequence of sites given in table 1 is used elsewhere throughout the report.

\section{U.S. Geological Survey Site Identification}

Sites are identified by the standard U.S. Geological Survey identification number, which is based on latitude and longitude. The site identification serves as a unique identification number in files and data bases of the USGS and indicates the approximate geographic location of each site. The identification consists of 15 digits: The first 6 denote the degrees, minutes, and seconds of latitude; the next 7 denote degrees, minutes, and seconds of longitude; and the last 2 digits (assigned sequentially) identify the site within a 1-second grid. For example, site 363530116021401 is at $36^{\circ} 35^{\prime} 30^{\prime \prime}$ latitude and $116^{\circ} 02^{\prime} 14^{\prime \prime}$ longitude, and it is the first site recorded in that 1-second grid. If a more precise latitude and longitude are subsequently determined, the unique identification number remains unchanged. Latitude and longitude shown for a site, therefore, are the most accurate locators.

\section{Local Site Number}

The local site number (table 1) is based on an index of hydrographic areas (Rush, 1968; Harrill and others, 1988 ) and the rectangular subdivision of the public 
Table 1. Index to monitoring sites in Yucca Mountain region for calendar year 1994

Site number: Sites are grouped by hydrographic area and, within each area, are listed in general north-to-south, then west-to-east order. See text section titled "Site Number" for further discussion.

U.S. Genlogical Sucvey site identification: Unique identification number for sites as stored in files and data bases of U.S. Geological Survey.

Local site number: Alphanumeric number based on location of site within hydrographic areas and rectangular subdivisions of public lands. See text section titled "Local Site Number" for further discussion.

Owner: Abbreviations listed for sites owned by federal agencies: BLM, Bureau of Land Management; NPS, National Park Service; USDOE, U.S. Department of Energy; USFWS, U.S. Fish and Wildlife Service; USGS, U.S. Geological Survey.

Datatype: Type of data included in this report. D, ground-water discharge; L, ground-water level; --, data not available for 1994.

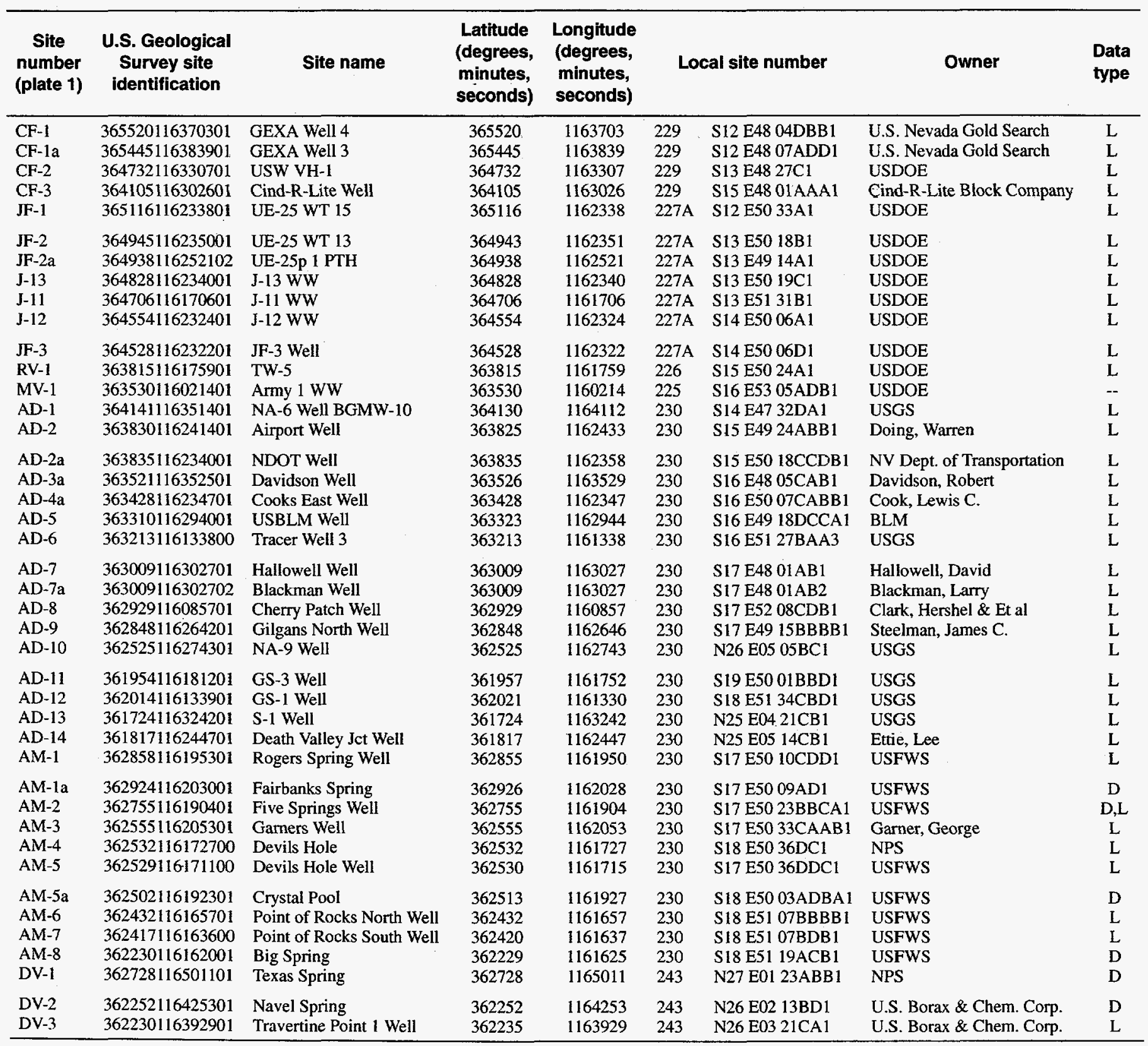


lands referenced to the Mount Diablo base line and meridian for sites in Nevada or San Bernadino base line and meridian for sites in California. Each local site number consists of four units separated by spaces: The first unit is the hydrographic area number. The second unit is the township, preceded by an $\mathrm{N}$ or $\mathrm{S}$ to indicate location north or south of the base line. The third unit is the range, preceded by an $\mathrm{E}$ to indicate location east of the meridian. The fourth unit consists of the section number and letters designating the quarter section, quarter-quarter section and so on $(\mathrm{A}, \mathrm{B}, \mathrm{C}$, and $\mathrm{D}$, indicate the northeast, northwest, southwest, and southeast quarters, respectively), followed by a number indicating the sequence in which the well was recorded. For example, site 230 S18 E51 34CBD1 is in the Amargosa Desert (hydrographic area 230) and is the first site recorded in the southeast quarter of the northwest quarter of the southwest quarter of section 34, Township 18 South, Range 51 East, Mount Diablo base line and meridian.

\section{Data Type}

Data type (table 1) identifies the types of data (water level and discharge) presented for each site. Ground-water-level data are in tables 5-7 and groundwater-discharge data are in table 8.

\section{Accessible Well Depth}

Accessible well depth (table 2) is the measurable depth to the bottom of the well. The drilled depth may be greater than the depth of the well due to modifications of the well, obstructions, or accumulation of sediment at the bottom of the well. The depth of each well was measured by USGS (depths noted with "s") or was reported by other data sources. The USGS measured depths less than $1,000 \mathrm{ft}$ by "sounding" the bottom of the well with weighted steel or electric tapes.

\section{Top and Bottom of Open Interval}

Open intervals (table 2) are parts of the borehole that are open to the surrounding lithologic intervals and may allow water to enter the well. An uncased section of a borehole is considered an open interval in this report.

\section{Type of Open Interval}

Type of open interval (table 2) is a physical description of the open intervals of a borehole. The types of openings are perforated or slotted casing, screened casing, and open hole with no casing.

\section{Data Source}

Data sources (table 2) are organizations or publications that provided information on depth of the well, open interval, and type of opening. Drillers' logs or records are filed with the Nevada Division of Water Resources (NDWR) or maintained by the well owner; Fenix and Scisson, Inc., and Raytheon Services Nevada are or were contractors for USDOE and maintain a summary of well-construction information for selected wells in the area. Publications are USGS reports written for USDOE as part of cooperative studies associated with weapons-testing hydrology programs (Thordarson and others, 1967; Johnston, 1968) or Yucca Mountain site-characterization studies (Robison and others, 1988; Luckey and others, 1993).

\section{Contributing Lithologic Units}

Contributing units (table 2) are the principal lithologic intervals at the site that yield water to the well. Robison and others (1988) describe the contributing units at sites CF-2, JF-1, JF-2, JF-2a, and J-13. McKinley and others (1991) describe the contributing units for sites J-11, J-12, MV-1, AD-4a, AD-5, AD-6, AD-8, and AM-8. Dudley and Larson (1976) describe the contributing units for sites AM-2, AM-5, and AM-7. Contributing-unit data are not available from listed data sources for some wells; the contributing units indicated for those wells are based on geologic data derived from drillers' logs and depth-to-water data. 
Table 2. Well-completion data at monitoring sites in Yucca Mountain region

Site number: Sites are grouped by hydrographic area and, within each area, are listed in general north-to-south, then west-to-east order. See section "Site Number" for further discussion. U.S.Geological Survey site identification: Unique identification number for site as stored in files and data bases of U.S. Geological Survey (USGS).

Accessible well depth: Well depths listed are as reported in sources listed in explanation for Data Source below or as measured by USGS personnel since September 1990 (noted with 's'). See section "Accessible Well Depth" for further discussion.

Casing diameter at land surface: Casing segment most prominent at land surface. Diameters have been rounded to nearest inch.

Top of open interval: Depth to top part(s) of borehole that can receive ground water from lithologic interval. As reported in sources listed in explanation for Data Source. Uncased borchole is designated open interval in this table. Open interval may be deeper than accessible well depth, which may reflect original drilled depth. U, unknown, no data.

Bottom of open interval: Depth to bottom part(s) of borehole that can receive ground water from lithologic interval. As reported in sources listed in explanation for Data Source. Uncased borehole is designated open interval in this table. Open interval may he deeper than accessible well depth, which may reflect original drilled depth. U, unknown, no data.

Diameter of open interval: Casing diameter has been rounded to nearest inch. Hole diameter is listed where no casing is present. U, unknown, no data.

Type of open interval: Description of open interval. P, perforated or slotted casing; S, screen, type not known; U, unknown, no data; $X$, uncased borehole.

Data source: D, Nevada well driller’s log or report, or Fenix \& Scisson, Inc., or Raytheon Services Nevada hole-history data; J, Johnston (1968); L, Luckey and others (1993); M, no source, data not available; O, Owner of well; R, Robison and others (1988); $T$, Thordarson and others (1967).

Contributing units: Saturated lithologic interval yielding water to well. C, carbonate rock; F, valley fill; S, undifferentiated sedimentary rock; V, volcanic rock.

\begin{tabular}{|c|c|c|c|c|c|c|c|c|c|c|}
\hline \multirow{3}{*}{$\begin{array}{c}\text { Site } \\
\text { number } \\
\text { (plate 1) }\end{array}$} & \multirow{3}{*}{$\begin{array}{l}\text { U.S. Geological } \\
\text { Survey site } \\
\text { identification }\end{array}$} & \multirow{3}{*}{ Site name } & \multirow{3}{*}{$\begin{array}{c}\text { Accessible } \\
\text { well depth } \\
\text { (feet below } \\
\text { land } \\
\text { surface) }\end{array}$} & \multirow{3}{*}{$\begin{array}{l}\text { Casing } \\
\text { diameter } \\
\text { at land } \\
\text { surface } \\
\text { (inches) }\end{array}$} & \multicolumn{4}{|c|}{ Open interval } & \multirow{3}{*}{$\begin{array}{l}\text { Data } \\
\text { source }\end{array}$} & \multirow{3}{*}{$\begin{array}{c}\text { Contributing } \\
\text { units }\end{array}$} \\
\hline & & & & & \multicolumn{2}{|c|}{$\begin{array}{l}\text { Feet below land } \\
\text { surface }\end{array}$} & \multirow{2}{*}{$\begin{array}{l}\text { Diameter } \\
\text { (inches) }\end{array}$} & \multirow{2}{*}{ Type } & & \\
\hline & & & & & Top & Bottom & & & & \\
\hline CF-I & 365520116370301 & GEXA Well 4 & 1,600 & 15 & 800 & 1,600 & 10 & $P$ & D & V \\
\hline CF-1a & 365445116383901 & GEXA Well 3 & 700 & 7 & $\begin{array}{l}208 \\
513 \\
658\end{array}$ & $\begin{array}{l}313 \\
618 \\
700\end{array}$ & $\begin{array}{l}6 \\
6 \\
6\end{array}$ & $\begin{array}{l}P \\
P \\
P\end{array}$ & D & $S$ \\
\hline $\mathrm{CF}-2$ & 364732116330701 & USW VH-1 & 2,501 & 10 & 911 & 2,501 & 6 & $X$ & $\mathrm{R}$ & V \\
\hline CF-3 & 364105116302601 & Cind-R-Lite Well & 460 & 9 & 320 & 460 & 8 & $\mathbf{P}$ & D & S \\
\hline JF-1 & 365116116233801 & UE-25 WT 15 & 1,360 & 11 & $\begin{array}{l}127 \\
130\end{array}$ & $\begin{array}{r}130 \\
1,360\end{array}$ & $\begin{array}{r}15 \\
9\end{array}$ & $\begin{array}{l}X \\
X\end{array}$ & $\mathbf{R}$ & $\mathrm{V}$ \\
\hline $\mathrm{JF}-2$ & 364945116235001 & UE-25 WT 13 & 1,160 & 11 & $\begin{array}{r}222 \\
224 \\
1,150\end{array}$ & $\begin{array}{r}224 \\
1,150 \\
1,160\end{array}$ & $\begin{array}{r}15 \\
9 \\
8\end{array}$ & $\begin{array}{l}X \\
X \\
X\end{array}$ & D & V \\
\hline$J F-2 a$ & 364938116252102 & UE-25p 1 PTH & 5,923 & 24 & $\begin{array}{l}4,256 \\
4,279 \\
5,900\end{array}$ & $\begin{array}{l}4,279 \\
5,900 \\
5,923\end{array}$ & $\begin{array}{r}10 \\
7 \\
6\end{array}$ & $\begin{array}{l}X \\
X \\
X\end{array}$ & $\mathrm{~L}$ & $\mathrm{C}$ \\
\hline$J-13$ & $36482811 u 234001$ & $\mathrm{~J}-13 \mathrm{WW}$ & 3,488 & 13 & $\begin{array}{r}996 \\
1,301 \\
2,690 \\
3,385\end{array}$ & $\begin{array}{l}1,301 \\
1,386 \\
3,312 \\
3,488\end{array}$ & $\begin{array}{r}13 \\
12 \\
5 \\
8\end{array}$ & $\begin{array}{l}P \\
P \\
P \\
X\end{array}$ & $\mathrm{~T}$ & V \\
\hline
\end{tabular}




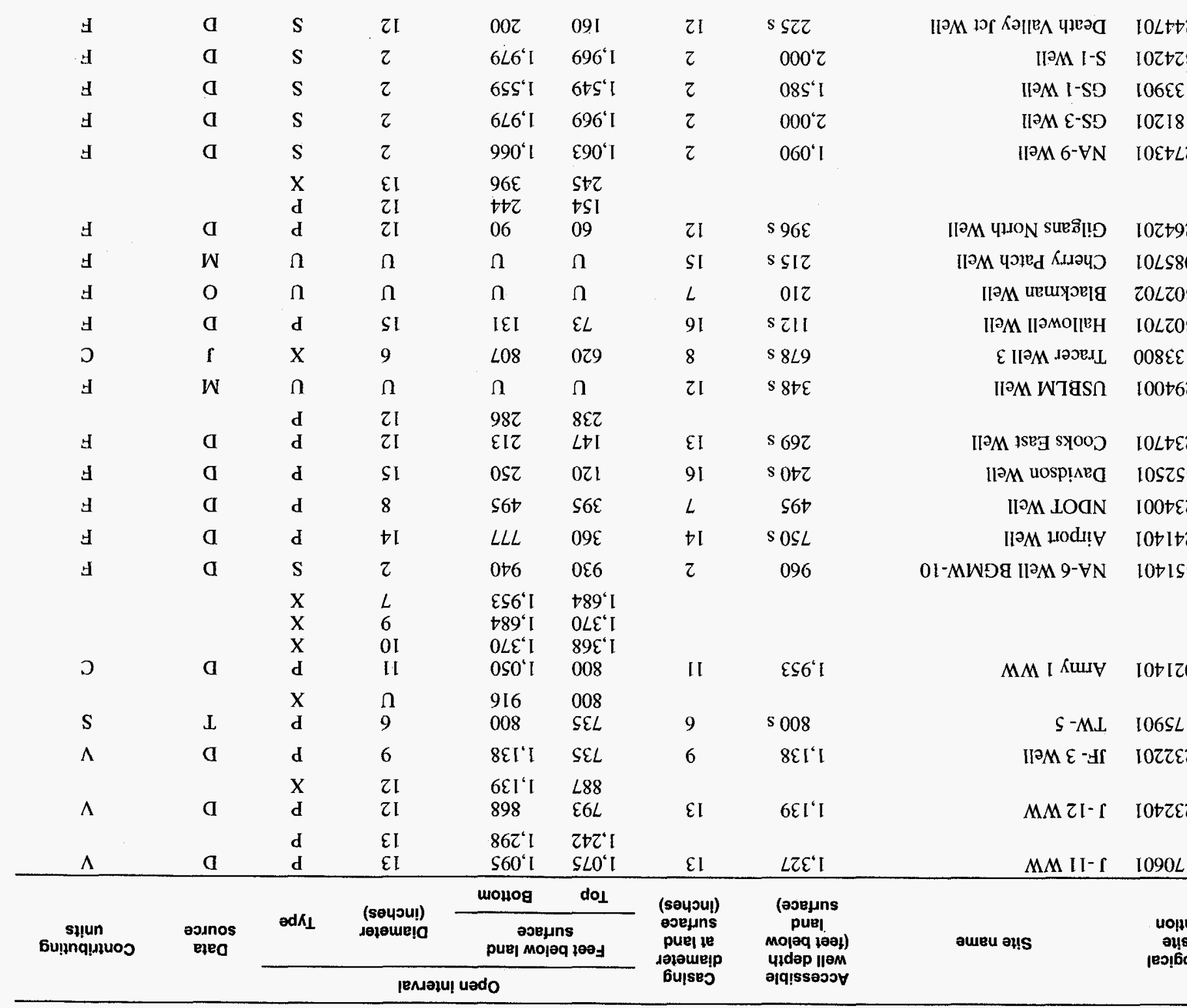

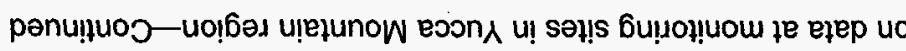


t monitoring sites in Yucca Mountain region-Continued

\begin{tabular}{|c|c|c|c|c|c|c|c|c|}
\hline \multirow{3}{*}{ Site name } & \multirow{3}{*}{$\begin{array}{c}\text { Accessible } \\
\text { well depth } \\
\text { (feet below } \\
\text { land } \\
\text { surface) }\end{array}$} & \multirow{3}{*}{$\begin{array}{l}\text { Casing } \\
\text { diameter } \\
\text { at land } \\
\text { surface } \\
\text { (inches) }\end{array}$} & \multicolumn{4}{|c|}{ Open interval } & \multirow{3}{*}{$\begin{array}{c}\text { Data } \\
\text { source }\end{array}$} & \multirow{3}{*}{$\begin{array}{c}\text { Contributing } \\
\text { units }\end{array}$} \\
\hline & & & \multicolumn{2}{|c|}{$\begin{array}{l}\text { Feet below land } \\
\text { surface }\end{array}$} & \multirow{2}{*}{$\begin{array}{l}\text { Diameter } \\
\text { (inches) }\end{array}$} & \multirow{2}{*}{ Type } & & \\
\hline & & & Top & Bottom & & & & \\
\hline Rogers Spring Well & $202 \mathrm{~s}$ & 16 & $\begin{array}{l}100 \\
240\end{array}$ & $\begin{array}{l}240 \\
420\end{array}$ & $\begin{array}{l}12 \\
13\end{array}$ & $\begin{array}{l}\mathrm{P} \\
\mathrm{X}\end{array}$ & D & $\mathrm{F}$ \\
\hline Five Springs Well & $123 \mathrm{~s}$ & 13 & $\begin{array}{r}0 \\
100\end{array}$ & $\begin{array}{l}100 \\
140\end{array}$ & $\begin{array}{l}13 \\
14\end{array}$ & $\begin{array}{l}P \\
X\end{array}$ & D & C \\
\hline Garners Well & $202 \mathrm{~s}$ & 9 & 140 & 180 & 8 & $P$ & $\mathrm{O}$ & $\mathbf{F}$ \\
\hline Devils Hole Well & $200 \mathrm{~s}$ & 17 & 48 & 248 & 16 & $P$ & D & F \\
\hline Point of Rocks North Well & 500 & 15 & 139 & 500 & 16 & $P$ & $\mathrm{D}$ & F \\
\hline Point of Rocks South Well & $586 \mathrm{~s}$ & 17 & $\begin{array}{l}132 \\
468\end{array}$ & $\begin{array}{l}467 \\
818\end{array}$ & $\begin{array}{l}14 \\
14\end{array}$ & $\begin{array}{l}\mathrm{P} \\
\mathrm{X}\end{array}$ & $\mathrm{D}$ & $\mathrm{C}$ \\
\hline Travertine Point 1 Well & $650 \mathrm{~s}$ & 4 & 100 & 970 & 5 & $\mathrm{X}$ & D & $\mathrm{C}$ \\
\hline
\end{tabular}


Table 3. Electric-tape calibration data used to derive correction factors for calendar year 1994-Continued

\begin{tabular}{|c|c|c|c|c|c|}
\hline \multirow[b]{2}{*}{ Date } & \multirow[b]{2}{*}{ Location } & \multirow[b]{2}{*}{ Tape used } & \multicolumn{2}{|c|}{ Depth below measuring point } & \multirow{2}{*}{$\begin{array}{l}\text { Correctior } \\
\text { (feet) }\end{array}$} \\
\hline & & & $\begin{array}{l}\text { Uncorrected } \\
\text { (feet) }\end{array}$ & $\begin{array}{l}\text { Corrected } \\
\text { (feet) }\end{array}$ & \\
\hline $01 / 12 / 95$ & $\mathrm{~J}-12$ & $\begin{array}{l}\text { USGS-SCP ST } \\
\text { YMP-1 } \\
\text { YMP-5 }\end{array}$ & $\begin{array}{l}745.39 \\
746.16 \\
744.94\end{array}$ & $\begin{array}{l}745.36 \\
745.36 \\
745.36\end{array}$ & $\begin{array}{r}-.03 \\
-.80 \\
+.42\end{array}$ \\
\hline & $\mathrm{CF}-2$ & $\begin{array}{l}\text { USGS-SCP ST } \\
\text { YMP-5 }\end{array}$ & $\begin{array}{l}605.20 \\
604.93\end{array}$ & $\begin{array}{l}605.16 \\
605.16\end{array}$ & $\begin{array}{r}-.04 \\
+.23\end{array}$ \\
\hline $01 / 18 / 95$ & $\mathrm{AD}-1$ & $\begin{array}{l}\text { USGS-EMP ST } \\
\text { YMP-5 }\end{array}$ & $\begin{array}{l}271.26 \\
271.28\end{array}$ & $\begin{array}{l}271.26 \\
271.26\end{array}$ & $\begin{array}{r}.00 \\
-.02\end{array}$ \\
\hline
\end{tabular}

No corrections were necessary for the USGS-EMP reference steel tape. The correction for the electric tapes is the difference between the corrected USGSSCP measurement or USGS-EMP steel-tape measurement and the USGS-EMP uncorrected measurement.

A summary of correction factors applied to USGSEMP electric tapes, based on calibration data, is listed in table 4 . These correction factors were computed from the corrections determined during tape calibrations listed in table 3 and account for mechanical stretch, inaccurate markings, and physical condition of electric tapes. The appropriate correction factor for electric-tape water-level measurements was determined by the date and depth to water listed in table 4 . The correction factor used for a certain tape at a particular depth and time may represent the average of several corrections listed in table 3 . For some measurement periods, the correction factor varied from the start of the period to the end of the period. The beginning and ending correction factors are shown in table 4 (represented by "to") and are evenly distributed with time through the measurement period. The measurement period represents the period in which those correction factors were used for the given depth-towater range using a given electric tape.

Calibrated electric tapes were used at all sites when frequent repetitive measureme ts were required due to fluctuating water levels or depths to water were greater than $\mathbf{5 0 0}$ feet. Electric-tape measurements are made by lowering the tape to the water surface until a light or buzzer is activated when the probe contacts the water. The tape is raised and lowered slowly until the exact point of contact is located. While holding the tape on the MP, the depth to water below the MP is read from

Table 4. Applied correction factors for electric tapes YMP-1, YMP-2, YMP-5, and YMP-6

$[--$, no measurements made for given depth-to-water range during period specified]

\begin{tabular}{|c|c|c|c|c|c|c|}
\hline \multirow{2}{*}{ Tape } & \multicolumn{2}{|c|}{$\begin{array}{l}\text { Measurement } \\
\text { period }\end{array}$} & \multicolumn{4}{|c|}{$\begin{array}{c}\text { Depth to water } \\
\text { (feet below measurement point) }\end{array}$} \\
\hline & Start & End & $\begin{array}{l}\text { Less than } \\
300 \text { feet }\end{array}$ & $300-400$ feet & $500-700$ feet & $\begin{array}{l}\text { Greater than } \\
700 \text { feet }\end{array}$ \\
\hline YMP-1 & $\begin{array}{l}11 / 08 / 93 \\
05 / 05 / 94\end{array}$ & $\begin{array}{l}05 / 05 / 94 \\
01 / 12 / 95\end{array}$ & -- & -- & -- & $\begin{array}{l}-0.63 \text { to }-0.80 \\
-.80\end{array}$ \\
\hline YMP-2 & $01 / 01 / 94$ & $12 / 31 / 94$ & -- & -- & -0.47 & -.47 \\
\hline YMP-5 & $\begin{array}{l}11 / 08 / 93 \\
05 / 05 / 94\end{array}$ & $\begin{array}{l}05 / 05 / 94 \\
01 / 18 / 95\end{array}$ & $\begin{array}{r}-0.02 \\
-.02\end{array}$ & $\begin{array}{r}0.04 \\
.04\end{array}$ & $\begin{array}{l}.17 \text { to } .25 \\
.25\end{array}$ & $\begin{array}{l}.29 \text { to } .43 \\
.43\end{array}$ \\
\hline YMP-6 & $01 / 01 / 94$ & $12 / 31 / 94$ & -.08 & -.08 & -.25 & -- \\
\hline
\end{tabular}


markings on the tape. At least one additional reading of depth to water is recorded for every measurement made with a calibrated electric tape to verify the initial reading. Supplemental measurements are made only if the two measured depths differ by more than $0.05 \mathrm{ft}$. If supplemental measurements indicate the difference is due to fluctuating water level, the measured depths and appropriate site status are recorded. An example of the calculation of depth to water below land surface, at a site, using USGS-EMP calibrated electric tape YMP-5 is shown below:

Location: JF-3

Date: June 28, 1994

Tape ID: YMP-5

Correction factor: $+\mathbf{0 . 4 3} \mathrm{ft}$ (for depths greater than $700 \mathrm{ft}$ )

\section{Depth belowMP} $712.05 \mathrm{ft}$

Correction factor

Corrected depth below MP

$+.43 \mathrm{ft}$

$712.48 \mathrm{ft}$

Height of MP above land surface

Depth to water below land surface

$\overline{710.21 \mathrm{ft}}$

\section{Steel Tape}

USGS-SCP personnel made water-level measurements using calibrated steel tapes at sites CF-2, JF-1, JF-2, JF-2a, J-13, J-11, and J-12. Descriptions of the steel tapes, applicable corrections, and procedures used by USGS-SCP for making steel-tape measurements are given by Robison and others (1988, p. 6-11), Gemmell (1990, p. 8-12), and O'Brien (1991, p. 8-13). USGSSCP steel-tape measurements were compiled from information provided by USGS-SCP (Michelle S. Boucher, U.S. Geological Survey, written communs., 1992-94). Corrected depth-below-MP measurements were provided by USGS-SCP personnel and converted to depth below land surface by USGS-EMP personnel by subtracting the height of the MP above land surface.

Water-level measurements at other sites were made by personnel from the USGS or U.S. Fish and Wildlife Service (USFWS) using 300- or 500-ft reeled steel tapes. General procedures for using $300-$ and $500-\mathrm{ft}$ reeled steel tapes are to (1) chalk the bottom section of the tape, (2) lower the tape into the well until part of the chalked section is below the water surface, (3) hold the tape on the MP and record the "hold" reading, (4) raise the end of the tape to the surface, observing the "cut" (the top of the wet part of the chalked tape), (5) record the reading of the cut, (6) calculate the depth to water below the MP by subtracting the "cut" reading from the

"hold" reading, and (7) calculate the depth to water below land surface by subtracting the height of the MP from the depth to water below MP.

USGS-EMP personnel maintain one 500-ft tape as a reference tape and use three field tapes ( $t w o$ 500-ft and one $300-\mathrm{ft}$ ) for routine measurements. All steel tapes are uniquely marked for identification purposes. The field tapes were checked against the reference tape at five sites during December 1992 at depths to water ranging from about 119 to $385 \mathrm{ft}$. All the steel-tape measurements were within $0.01 \mathrm{ft}$ of the reference tape; as a result, no correction factor was used for waterlevel measurements made with USGS-EMP steel tapes. At least one additional reading of the depth to water is recorded for every measurement to verify the initial reading. Supplemental measurements are made only if the two measured depths differ by more than $0.05 \mathrm{ft}$. If supplemental measurements indicate the difference is due to fluctuating water level, the measured depths and appropriate site status are recorded.

\section{Other}

Site JF-2a (UE-25p 1 PTH) was equipped with a pressure transducer in March 1985 as part of site-characterization studies (Luckey and others, 1993, p. 117). USGS-SCP personnel calibrate the pressure transducer, develop an equation to convert transducer voltage to depth to water below the MP, and record voltage of the transducer during each site visit. Owing to the small diameter of the access tubes, the transducer must be removed to provide access for measuring the water level with a steel tape. When a steel-tape measurement cannot be made, the depth to water can be computed using the USGS-SCP transducer voltage data and current conversion equation. Periodic water-level measurements at site JF-2a, indicated with method " $B$ " in table 5 , are computed using this procedure. Installation, calibration, and operation of pressure transducers by USGS-SCP are described by Luckey and others (1993, p. 14-21).

A water-level recorder, operated by the National Park Service (NPS), at site AM-4 (Devils Hole) records the depth to water below an installed measurement point. The daily mean water levels for each month with a complete record are used to compute a monthly average water level. The monthly average water levels are listed in table 5 as periodic water-level data for the 15 th of the month. 
Some water-level measurements were made by USFWS with uncalibrated electric tapes; the procedure used is similar to that for a calibrated electric tape, except measurements are not corrected on the basis of comparisons to reference steel tapes.

Site AM-4 (Devils Hole) has a small metal bolt fastened to the south wall of the fissure; the bolt is the measurement point and depth-to-water below the MP is measured with a ruled tape by USGS-EMP personnel.

Methods of water-level measurement were not specified for some data provided by the Nevada Division of Water Resources. Measurements made using unknown methods are indicated by ' $\mathrm{Z}$ " in table 5 .

\section{Continual Water-Level Data}

Two sites, JF-3 and AD-6, are instrumented by USGS-EMP to continually record ground-water level, atmospheric pressure, and battery voltage at 15-minute intervals. Instrumentation includes a gaged (vented) pressure sensor installed below the water surface, a barometer, and a data logger. Recorded data are processed to produce data on continual di pth to water, atmospheric pressure, battery voltage, and daily average depth to water.

The pressure sensors at sites JF-3 and AD-6 transmit data to the data logger in pounds per square inch, which varies with the height of the water above the sensor. The range of output is 0 to $5.000 \mathrm{lb} / \mathrm{in}^{2}$, which corresponds to a theoretical range of 0 to $11.53 \mathrm{ft}$ of water above the pressure sensor. The general steps for installing and calibrating pressure sensors and processing pressure-sensor data are as follows:

1. Depth to water below MP is measured with a steel or calibrated electric tape and recorded. If a calibrated electric-tape measurement is made, a correction factor is applied. Depth to water below MP is used for pressure-sensor calibration, rather than depth to water below land surface, because a fixed point of reference is required.

2. The pressure-sensor cable is connected to a data logger and the sensor is lowered down the well until a substantial change in readings indicates the water surface has been reached. These readings are recorded in the data logger and on a field sheet.

3. The sensor is lowered to a set point and the pressure-sensor readings are recorded after the senso: equilibrates. The set-point depth of the sensor is determined by adding the depth-to-water measurement to the depth at which the sensor is installed below the water surface. For example, if the depth-to-water is $710 \mathrm{ft}$ b slow the MP and the sensor is installed $5 \mathrm{ft}$ below the water surface, the set-point depth is $715 \mathrm{ft}$. The sensor cable is marked or tagged at the MP. This mark or tag is used for making measurements when the pressure sensor is raised or lowered.

4. Following installation the sensor is calibrated by simulating depths to water. Depth to water below MP is simulated by raising and lowering the pressure sensor. Raising the sensor $1 \mathrm{ft}$ above the set point will decrease the amount of submergence of the pressure sensor by $1 \mathrm{ft}$, thereby simulating a $1 \mathrm{ft}$ increase in depth to water. For example, if the depth to water is 710 $\mathrm{ft}$ below the MP (step 1) and the sensor is raised $1 \mathrm{ft}$ the simulated depth to water below the MP would be $711 \mathrm{ft}$ $(710+1=711 \mathrm{ft})$. Lowering the sensor $1 \mathrm{ft}$ below the set point will increase the amount of submergence of the pressure sensor by $1 \mathrm{ft}$, thereby simulating a $1 \mathrm{ft}$ decrease in depth to water. If the depth to water is $710 \mathrm{ft}$ below the MP and the sensor is lowered $1 \mathrm{ft}$, the simulated depth to water below the MP would be $709 \mathrm{ft}$ (710-1=709 ft).

The sensor is raised and lowered at 1/2-, 1-, or $2-\mathrm{ft}$ intervals above or below the set point. The tag or marking placed on the sensor cable at the set point (step 3) provides a reference for measuring the distance the sensor is raised or lowered. After the sensor output has stabilized at each interval, the time, pressure readings from the data logger (in pounds per square inch), distance of sensor above or below the set point, and simulated depth to water are recorded. The sensor cable is marked or tagged at the measured intervals and used for calibration checks. The sensor is raised and lowered for a range of depths that spans the anticipated range of water-level fluctuation.

5. Upon completion of pressure-sensor calibration the sensor is returned to the set point and the time and pressure readings from the data logger are recorded. Another water-level measurement is made with a steel or calibrated-electric tape and recorded to check for fluctuation of the water level during installation or calibration of the sensor.

6. Data recorded while calibrating the sensor are used to develop a regression equation to convert pressure readings to water level below MP. The pressure readings from the data logger and corresponding simulated depths below the MP are regressed using pressure 
(in pounds per square inch) as the independent variable and depth below the MP (in feet) as the dependent variable.

Water-level measurements are made with a steel or calibrated-electric tape when a continual monitoring site is visited. The pressure-sensor reading is recorded at the time of the measurement. The reading is converted to depth to water, using the established regression equation, and recorded as predicted water level. The steel tape or calibrated electric tape water-level measurements are used as reference measurements and are compared to the predicted value. Any difference between the reference measurement and predicted value is applied as a correction to the continual record by linearly prorating the difference with time between consecutive visits to account for drift in pressure-sensor output.

Data are periodically retrieved from the data logger using a portable computer, transferred to the USGS National Water-Information System (NWIS), and processed using data-base programs to store pressure-sensor, barometer, and battery data. The pressure-sensor data are converted to depth below land surface and stored. Daily average values are computed from the continual data and stored in the data base. Daily average depth-to-water values are used to compute daily average water-level altitudes, which also are stored in the data base.

\section{Pressure-Sensor System at Site JF-3}

Instrumentation is installed at JF-3 to continually collect water-level data every 15 minutes. Equipment was calibrated on November 8, 1993, and a regression equation was developed: depth to water below land surface $=(-2.741 \times$ pressure reading $)+716.507$. This equation is used to convert pressure readings stored in the data base to depth to water below land surface. Differences between reference measurements made with calibrated electric tapes and predicted water levels based on conversion of pressure readings ranged from $-0.06 \mathrm{ft}$ (January 6, 1994) to $0.02 \mathrm{ft}$ (January 20, 1994). The transducer failed on February 27, 1994. A new transducer was installed and calibrated on March 29, 1994. A new regression equation was developed: depth to water below land surface $=(-2.333 \times$ pressure reading $)+715.310$. Differences between reference measurements made with calibrated electric tapes and the predicted water levels, using the new regression equa- tion, ranged from $0.00 \mathrm{ft}$ (March 29, 1994) to $-0.22 \mathrm{ft}$ (June 22, 1994). On November 12, 1994, the transducer failed and was replaced January 18, 1995.

Depth-to-water measurements made with calibrated electric tapes during 1994 ranged from $709.95 \mathrm{ft}$ (May 26) to $710.44 \mathrm{ft}$ (October 19) below land surface. The daily average water-levels (table 6) ranged from $709.71 \mathrm{ft}$ (February 17) to $710.70 \mathrm{ft}$ (February 12) below land surface.

\section{Pressure-Sensor System at Site AD-6}

Instrumentation is installed at AD-6 to continually collect water-level data every 15 minutes. Equipment was calibrated on November 9, 1993, and a regression equation was developed: depth to water below land surface $=(-2.340 \times$ pressure reading $)+46.731$. This equation is used to convert pressure readings stored in the data base to depth to water below land surface. Differences between reference measurements made with reeled steel tapes and predicted water levels based on conversion of pressure readings ranged from $-0.10 \mathrm{ft}$ (August 12, 1994) to $0.01 \mathrm{ft}$ (October 6, 1994). No other calibrations were made in 1994.

Depth-to-water measurements made with calibrated electric or reeled steel tapes during 1994 ranged from $41.38 \mathrm{ft}$ (March 22) to $41.65 \mathrm{ft}$ (July 20) below land surface. The daily average water levels (table 7) ranged from $41.37 \mathrm{ft}$ (February 17) to $41.78 \mathrm{ft}$ (February 12 and November 22) below land surface.

\section{Other}

Five monitoring sites also are instrumented to continually collect water-level data as part of other programs; that data are collected, processed, and reviewed by personnel associated with other programs and can be obtained from principal investigators for those programs. Sites JF-2 and JF-2a were instrumented by USGS-SCP personnel. Sites RV-1, AM-5, and AM-7 were instrumented as part of the USGS-Hydrologic Resources Management and Environmental Restoration Programs.

\section{Ground-Water Discharge Data}

Measurements of ground-water discharge were collected and compiled for five springs and one flowing well. Four of the sites, AM-1a, AM-2, AM-5a, and 
AM-8, are in the Ash Meadows spring-discharge area of the Amargosa Desert. The other two sites, DV- 1 and DV-2, are in Death Valley.

Discharge measurements were made by NPS, USFWS, and USGS. Periodic or monthly mean discharge data were determined by the use of current meters, flumes, and volumetric techniques. The most commonly used method for measuring discharge was the vertical-axis current meter. This method is used to determine the average velocity of a partial section within a channel cross section. The average velocity of the partial section times the area of the partial section equals discharge of the section. The summation of the discharges for all the partial sections is the total discharge in the channel. This method is described in more detail by Buchanan and Somers (1969).

Some instantaneous discharge values were determined by measuring the depth of water inside a flume. This depth, or stage, is compared to an applicable stage-discharge relation for the flume to determine discharge. Where a continuous-recording instrument has been installed on a flume, monthly mean discharges can be computed from data collected and processed for an extended period. This method wąs used for site DV-1, where monthly mean discharge was computed only for months with complete data and reported for the 15th of the month. Determining discharges by the use of flumes is further described by Kilpatrick and Schneider (1983).

The volumetric method was used for measuring ground-water discharge from sites AM-2 and DV-2. A container with markings indicating known volumes was used to collect all discharge from the site while a stopwatch was used to determine the amount of time the discharge was collected. The container was positioned to collect the discharge and the stopwatch was started simultaneously. The container was removed, before it was overfilled, and the stopwatch was stopped simultaneously. The volume collected and elapsed time were recorded. The discharge rate is the volume collected divided by the time. This procedure was repeated three times and an average rate was computed for each site visit.

The accuracy of the methods is directly related to the operational conditions of the equipment used and to the environmental conditions in which the equipment operated. Discharge values are reported to two significant figures. Discharge determined by all methods ranged from $1.3 \mathrm{gal} / \mathrm{min}$ at site $\mathrm{DV}-2$ to $2,700 \mathrm{gal} / \mathrm{min}$ at site AM-5a for 1994 (table 8).

\section{Ground-Water Withdrawal Data}

Ground-water withdrawals were estimated from compiled data and are listed in table 9. Withdrawal data were supplied by public agencies including USDOE, USGS, and the Nevada Division of Water Resources (NDWR), and private organizations including Reynolds Electrical and Engineering Company (REECo) and SAGA Exploration Company. Estimated annual ground-water withdrawals are based solely on available data. Estimates for some years, therefore, reflect a lack of information for an entire area or underestimate total withdrawals within an area.

\section{Withdrawals from Alkali Flat-Furnace Creek Ranch Ground-Water Subbasin}

Withdrawals from the part of the Amargosa Desert within the subbasin were recompiled from groundwater pumpage inventories taken by NDWR. The pumpage inventories were for the entire Amargosa Desert hydrographic area during 1994, and include estimated withdrawals for irrigation, mining, industrial, commercial, and quasi-municipal and domestic use. All reported withdrawals for irrigation, mining, industrial, and commercial use are from the Alkali FlatFurnace Creek Ranch ground-water subbasin. All quasi-municipal and domestic use for the Amargosa Desert is included in the subbasin because data were not available to exclude the amount used in the Ash Meadows ground-water subbasin.

Withdrawals from Crater Flat were determined from totalizing flowmeters at site CF-2, site CF-3, and well USW VH-2 (which is located about 1.5 miles northwest of site CF-2). Withdrawals from site CF-2 are on the basis of quarterly pumpage reports provided by USDOE (Wendy Dixon, U.S. Department of Energy, written communs., 1994 and 1995). Withdrawals from site CF-3 were recompiled from flowmeter readings recorded by USGS-EMP personnel. Withdrawals from well USW VH-2 were recompiled from flowmeter readings and information supplied by SAGA Exploration Corporation for May 1991 to July 1993 and January to December 1994 (Charles Stevens, Mine Manager, written communs., 1993 and 1995). Withdrawals from Crater Flat for 1991 through 1993 have been revised from those listed in La Camera and Westenburg (1994) and Hale and Westenburg (1995) on the basis of data for well USW VH-2, which became available subsequent to publication of those reports. 
Withdrawals from Jackass Flats were recompiled from flowmeter readings supplied by REECo for sites J-12 and J-13 (David B. Wood, U.S. Geological Survey, written commun., 1995). Withdrawals from Rock Valley are considered negligible on the basis of knowledge of activities in that area.

\section{Withdrawals from Ash Meadows Ground-Water Subbasin}

Withdrawals from Mercury Valley were recompiled from flowmeter readings supplied by REECo for site MV-1 (David B. Wood, U.S. Geological Survey, written commun., 1995). Withdrawals for quasimunicipal and domestic use from the part of the Amargosa Desert within the subbasin were not available, although ground water is known to have been pumped in 1994.

\section{Quality Assurance}

Stringent quality assurance is required for all work pertaining to Yucca Mountain studies to establish adequate confidence in the reliability of data collection, processing, and reporting. In the context of this datacollection program, quality assurance is defined as all planned or systematic actions designed to provide data and records of a desired quality. A variety of qualitycontrol procedures, which are the operational techniques and activities used to meet the required quality objectives, have been implemented.

The numerous management and administrative procedures that control processing, record keeping, and reporting of data by USGS-EMP are not detailed in this report. Generally, data such as location, date and time of measurements, and field measurements are recorded onsite. Those data are reviewed for completeness and accuracy, stored in project files and data bases, and are subsequently included in publications by the USGS. Following publication, data are stored in a comprehensive record-keeping facility maintained by contractors for USDOE.

In addition to standard USGS practices and the procedures previously described, formal unpublished technical procedures associated with the Yucca Mountain Site Characterization Project have been developed for the collection of water-level and discharge data. Those technical procedures include equipment tests and calibrations, in addition to measurement tech- niques, to ensure that necessary and expected precision and accuracy are attained. The principal technical procedures that control the collection of data by project personnel are listed by La Camera and Westenburg (1994, p. 17).

\section{PRESENTATION OF GROUND-WATER DATA}

Tables included in this report generally list only 1994 ground-water data, whereas the figures show data for the period of record to illustrate changes in groundwater resources through time. Exceptions are tables 3, 4, 9, and 10; these tables include ciata from 1993 and 1995 used to determine correction factors for electrictape measurements made during 1994, revised data for historical ground-water withdrawals from Crater Flat (on the basis of information which was previously unavailable), and a summary of historical water-level measurements in Jackass Flats. Below is a description of the content of the tables and figures presented in this report.

Tables 5-9 list ground-water data that have been collected and compiled in the Yucca Mountain region as part of this study; they are included at the back of this report. Figures 1-13 are hydrographs and other graphical representations of selected data from the tables in this report, La Camera and Westenburg (1994), Hale and Westenburg (1995), and data collected by USGS-SCP.

Pumping of water from or injecting water into a well or nearby well may cause transient water levels that differ from long-term or sustained ground-water levels. Observations about such activities (noted by field personnel during site visits) and corresponding water levels, which may represent transient conditions, are included in data tables. Those data, however, are excluded from the figures showing variations in water level over time.

Table 5 lists periodic measurements of depth to water and water-level altitude at 36 sites (including a flowing well) for 1994. Periodically collected data generally are from manual onsite measurements of depth to water. Data at site AM-4 (Devils Hole) reported as data source "NPS," however, are monthly average water levels and are based on continual water levels recorded by instrumentation at the site. Data collected by other agencies or programs are subject to revision upon further review by that agency or program. 
Figures 1-4 show water-level altitude listed in this report and previous reports on selected ground-water data for the Yucca Mountain region. Data for wells with primary contributing units of carbonate rock, volcanic rock, valley fill, and undifferentiated sedimentary rock are presented.

Tables 6 and 7 list measurements of daily average water levels at sites JF-3 and AD-6, respectively for 1994. The daily average water levels are based on continually collected data at the sites, which are measurements of water levels recorded by instrumentation at 15-minute intervals.

Figures 5 and 6 show measurements of daily average depth to water and water-level altitude on the basis of continually collected data listed in tables 6 and 7 of this report, La Camera and Westenburg (1994), and Hale and Westenburg (1995) for sites JF-3 and AD-6, respectively. Data is presented for 1992 through 1994.

Table 8 lists periodic measurements of groundwater discharge at six sites for 1994. The data for site DV-1 (Texas Spring), reported as data source "NPS," represent monthly average discharge for each month with a complete record.

Figure 7 shows measurements of ground-water discharge at sites AM-1a, AM-5a, and AM-8 through 1994 , as listed in this report and previous reports on selected ground-water data for the Yucca Mountain region. Figures 8 and 9 show measurements of ground-water discharge at sites AM-2 and DV-2, and DV-1, through 1994, respectively, listed in this report and previous reports on selected ground-water data for the Yucca Mountain region.

Table 9 shows estimates of annual ground-water withdrawals from wells in the Yucca Mountain region for 1994. Also included are revised estimates of withdrawals from Crater Flat (on the basis of previously unavailable information) as presented in La Camera and Westenburg (1994) and Hale and Westenburg (1995) for calendar years, 1991-93. Estimated annual ground-water withdrawals are based solely on available data. Ground-water withdrawals, in millions of gallons and in acre-feet, from water-supply wells are grouped by ground-water subbasin and totaled by hydrographic area (or part of a hydrographic area) for calendar year 1994.

Figures 10 and 11 show estimates of annual ground-water withdrawals listed in this and previous reports on selected ground-water data for the Yucca Mountain region. Shown are withdrawals for areas with available data within the Alkali Flat-Furnace Creek Ranch and Ash Meadows ground-water subbasins, respectively, through 1994.

\section{DISCUSSION OF GROUND-WATER LEVELS AND GROUND-WATER WITHDRAWALS IN JACKASS FLATS}

In Jackass Flats, ground water is withdrawn to support several USDOE activities (including site characterization); if those withdrawals affect ground-water levels, the effects may be detected in Jackass Flats before they are detected elsewhere within the Yucca Mountain region. Therefore, the following section discusses data on ground-water levels and ground-water withdrawals in Jackass Flats. Changes in water-level altitudes at a particular site through time, discussed in the text towards the end of this section, are described in an order generally corresponding to increasing distance of the site from water-supply wells $\mathrm{J}-13$ and $\mathrm{J}-12$.

Figure 12 shows water-level altitudes for seven wells in Jackass Flats and estimated annual groundwater withdrawals in Jackass Flats from 1983 through 1994. Prior to 1983 , data on ground-water withdrawals in Jackass Flats generally represent only the withdrawals from well J-12 rather than total withdrawals from Jackass Flats. For greater consistency and comparability of data on water-level altitudes, water levels in wells $\mathrm{J}-13, \mathrm{~J}-12$, and JF-3 that may have been affected by pumping or recent pumping of the well are excluded from figure 12.

Water-level altitudes presented are based on discrete measurements or daily average water levels (when continual data recorded by instrumentation were available for more than half the year). Water levels based on discrete measurements made during site visits are shown for all sites prior to 1985 ; sites JF-1, JF-2 (in 1994), J-13, J-11, and J-12 since 1985; and site JF-3 prior to May 1992. Daily average water levels from USGS-SCP (R.P. Graves, U.S. Geological Survey, written commun., 1995) are shown for sites JF-2 for 1985 through 1993 and JF-2a for 1985 through 1994; continual data collection at site JF-2 was discontinued in June 1994 and daily water levels were consequently available for less than half the year. Daily average water levels also are shown for site JF-3 from May 1992 through December 1994; long-term monitoring and continual data collection at this site began in May 1992. 
Ground-water withdrawals consist of combined pumpage from water-supply wells J-13 and J-12. Withdrawals from 1983 through 1994 are from data presented in this and previous reports on selected ground-water data for the Yucca Mountain region.

Total 1994 withdrawal in Jackass Flats was about $90 \mathrm{Mgal}$, an increase of about $23 \mathrm{Mgal}$ (34 percent) from 1993. Median annual ground-water withdrawal in Jackass Flats was about $52 \mathrm{Mgal} / \mathrm{yr}$ for 1983 through 1991 (La Camera and Westenburg, 1994, p. 30). Compared to the median withdrawal for 1983 through 1991, total withdrawals in Jackass Flats decreased about 25 percent in 1.992 and increased about 29 percent and 73 percent in 1993 and 1994, respectively.

Table 10 lists selected statistics, derived from data shown in figure 12, for water-level altitudes in Jackass Flats. Data for wells JF-1, JF-2, JF-2a, J-13, J-11, J-12, and JF-3 are summarized for the selected baseline periods and for calendar years 1992 through 1994. For well JF-3, completed in January 1992, statistical data for measurements during the baseline period also are listed to provide additional information. The table shows the number of measurements; the minimum, maximum, and median water-level altitude; and the average deviation of measured water-levels about the median water level for each period. Because of the recent availability of daily average water levels for wells JF-2 and JF-2a, summary statistics based on discrete water-level measurements listed by La Camera and Westenburg (1994) and Hale and Westenburg (1995) have been revised.

To minimize effects of variability in measurement frequency on median water-level altitudes calculated for the period prior to 1992, the selection of a baseline period for each site was based on (1) the maximum number of consecutive years (including 1991) for which water-level measurements are available and (2) consecutive years containing approximately similar frequencies of water-level measurement. For consistency, the baseline period selected at instrumented wells JF-2 and JF-2a was the period following installation of continual recorders. The baseline period for JF-3 was based solely on the availability of daily average water levels from the continual data recorder, which was installed in May 1992. These baseline periods will be the standard to which the following years will be compared.

The median water-level altitudes shown in table 10 indicate a statistically representative ground-water level for a particular time period. The median of waterlevel measurements is listed because the calculated median is less affected by a few high or low values than the arithmetic mean. When more than half a year of continual data at a site are available (recorded hourly or more frequently by instrumentation), the median of daily average water levels is listed.

The average deviation indicates the variability of the individual measurements about the median and how precisely the median approximates a typical water-level altitude during the period. It equals the sum of the absolute differences between individual measurements and the median, divided by the number of individual measurements.

Median water-level altitude in water-supply well $\mathrm{J}-13$ is $2,390.0 \mathrm{ft}$ above sea level for the baseline period (table 10). Median water-level altitude in well J-13 for 1994 is $2,389.7 \mathrm{ft}$, which is $0.3 \mathrm{ft}$ lower than that for the baseline period. The amount of change in median water-level altitudes between the two periods is greater than the average deviation for the baseline period and that for 1994. Median water-level altitude in 1994 also is $0.2 \mathrm{ft}$ lower than that for 1993. Continued monitoring of ground-water withdrawals in Jackass Flats and water levels at this site should indicate whether the apparent decline in median water level continues while withdrawals from water supply wells in the area increase (figure 12).

Median water-level altitude in water-supply well $\mathrm{J}-12$ is $2,388.3 \mathrm{ft}$ above sea level for the baseline period. Median water-level altitude in well $\mathrm{J}-12$ for 1994 is $2,388.2 \mathrm{ft}$, which is $0.1 \mathrm{ft}$ lower than that for the baseline period. The amount of change in median water-level altitudes is equal to the average deviation of water levels for the baseline period, but less than that for 1994. Median water-level altitude in 1994 also is $0.1 \mathrm{ft}$ lower than that for 1993 .

Median water-level altitude in well JF-3, which is $0.5 \mathrm{mi}$ south of water-supply well $\mathrm{J}-12$ and penetrates volcanic rock, is $2388.3 \mathrm{ft}$ above sea level for the baseline period. Median water-level altitude in well JF-3 for 1994 is $2,388.1 \mathrm{ft}$, which is $0.2 \mathrm{ft}$ lower than that for the baseline period. The amount of change in median water-level altitudes is greater than the average deviation for the baseline period and that for 1994. Median water-level altitude in 1994 also is $0.2 \mathrm{ft}$ lower than that for 1993. Similar to well J-13, further monitoring at this site should indicate whether the apparent decline in water level continues.

Median water-level altitudes in wells JF- 1 and $\mathrm{JF}-2$, which are north of the water-supply wells and penetrate volcanic rock, are 2,392.5 and 2,392.1 ft 
above sea level, respectively, for the baseline period. Median water-level altitude in well JF-1 for 1994 is $2,392.3 \mathrm{ft}$, which is $0.2 \mathrm{ft}$ lower than that for the baseline period. The amount of change in median waterlevel altitudes is equal to the average deviation for the baseline period, and greater than that for 1994. Median water-level altitude in well JF-1 for 1994 also is $0.2 \mathrm{ft}$ lower than that for 1993. The median water-level altitude in well JF-2 for 1994 is $2,392.2 \mathrm{ft}$, which is $0.1 \mathrm{ft}$ higher than the median for the baseline period. This difference is less than the average deviation of waterlevels during the baseline period.

Median water-level altitude in well JF-2a, which is northwest of the supply wells and penetrates carbonate rock, is $2,468.6 \mathrm{ft}$ above sea level for the baseline period. Median water-level altitude in well JF-2a for 1994 is $2,469.0 \mathrm{ft}$ above sea level, which is $0.4 \mathrm{ft}$ higher than that for the baseline period. The difference in median water-level altitudes is equal to the average deviation for the baseline period and greater than the average deviation for 1994. Compared with data for most other wells summarized in table 10 , however, long-term changes in water levels that exceed variability inherent in the data are difficult to identify due to the high variability in measurements prior to 1993 . The median water-level altitude in JF-2a for 1994 is $0.2 \mathrm{ft}$ higher than that for 1993.

Median water-level altitude in well $\mathrm{J}-11$, which is east of water-supply wells $\mathrm{J}-13$ and $\mathrm{J}-12$ and penetrates volcanic rock, is $2,402.2 \mathrm{ft}$ above sea level for the baseline period. Median water-level altitude in well $\mathrm{J}-11$ for 1994 is $2,402.3 \mathrm{ft}$, which $0.1 \mathrm{ft}$ higher than that for the baseline period. The difference in median water-level altitudes is equal to the average deviation for the baseline period and for 1994.

Figure 13 shows the median water-level altitudes and the average deviation of the water levels for wells JF-1, JF-2, JF-2a, J-13, J-11, J-12, and JF-3 for baseline periods and for 1992 through 1994. Further monitoring at wells JF-1, J-13, J-12, and JF-3 should indicate whether declines in median water-level altitudes at those sites since 1993 represent short-term fluctuations in water levels or represent sustained decreases during periods of increased ground-water withdrawals at the supply wells in Jackass Flats.

\section{REFERENCES CITED}

Buchanan, T.J., and Somers, W.P., 1969, Discharge measurements at gaging stations: U.S. Geological Survey Techniques of Water-Resources Investigations, Book 3 , Chapter A8, $65 \mathrm{p}$.

Boucher, M.S., 1994, Water levels in wells J-11 and J-12, 1989-91, Yucca Mountain Area. Nevada: U.S. Geological Survey Open-File Report 94-303, 9 p.

Dudley, W.W., Jr., and Larson, J.D., 1976, Effect of irrigation pumping on desert pupfish habitats in Ash Meadows, Nye County, Nevada: U.S. Geological Survey Professional Paper 927, $52 \mathrm{p}$.

Fenneman, N.M, 1931, Physiography of western United States: New York, McGraw-Hill, 534 p.

Gemmell, J.M., 1990, Water levels in periodically measured wells in the Yucca Mountain area, Nevada, 1988: U.S. Geological Survey Open-File Report 90-113, 47 p.

Hale, G.S., and Westenburg, C.L., 1995, Selected groundwater data for Yucca Mountain region, southern Nevada and eastern California, calendar year 1993: U.S. Geological Survey Open-File Report 95-158, 67 p.

Harrill, J.R., Gates, J.S., and Thomas, J.M., 1988, Major ground-water flow systems in the Great Basin region of Nevada, Utah, and adjacent states: U.S. Geological Survey Hydrologic Investigations Atlas HA-694-C, 2 sheets.

Johnston, R.H., 1968, U.S. Geological Survey tracer study, Amargosa Desert, Nye County, Nevada, Part 1, Exploratory drilling, tracer well construction and testing, and preliminary findings: U.S. Geological Survey Report USGS-474-98, 64 p. Available only from National Technical Information Service, U.S. Department of Commerce, Springfield, VA 22161.

Kilpatrick, F.A., and Schneider, V.R., 1983, Use of flumes in measuring discharge: U.S. Geological Survey Techniques of Water-Resources Investigations, Book 3, Chap. A14, 46 p.

Kilroy, K.C., 1991, Ground-water conditions in Amargosa Desert, Nevada-California, 1952-87: U.S. Geological Survey Water-Resources Investigations Report 894101, $93 \mathrm{p}$.

La Camera, R.J., and Westenburg, C.L., 1994, Selected ground-water data for Yucca Mountain region, southern Nevada and eastern California, through December 1992: U.S. Geological Survey Open-File Report 94-54, $161 \mathrm{p}$.

Lobmeyer, D. H., Luckey, R.R., O'Brien, G.M., and Burkhardt, D.J., 1995, Water levels in continuously monitored wells in the Yucca Mountain area, Nevada, 1989: U.S. Geological Survey Open-File Report 93098, $173 \mathrm{p}$. 
Luckey, R.R., Lobmeyer, D.H., and Burkhardt, D.J., 1993, Water levels in continuously monitored wells in the Yucca Mountain area, Nevada, 1985-88: U.S. Geological Survey Open-File Report 91-493, 252 p.

McKinley, P.W., Long, M.P., and Benson, L.V., 1991, Chemical analysis of water from selected wells and springs in the Yucca Mountain area, Nevada and southeastern California: U.S. Geological Survey Open-File Report 90-355, $47 \mathrm{p}$.

O'Brien, G.M., 1991, Water levels in periodically measured wells in the Yucca Mountain area, Nevada, 1989: U.S. Geological Survey Open-File Report 91-178, 51 p.

1993, Earthquake-induced water-level fluctuations at Yucca Mountain, Nevada, June 1992: U.S. Geological Survey Open-File Report 93-73, 12 p.

O'Brien, G.M., Tucci, Patrick, and Burkhardt, D.J., 1995, Water levels in the Yucca Mountain area, Nevada, 1992; U.S. Geological Survey Open-File Report 94$311,74 \mathrm{p}$

Robison, J.H., 1984, Ground-water level data and preliminary potentiometric surface maps, Yucca Mountain and vicinity, Nye County, Nevada: U.S. Geological Survey Water-Resources Investigations Report 84-4197, 8 p.
Robison, J.H., Stephens, D.M., Luckey, R.R., and Baldwin, D.A., 1988, Water levels in periodically measured wells in the Yucca Mountain area, Nevada, 1981-87: U.S. Geological Survey Open-File Report 8*-468, 132 p.

Rush, F.E., 1968, Index of hydrographic areas in Nevada: Nevada Division of Water Resources, Information Report 6, $38 \mathrm{p}$.

Thordarson. William, Young, R.A., and Winograd, I.J., 1967, Records of wells and test holes in the Nevada Test Site and vicinity (through December 1966): U.S. Geological Survey Open-File Report TEI-872, 26 p.

Tucci, Patrick, Goemaat, R.L., and Burkhardt, D.J., in press a, Water levels in the Yucca Mountain area, Nevada, 1993: U.S. Geological Survey Open-File Report 95159.

Tucci, Patrick, O'Brien, G.M., and Burkhardt, D.J., in press b, Water levels in the Yucca Mountain area, Nevada, 1990-91: U.S. Geological Survey Open-File Report 94111.

Waddell, R.K., Robison, J.H., and Blankennagel, R.K., 1984, Hydrology of Yucca Mountain and vicinity, Nevada-California-Investigative results through mid1983: U.S. Geological Survey Water-Resources Investigations Report 84-4267, 72 p. 
BASIC DATA 


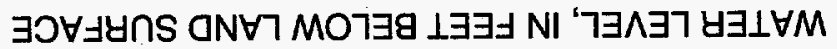

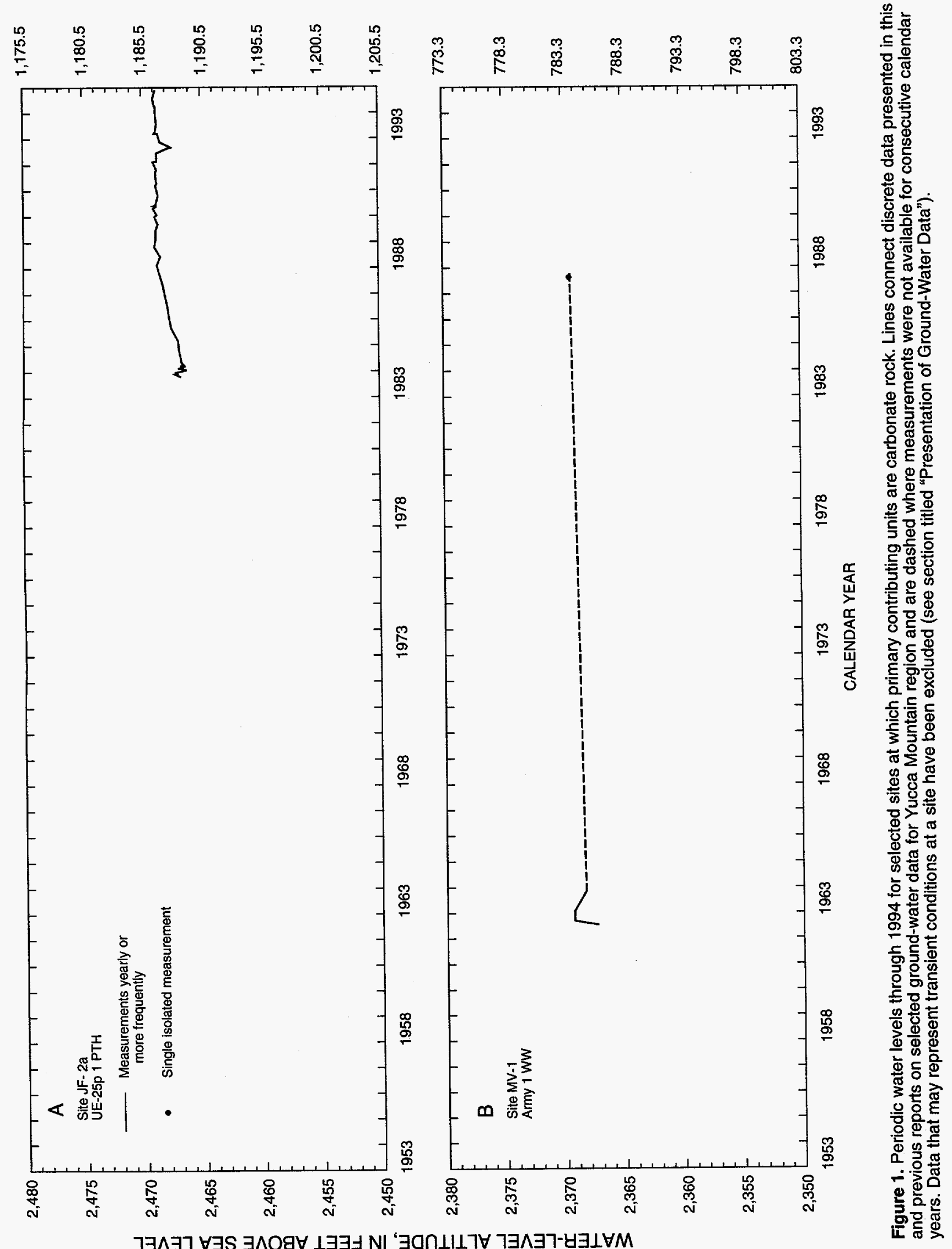

22 Selected Ground-Water Data for Yucca Mountain Region, Southern Nevada and Eastern California, Through December 1994 


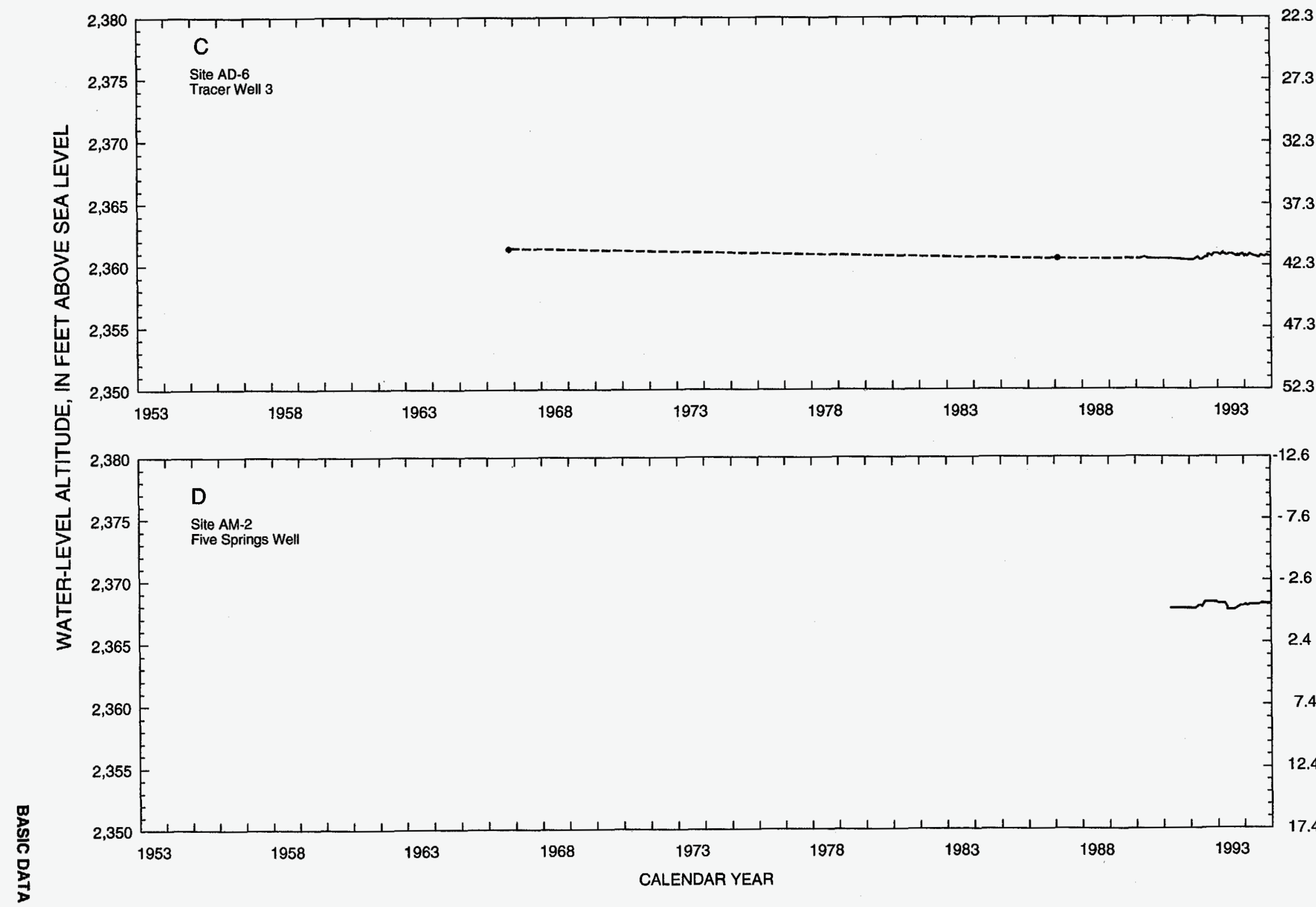

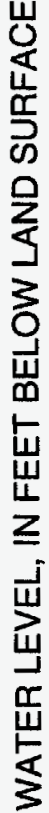

( Figure 1. Continued. 


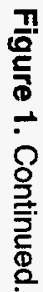
WATER-LEVEL ALTITUDE, IN FEET ABOVE SEA LEVEL

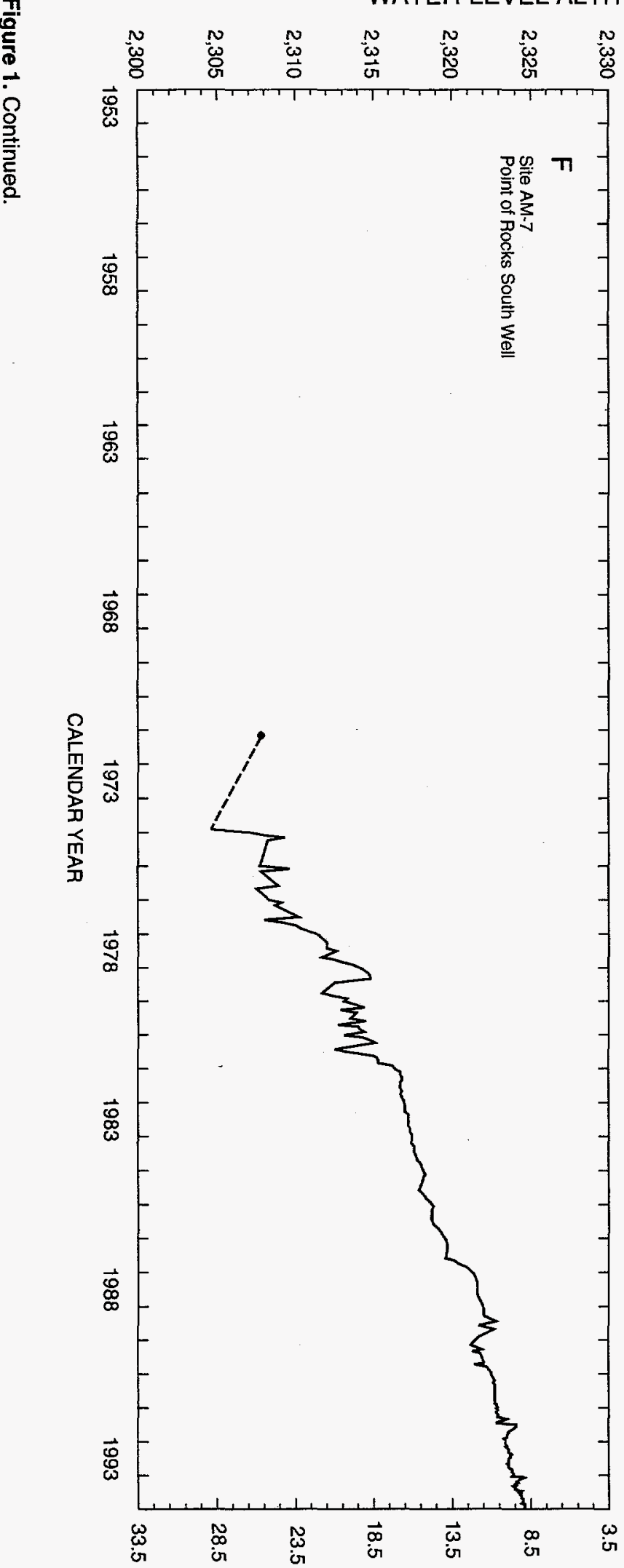

WATER LEVEL, IN FEET

BELOW LAND SURFACE

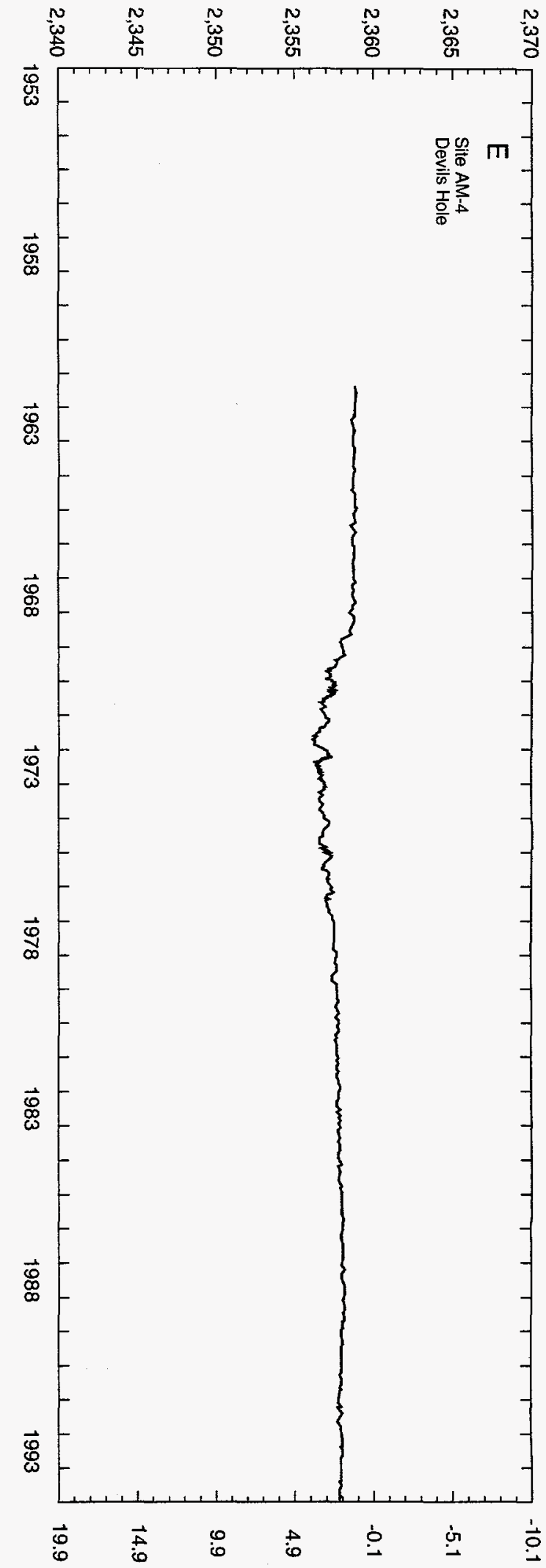


ํㅜㅇ

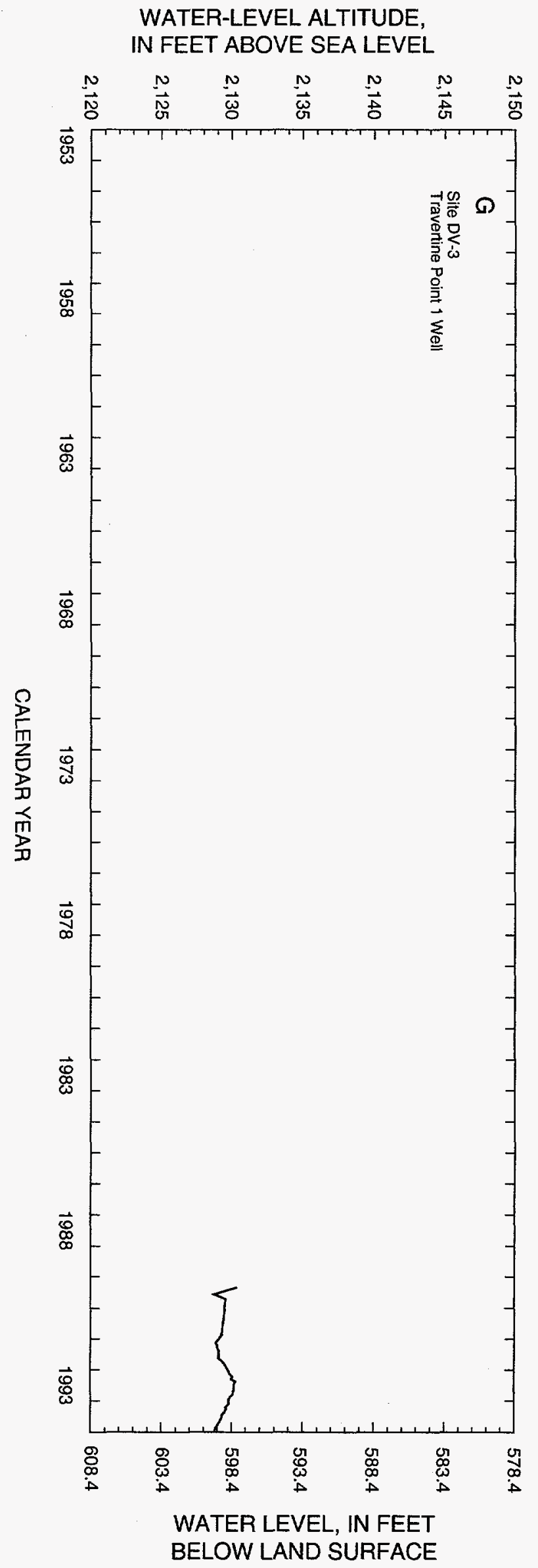




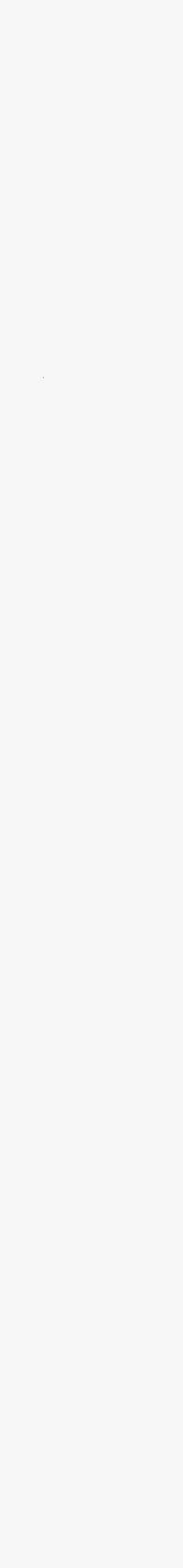

WATER-LEVEL ALTITUDE, IN FEET ABOVE SEA LEVEL
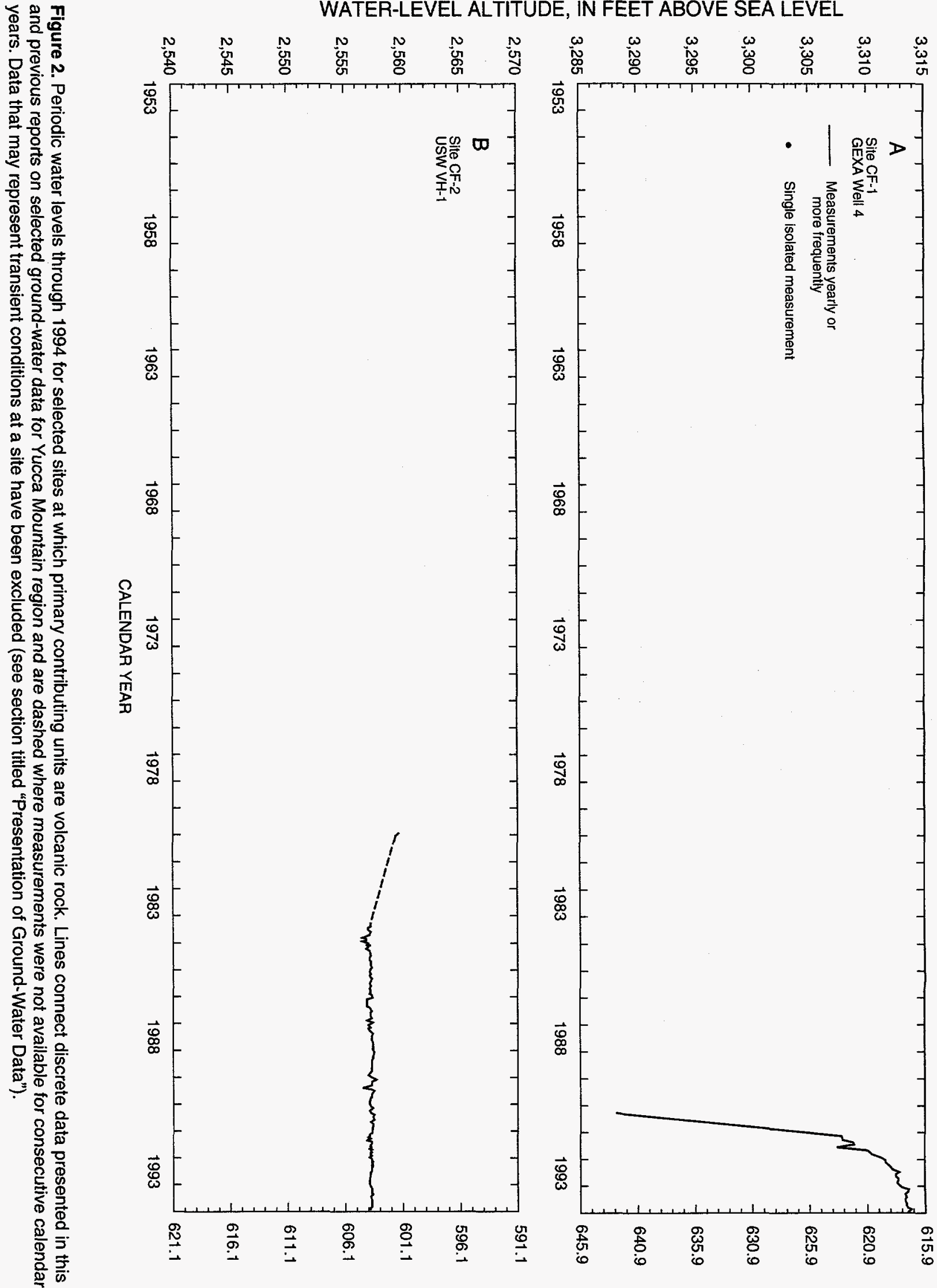

क्ष

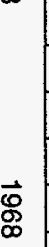

$\vec{\Phi}$

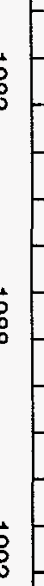

\&

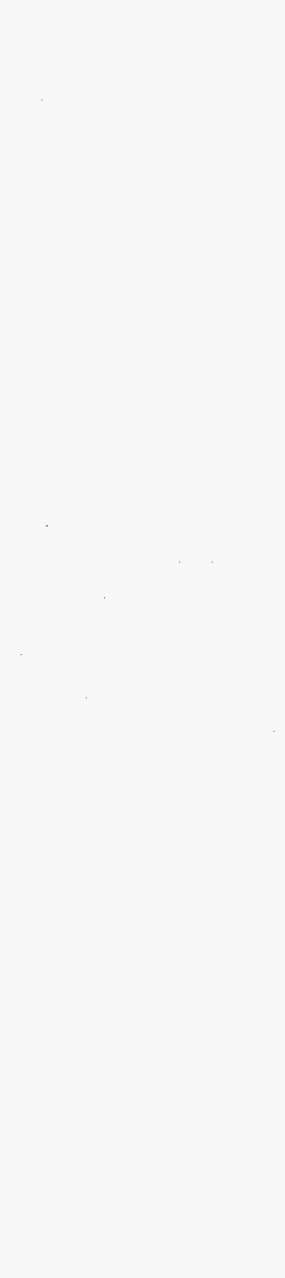

$\underset{\omega}{\omega}$ 


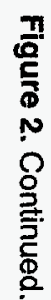

WATER-LEVEL ALTITUDE, IN FEET ABOVE SEA LEVEL

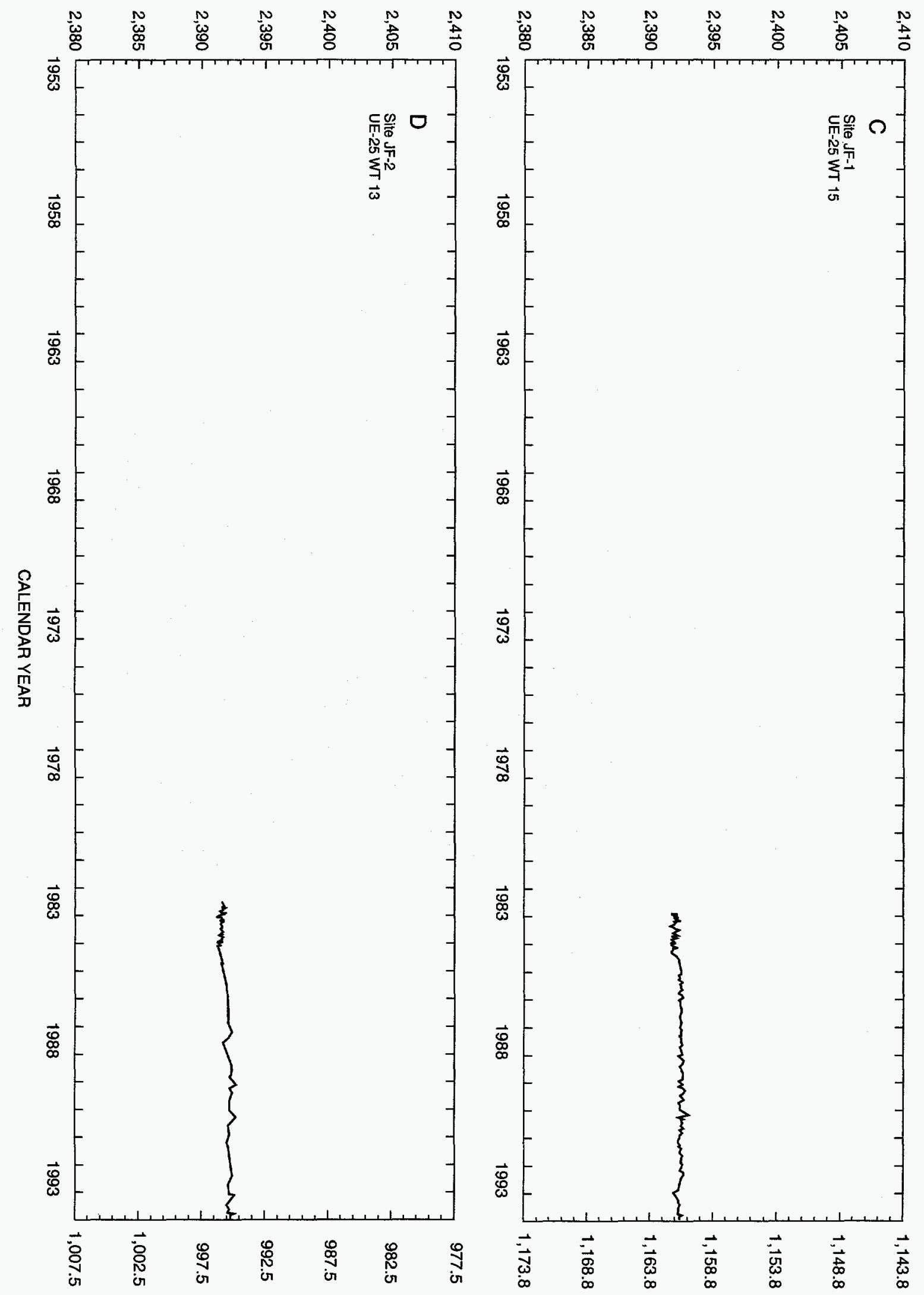

WATER LEVEL, IN FEET BELOW LAND SURFACE 
$\exists \supset \forall \exists y \cap S$ ดN

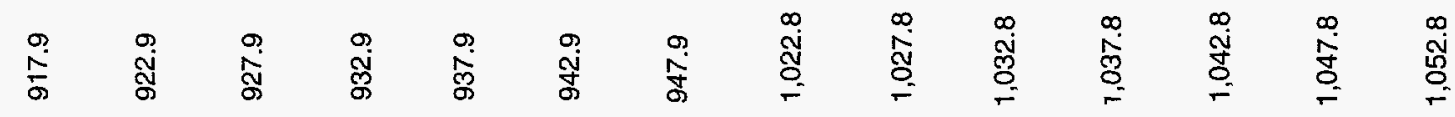

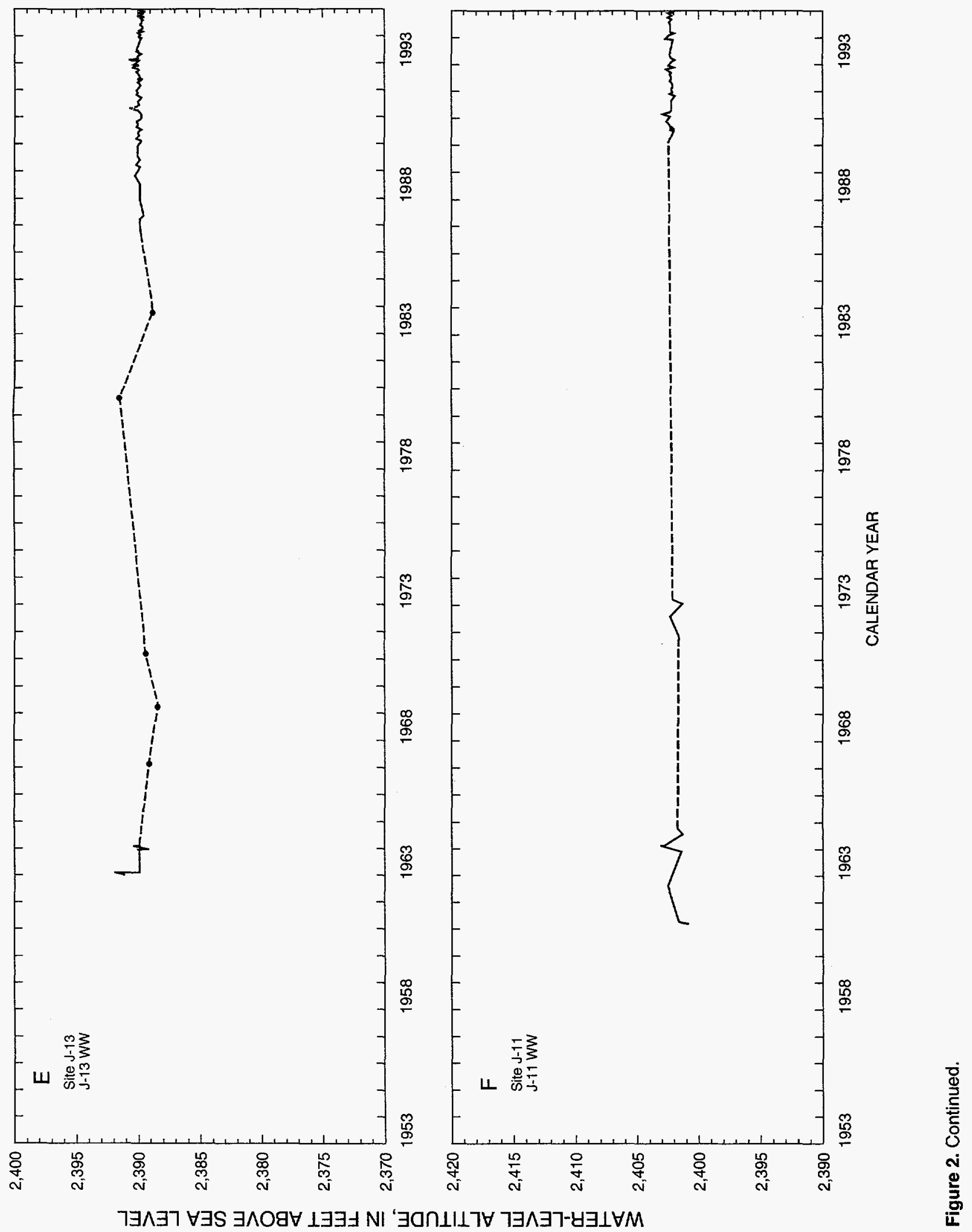




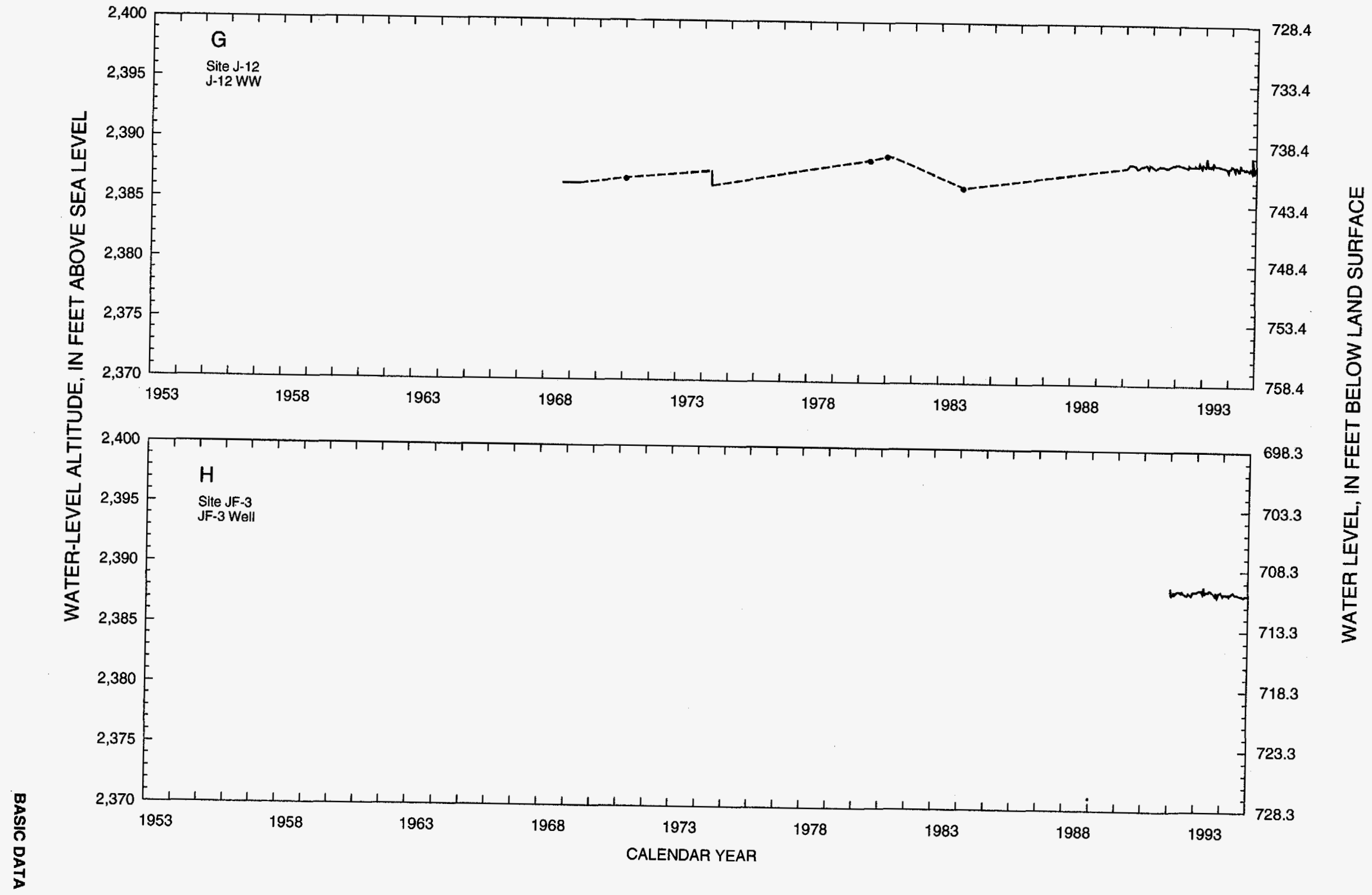

Figure 2. Continued. 

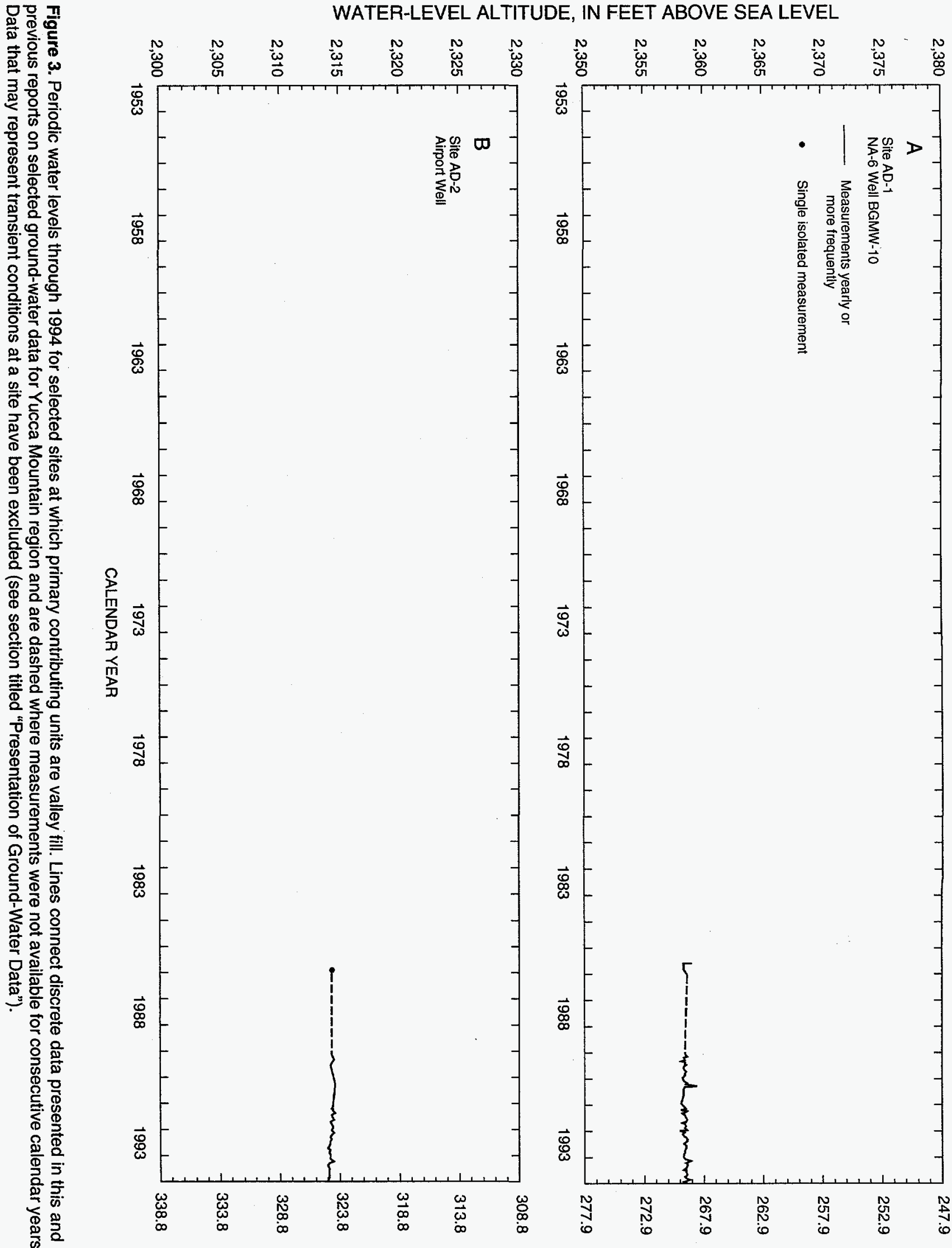

$\stackrel{Ð}{\infty}$

$\stackrel{\vec{\omega}}{\omega}$

$\overrightarrow{\mathrm{O}}$

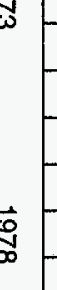

No

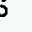
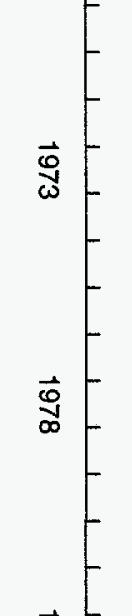

足

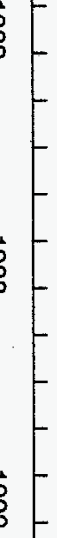

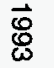

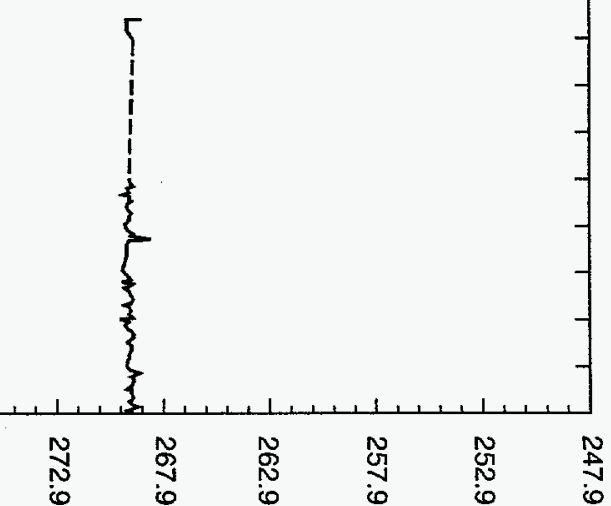

WATER LEVEL, IN FEET BELOW LAND SURFACE 


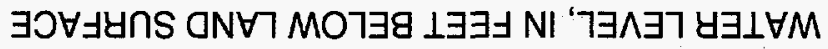

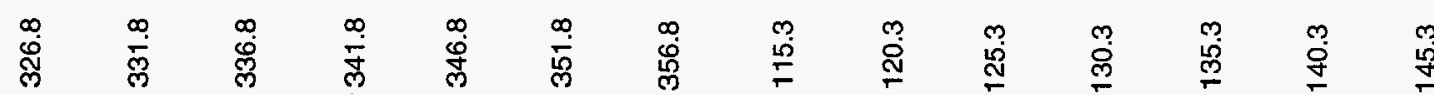

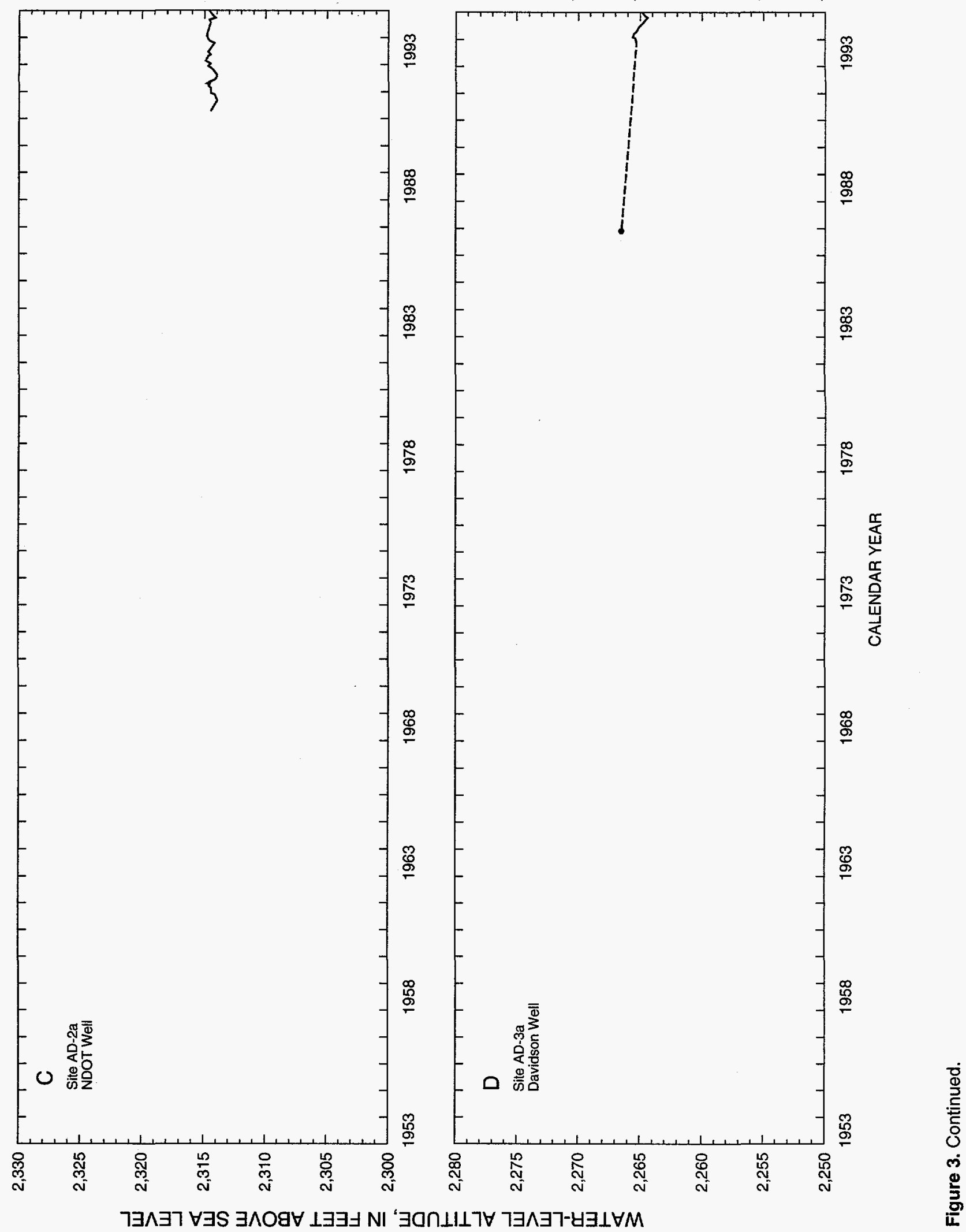




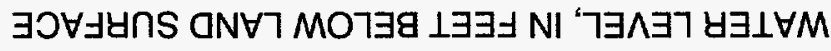

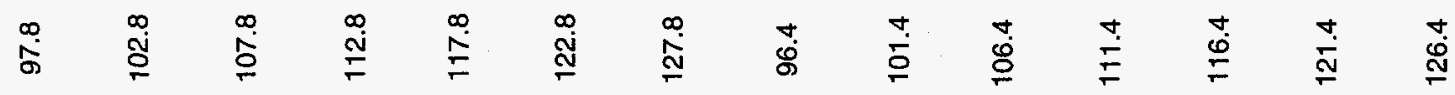

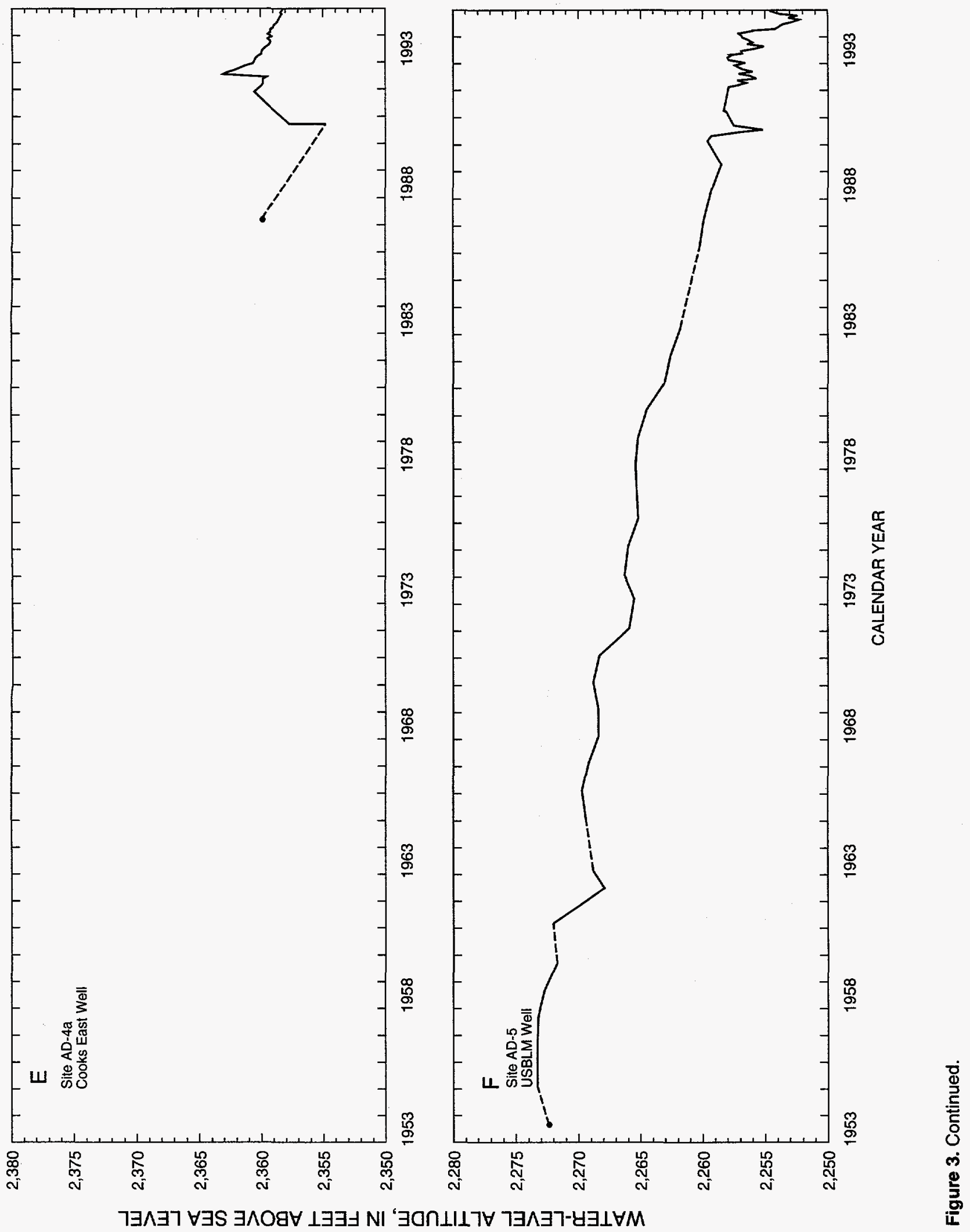




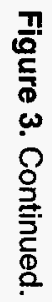

WATER-LEVEL ALTITUDE, IN FEET ABOVE SEA LEVEL

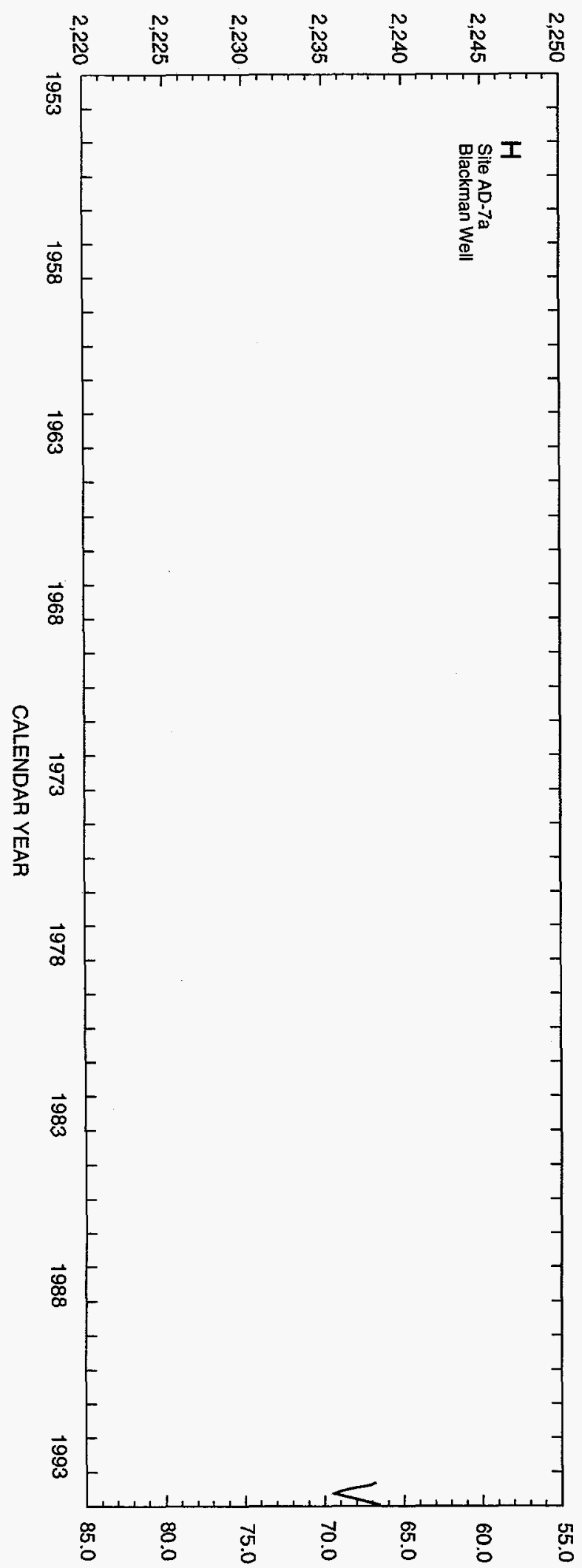

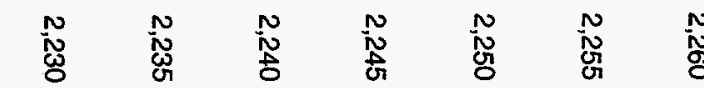

审

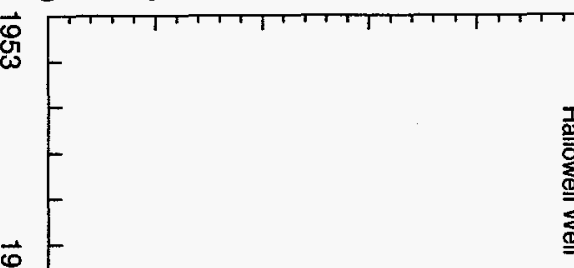

悹

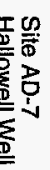

$\Omega$

$\vec{\circ}$

(1)
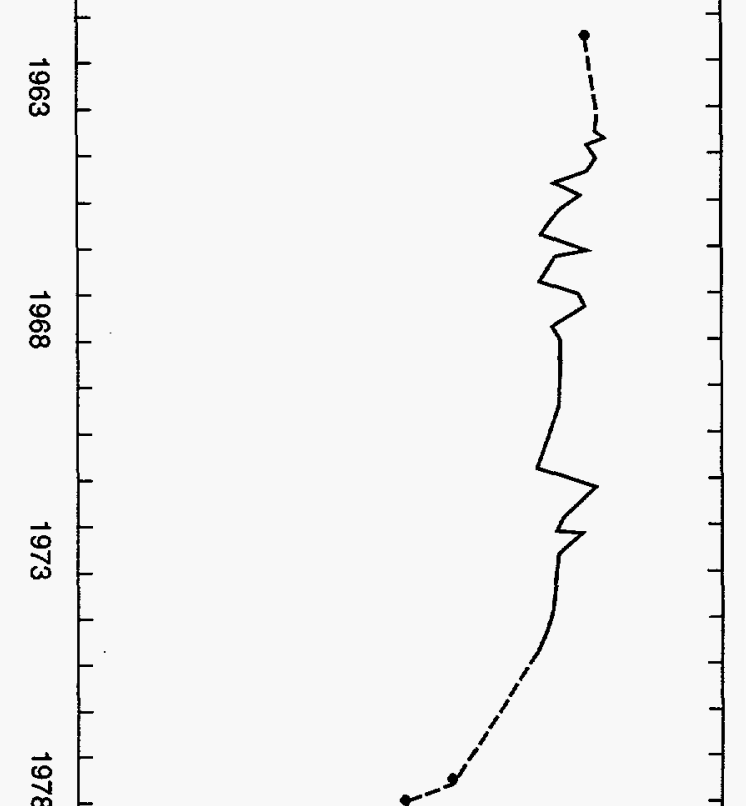

क्ष

$\overrightarrow{\mathscr{\varpi}}$
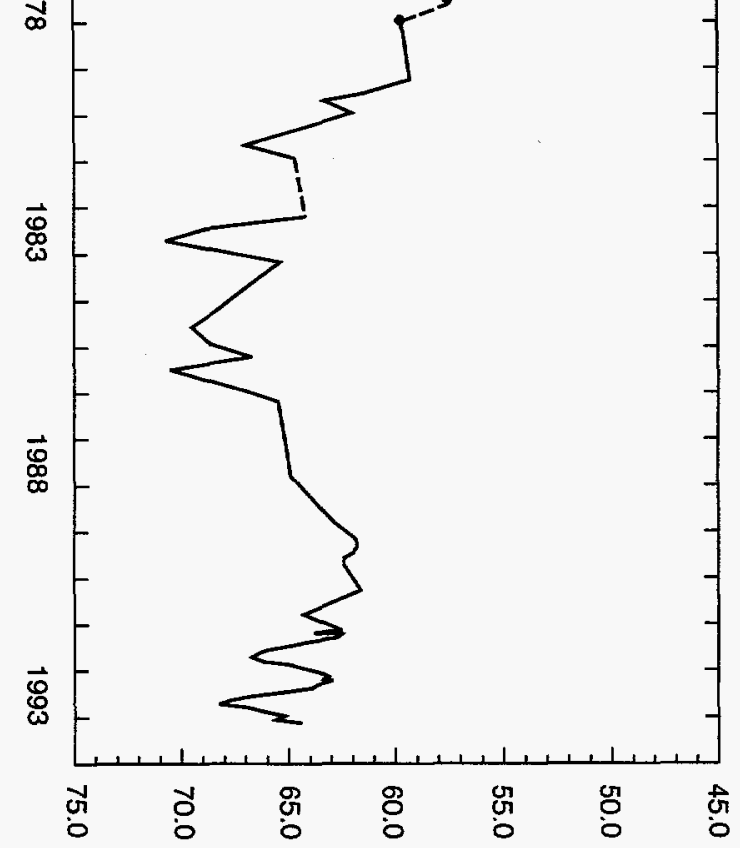

$\vec{\Phi}$

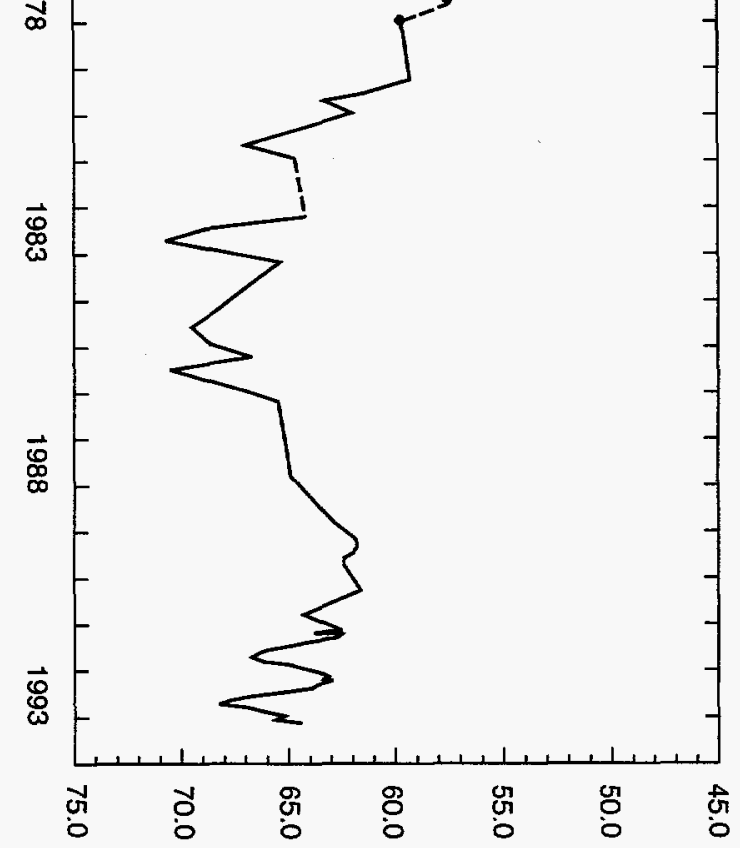

$\stackrel{0}{0}$

\&

WATER LEVEL, IN FEET BELOW LAND SURFACE 

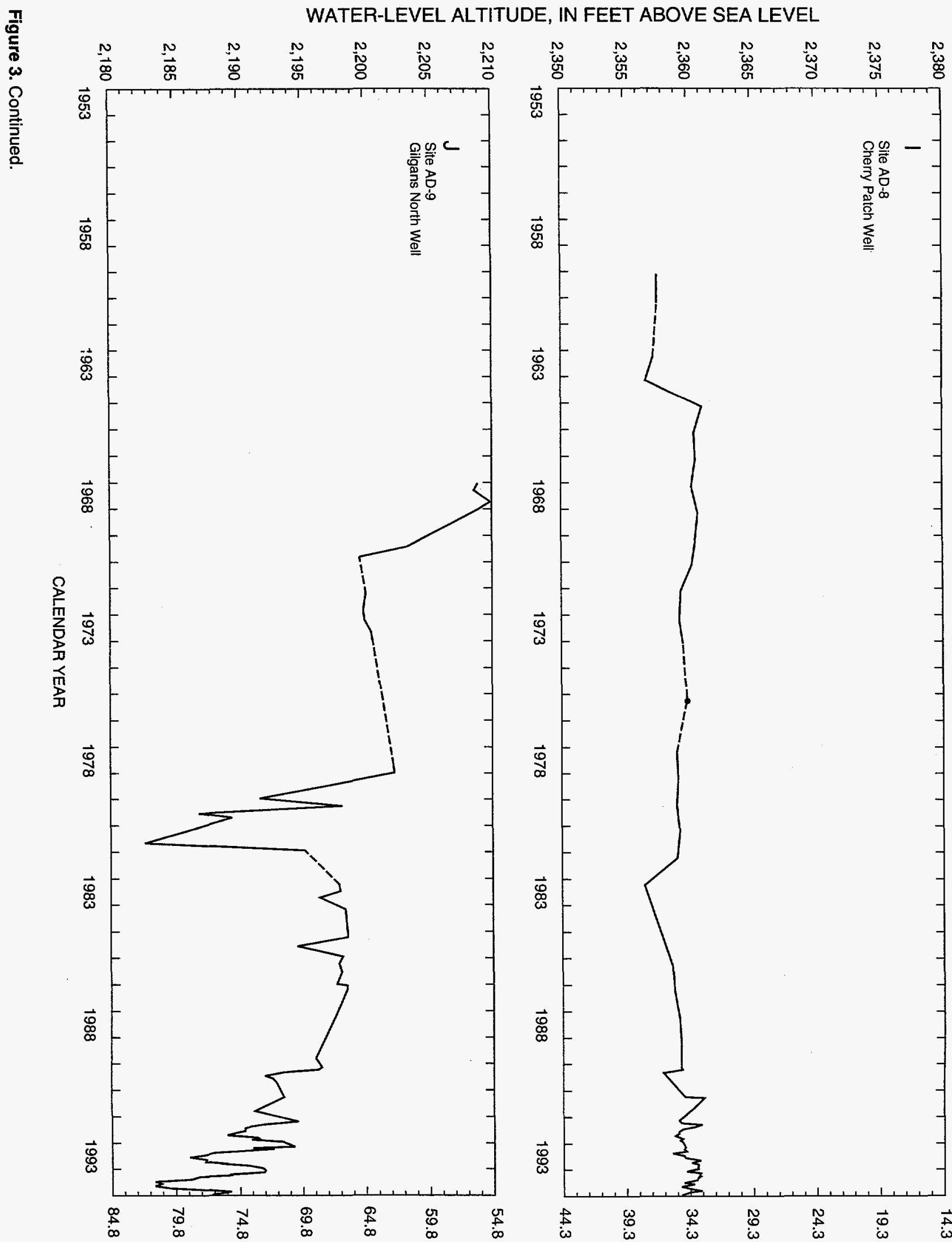

灾

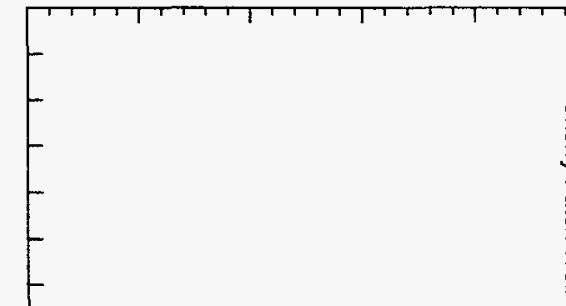

心

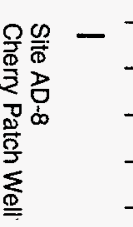

$\vec{Ð}$

$\vec{\leftrightarrow}$

$\vec{\Phi}$

-

-

怘

$\vec{Ð}$

离

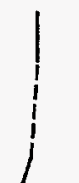

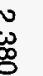




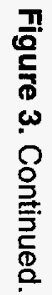

WATER-LEVEL ALTITUDE, IN FEET ABOVE SEA LEVEL

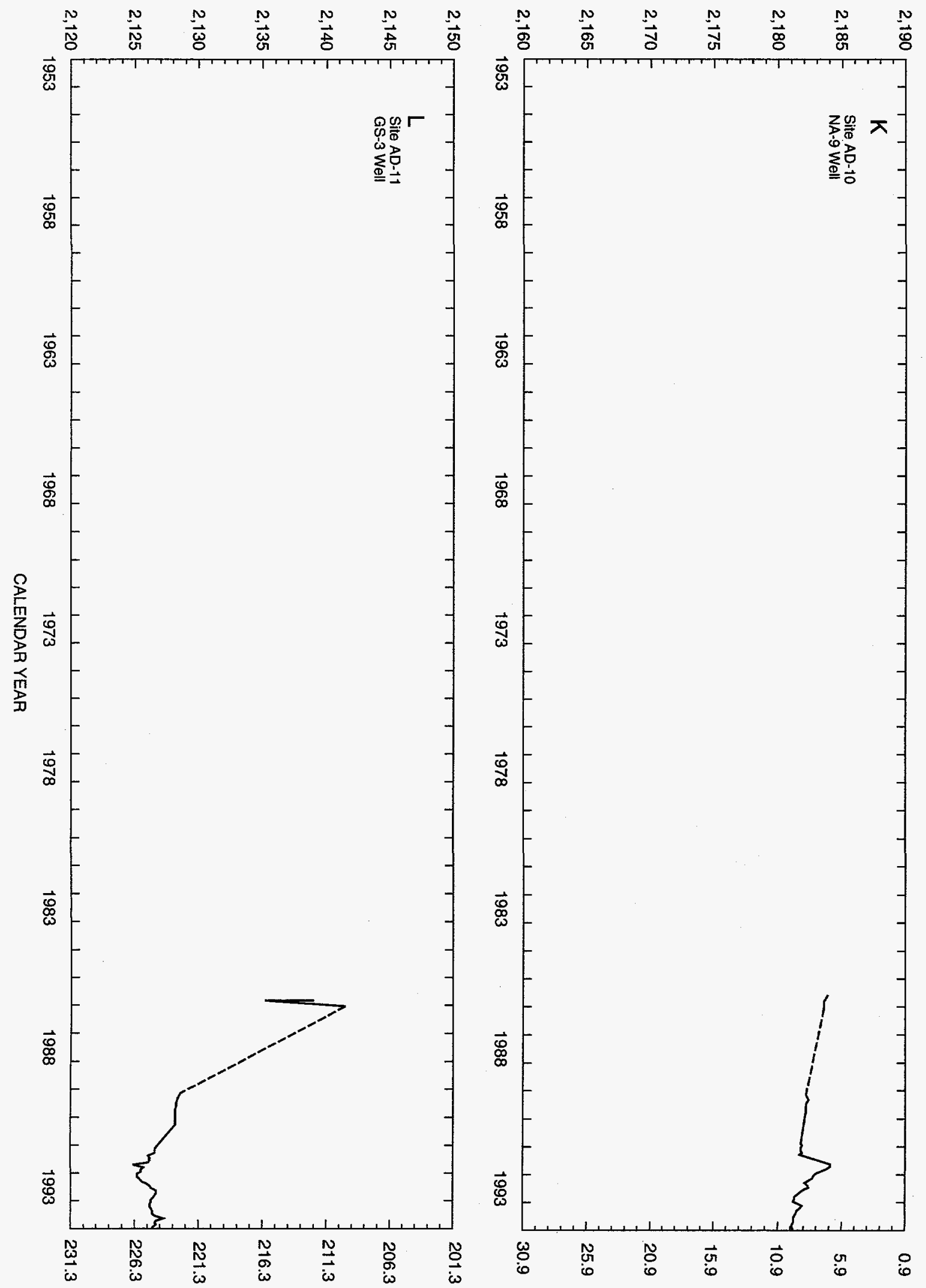

WATER LEVEL, IN FEET BELOW LAND SURFACE 


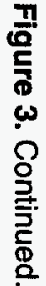

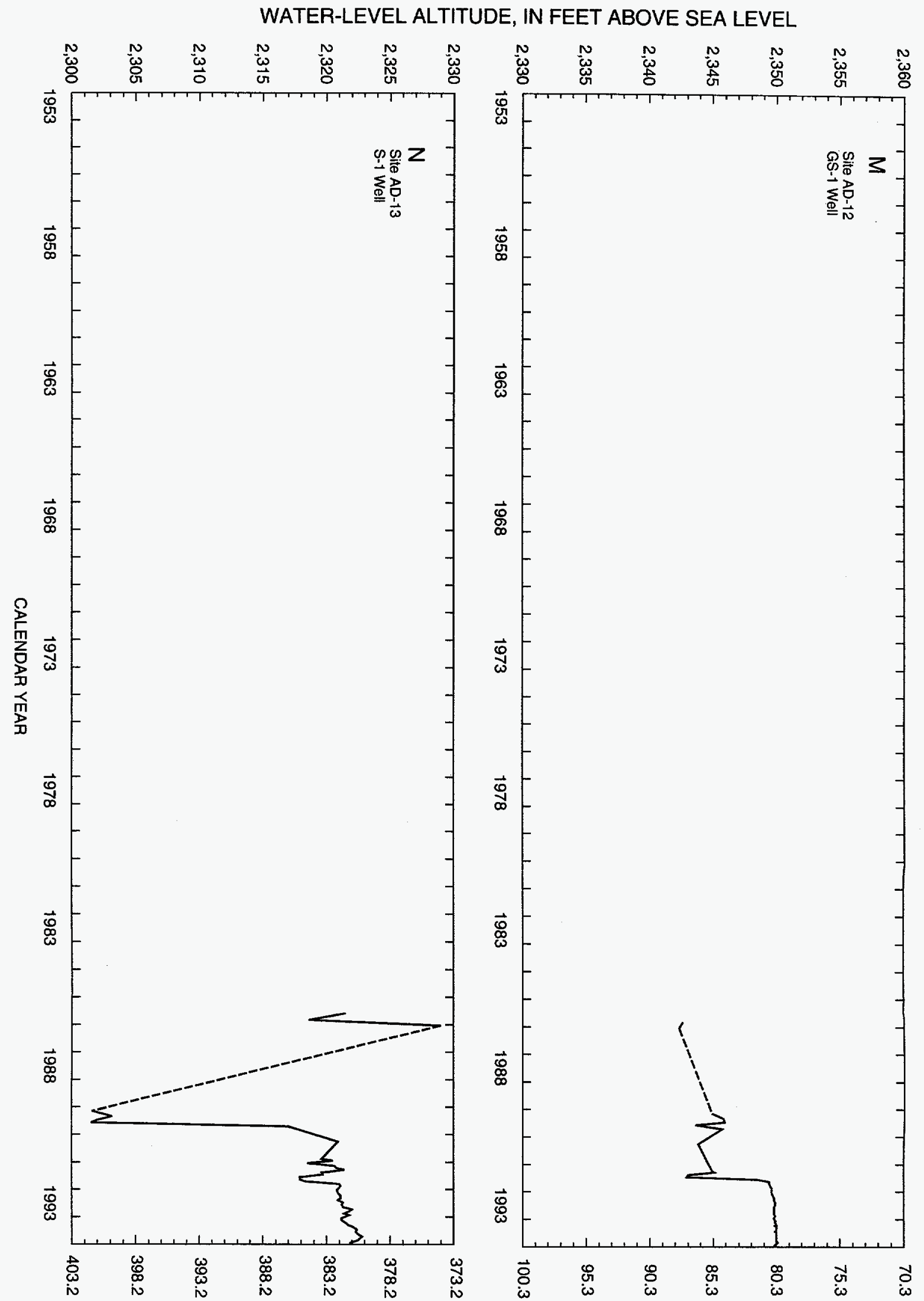

WATER LEVEL, IN FEET BELOW LAND SURFACE 


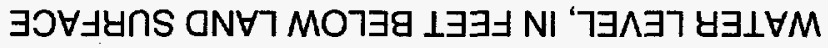

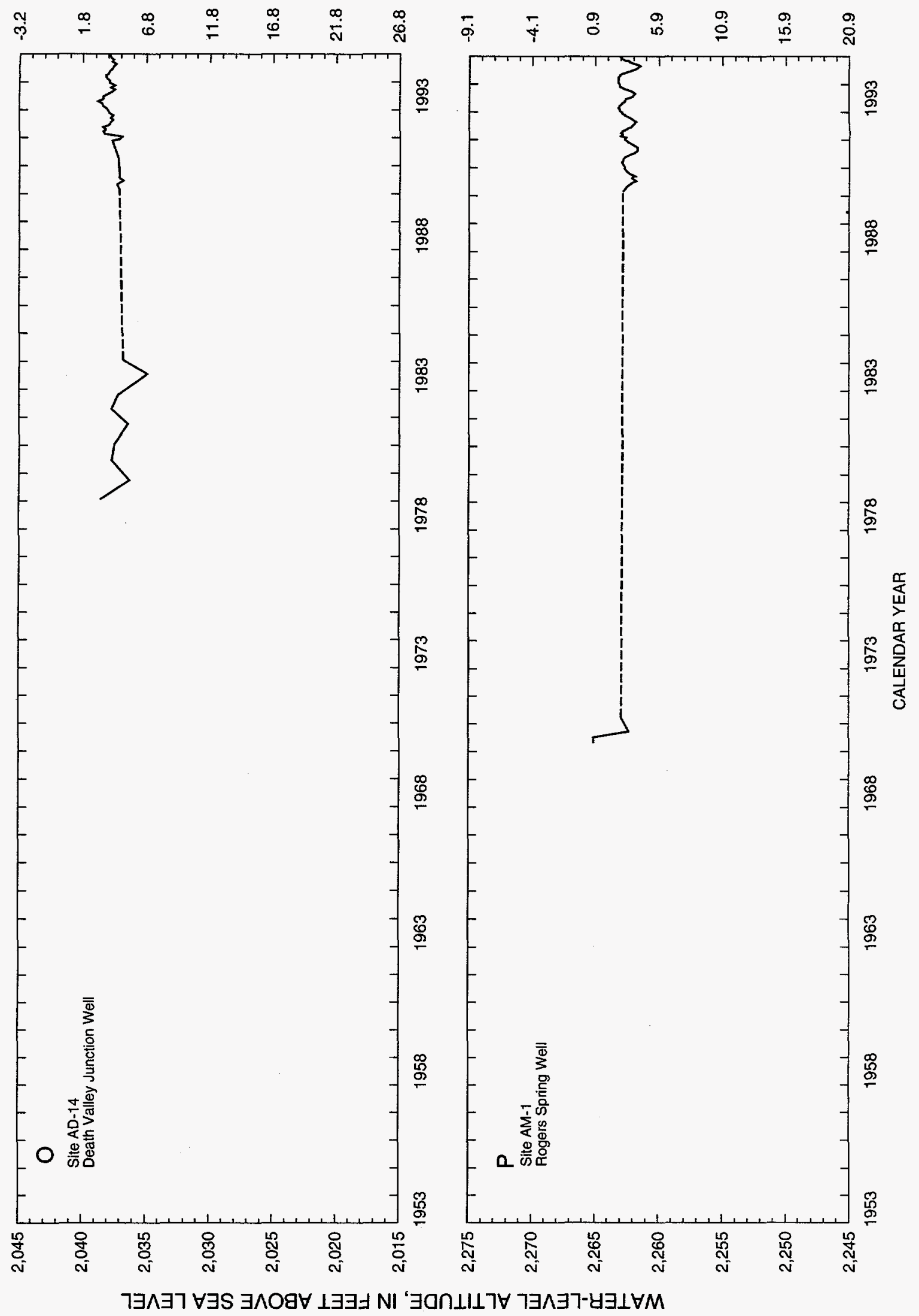

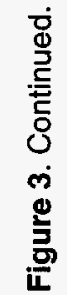



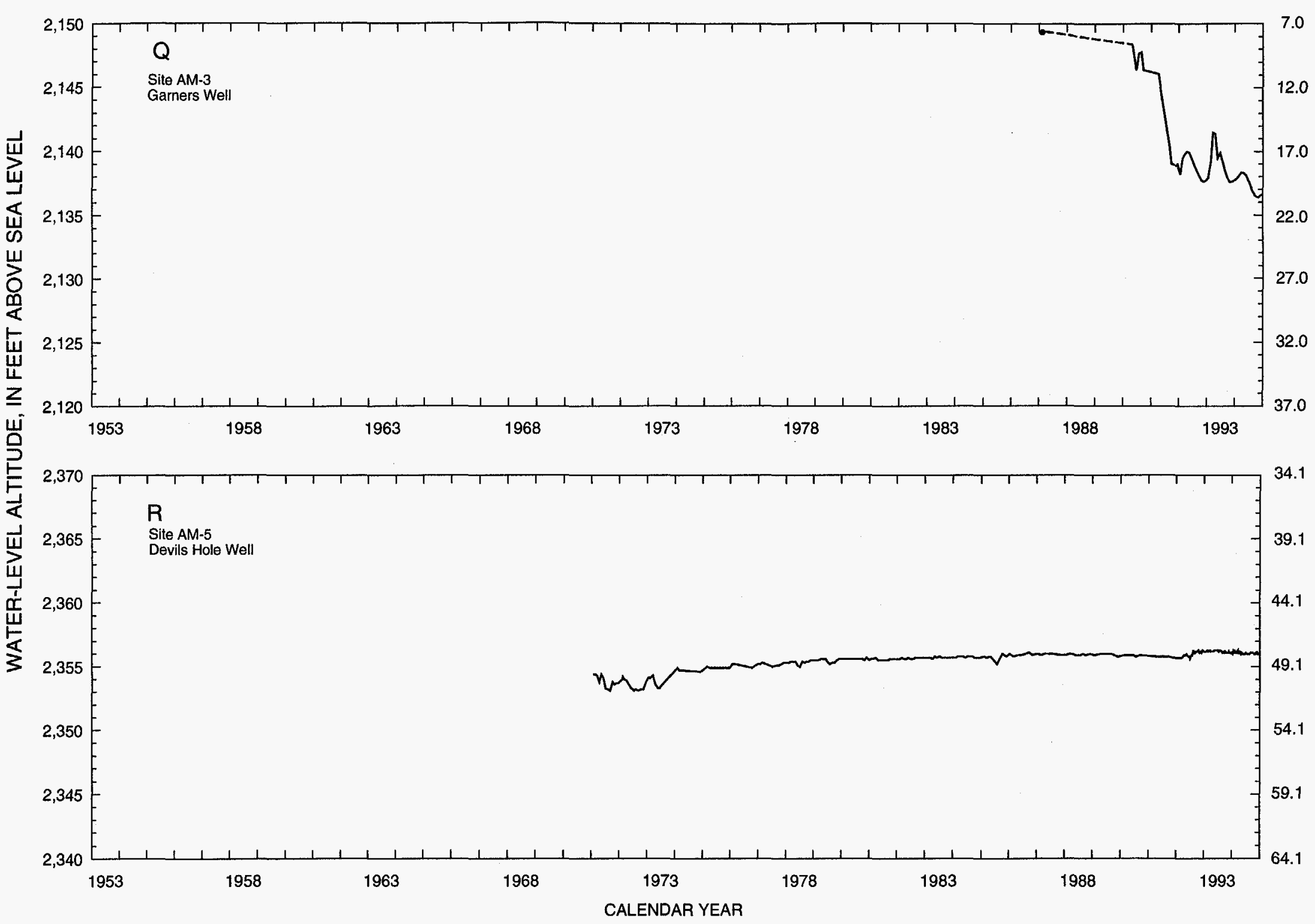

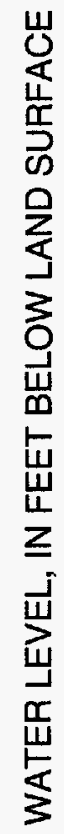

Figure 3. Continued 
$\exists \supset \forall\lrcorner$ UกS $\mathrm{N} \forall 7 \mathrm{MO} \exists \exists$

$\left.\perp \exists \exists \exists N{ }^{\prime}\right\urcorner \exists \wedge \exists 7$ y

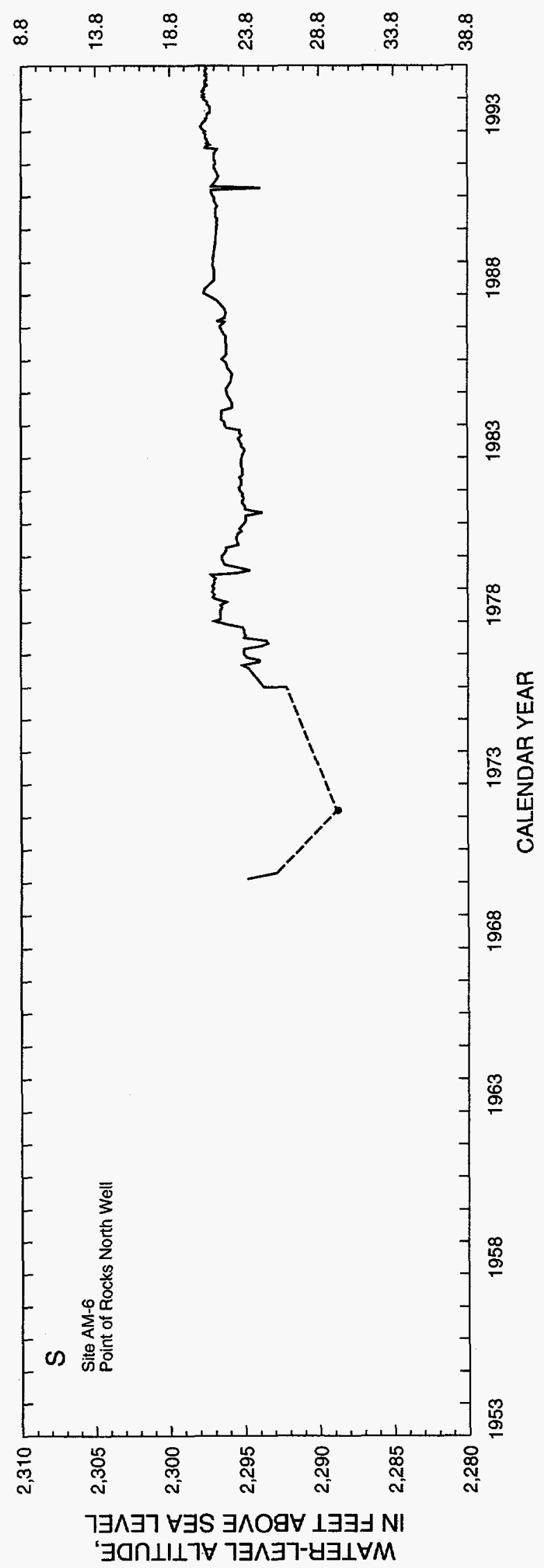

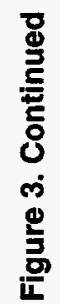




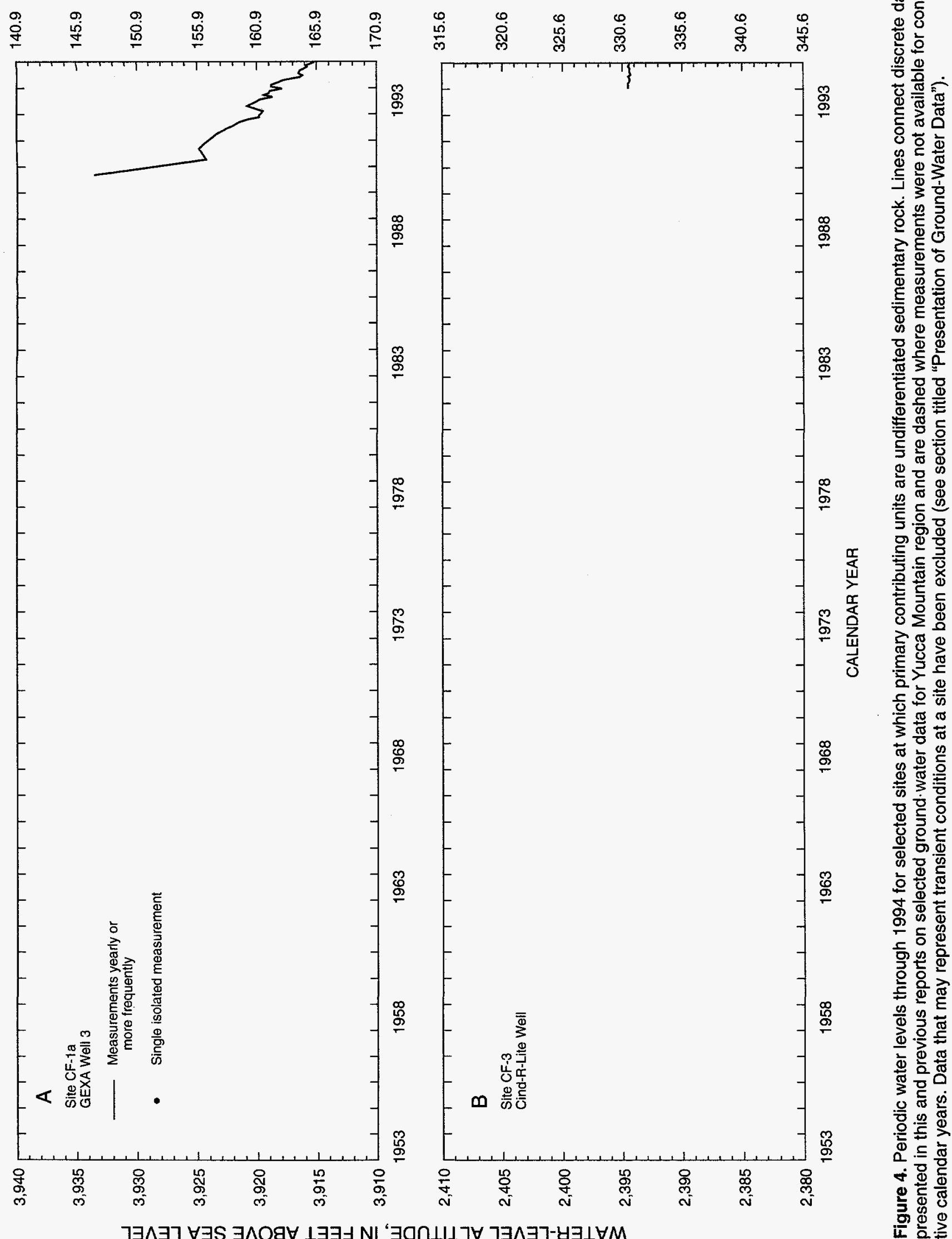




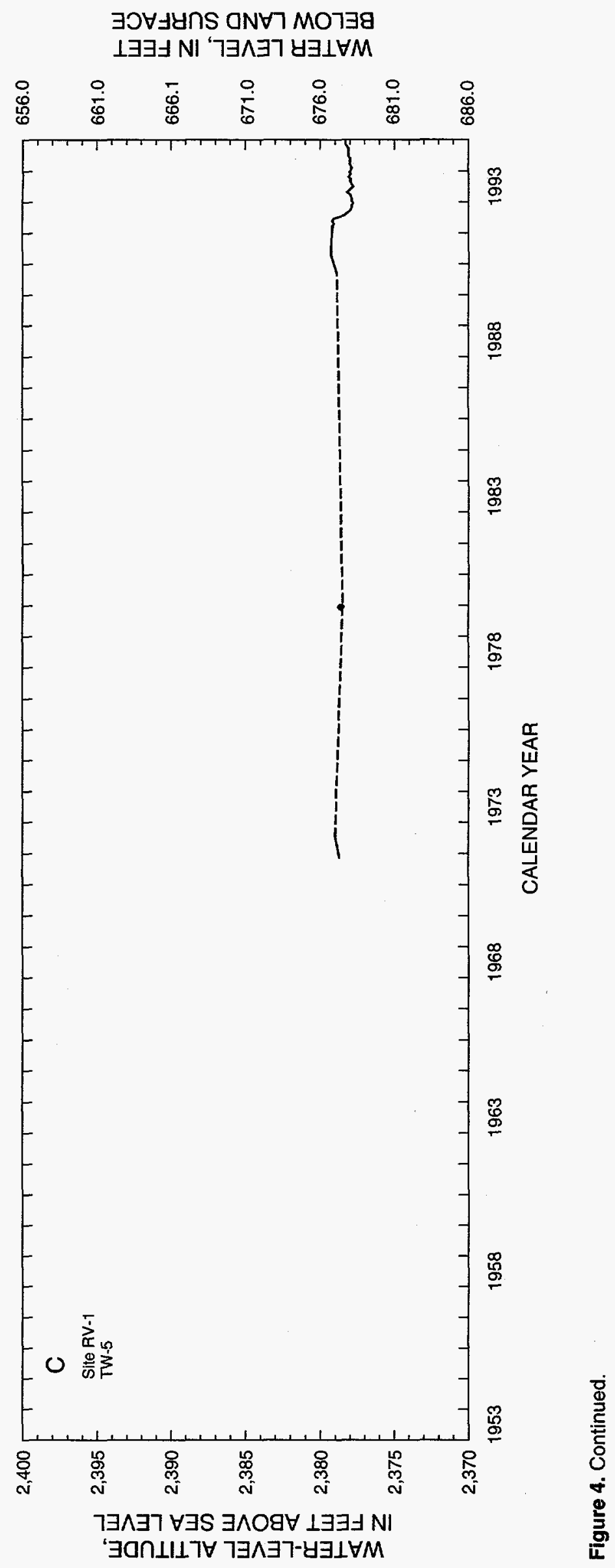




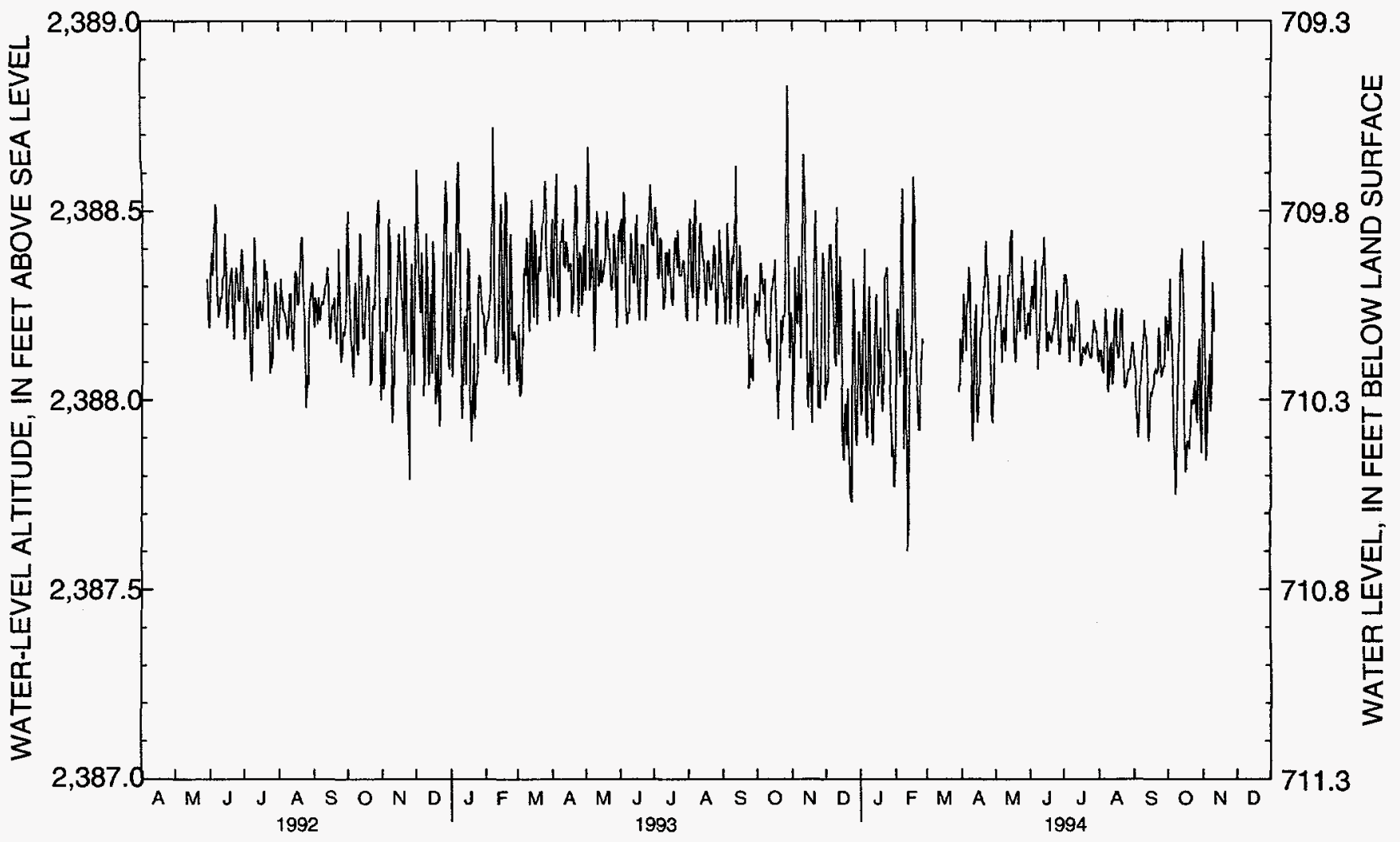

Figure 5. Daily average water levels in well JF-3, May 1992 through December 1994.

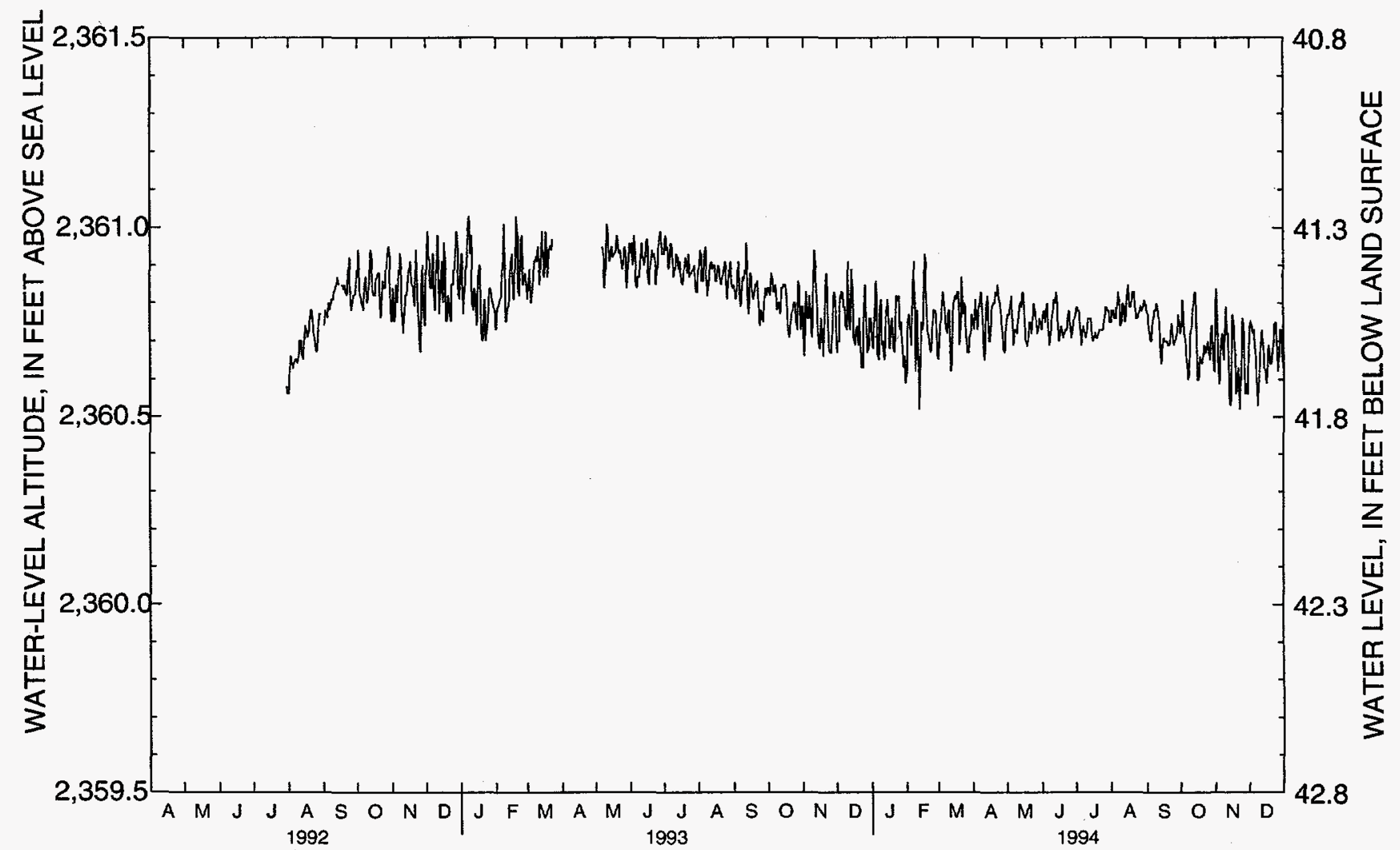

Figure 6. Daily average water levels in well AD-6, July 1992 through December 1994 


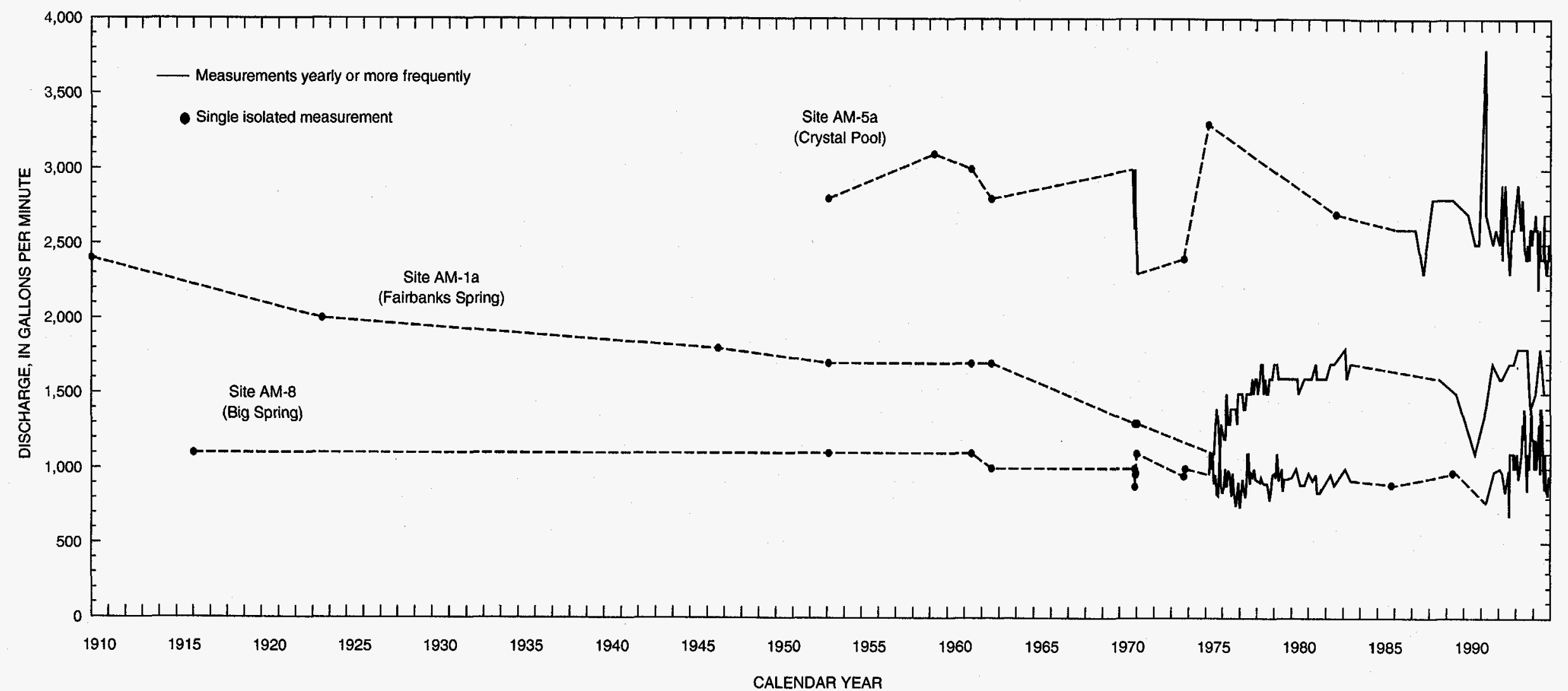

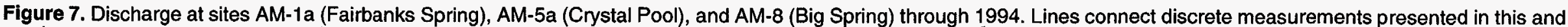
previous reports on selected ground-water data for Yucca Mountain region and are dashed where measurements were not available for consecutive calendar years. 


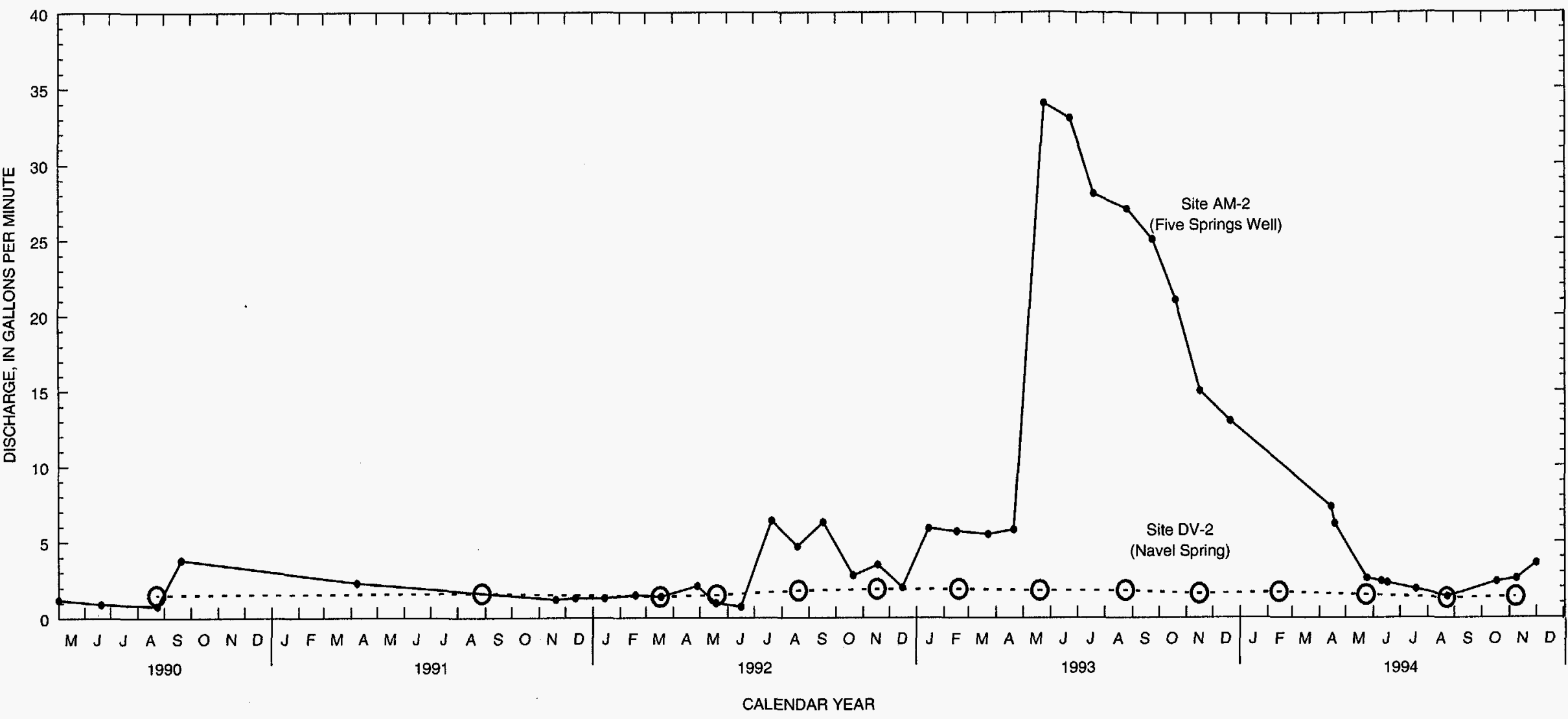

Figure 8. Discharge at sites AM-2 (Five Springs Well) and DV-2 (Navel Spring), 1990 through 1994. Symbols indicate discrete measurements presented in this and previous reports on selected ground-water data for Yucca Mountain region. 


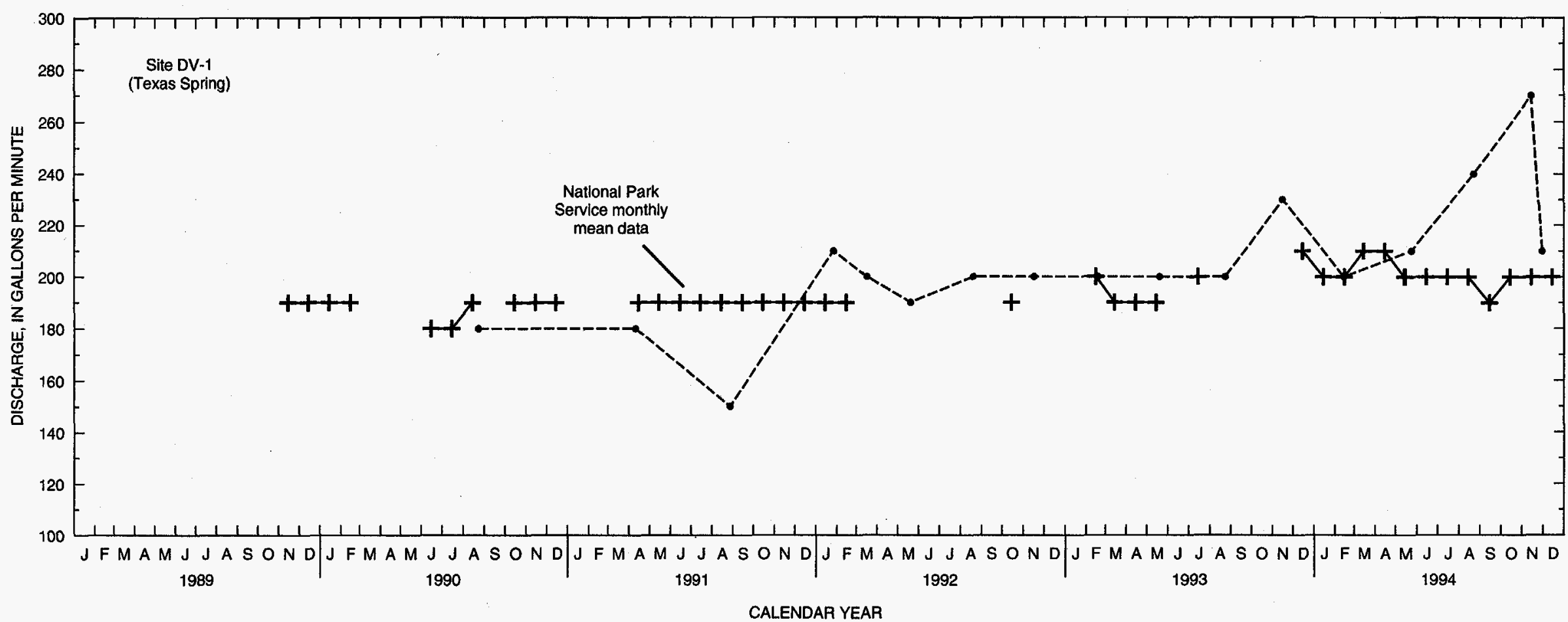

Figure 9. Discharge at site DV-1 (Texas Spring), 1989 through 1994. Dots indicate discrete USGS measurements presented in this and previous reports on selected ground-water data for Yucca Mountain region. Plus symbol represents the National Park Service monthly mean data for any given month. National Park Service monthly mean data are not connected by a line where data are not available for consecutive months. 


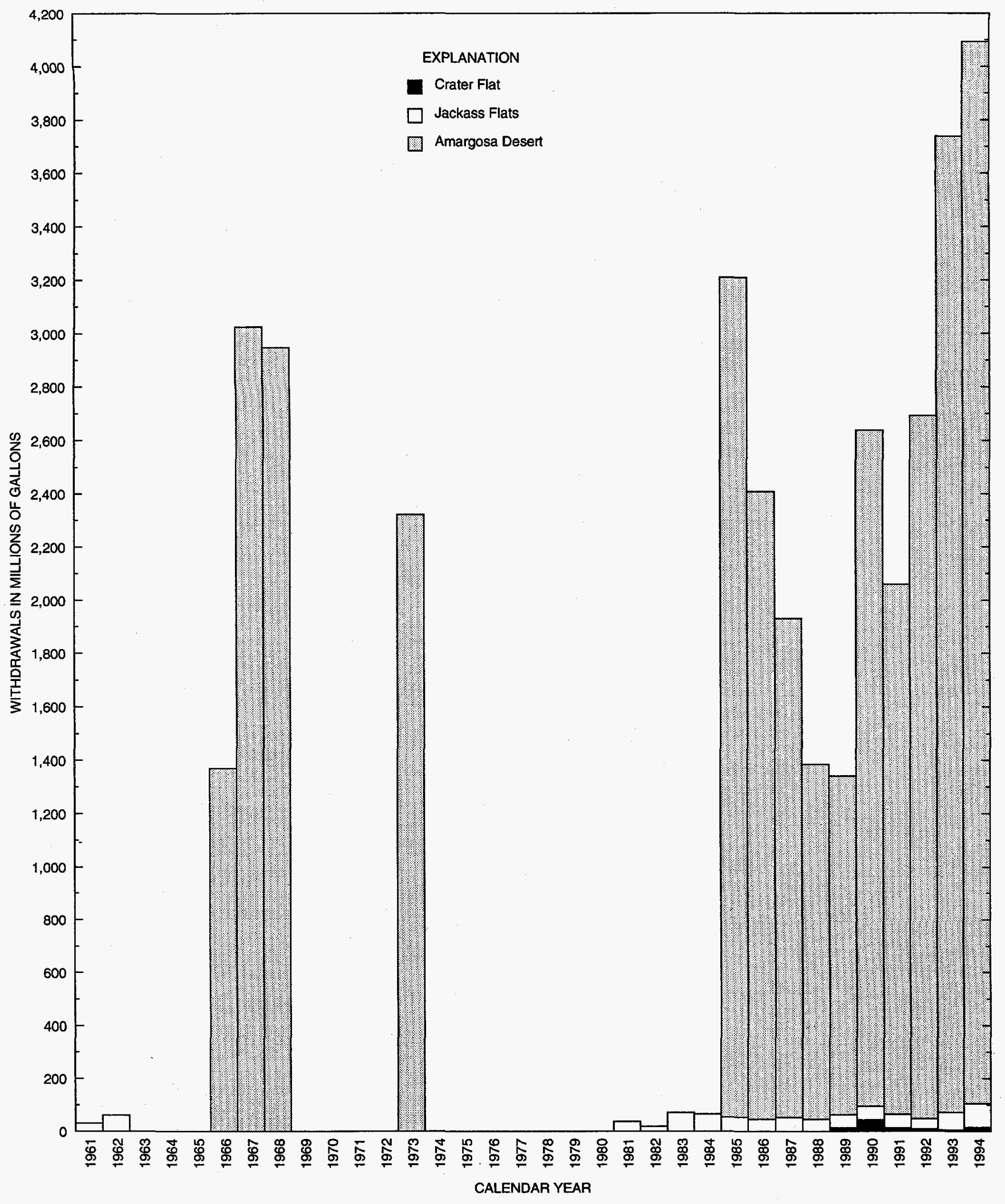

Figure 10. Available estimates of annual ground-water withdrawals for selected areas within Alkali Flat-Furnace Creek Ranch ground-water subbasin, 1961 through 1994. In each hydrographic area, ground water may have been withdrawn in years for which no estimates are available. Total bar height equals the approximate sum of withdrawals from all areas within subbasin for given year. 


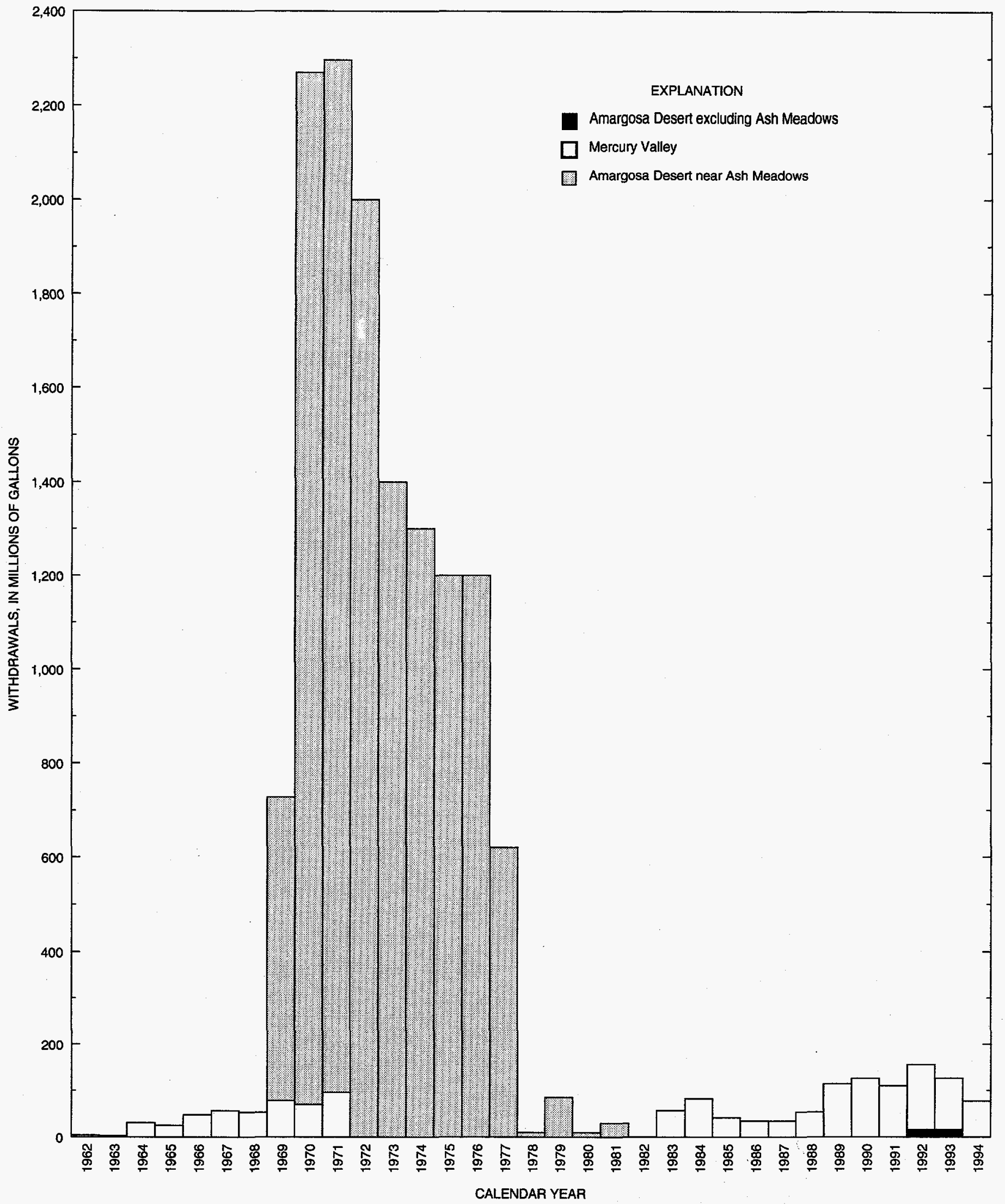

Figure 11. Available estimates of annual ground-water withdrawals for selected areas within Ash Meadows ground-water subbasin, 1962 through 1994. In each hydrographic area, ground water may have been withdrawn in years for which no estimates are available. Total bar height equals the approximate sum of withdrawals from all areas within subbasin for given year. 

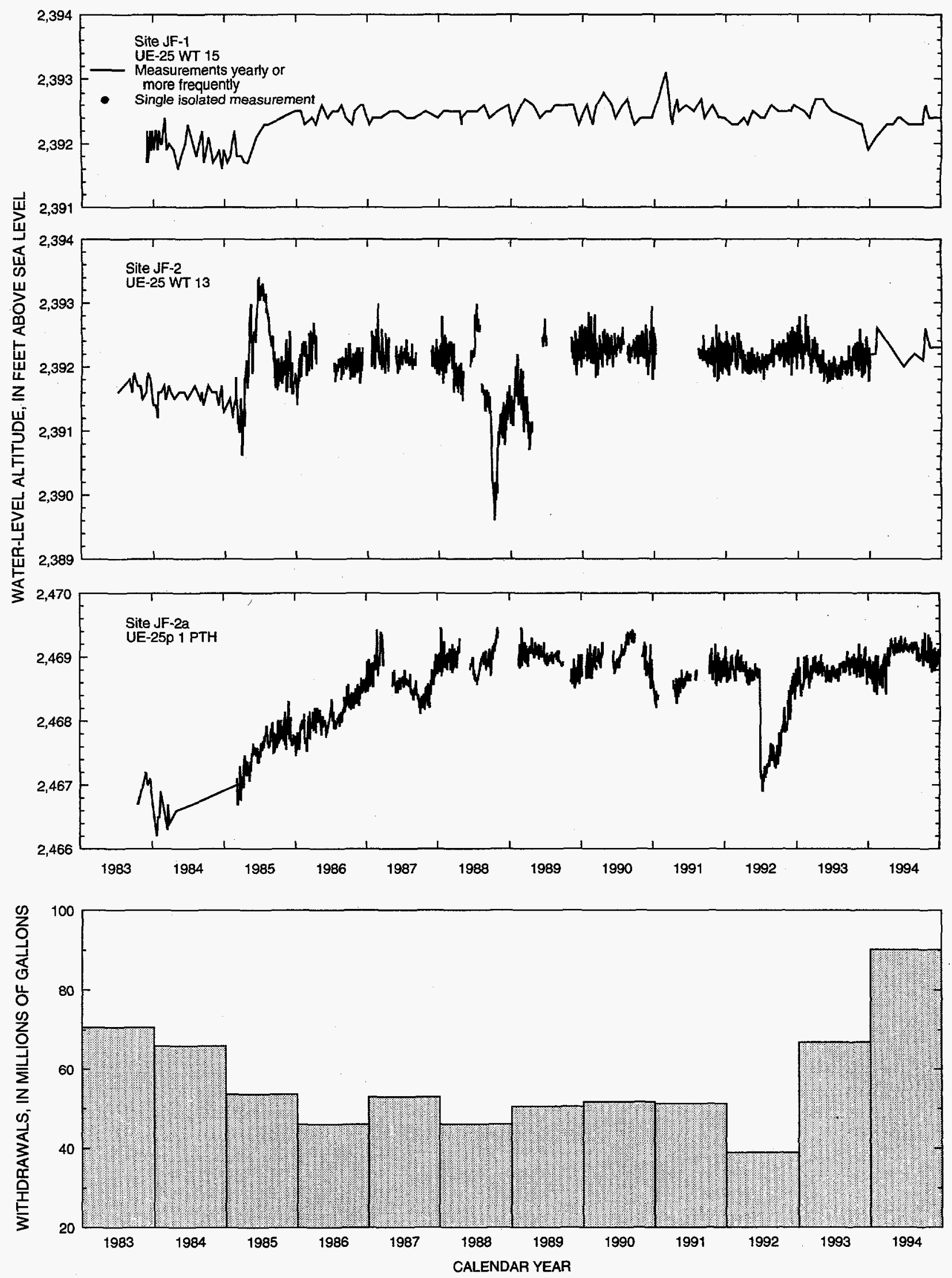

Figure 12. Water-level altitudes in wells JF-1, JF-2, JF-2a, J-13, J-11, J-12, and JF-3, and estimated ground-water withdrawals from Jackass Flats, 1983 through 1994. Lines connect discrete measurements or daily average water levels (when continual data recorded by instrumentation were available for more than half a year), and are dashed where measurements were not available for consecutive calendar years. Discrete measurements that may reflect transient conditions at a site have been excluded. Bar height for ground-water withdrawals equals sum of withdrawals from water-supply wells $\mathrm{J}-13$ and $\mathrm{J}-12$. 

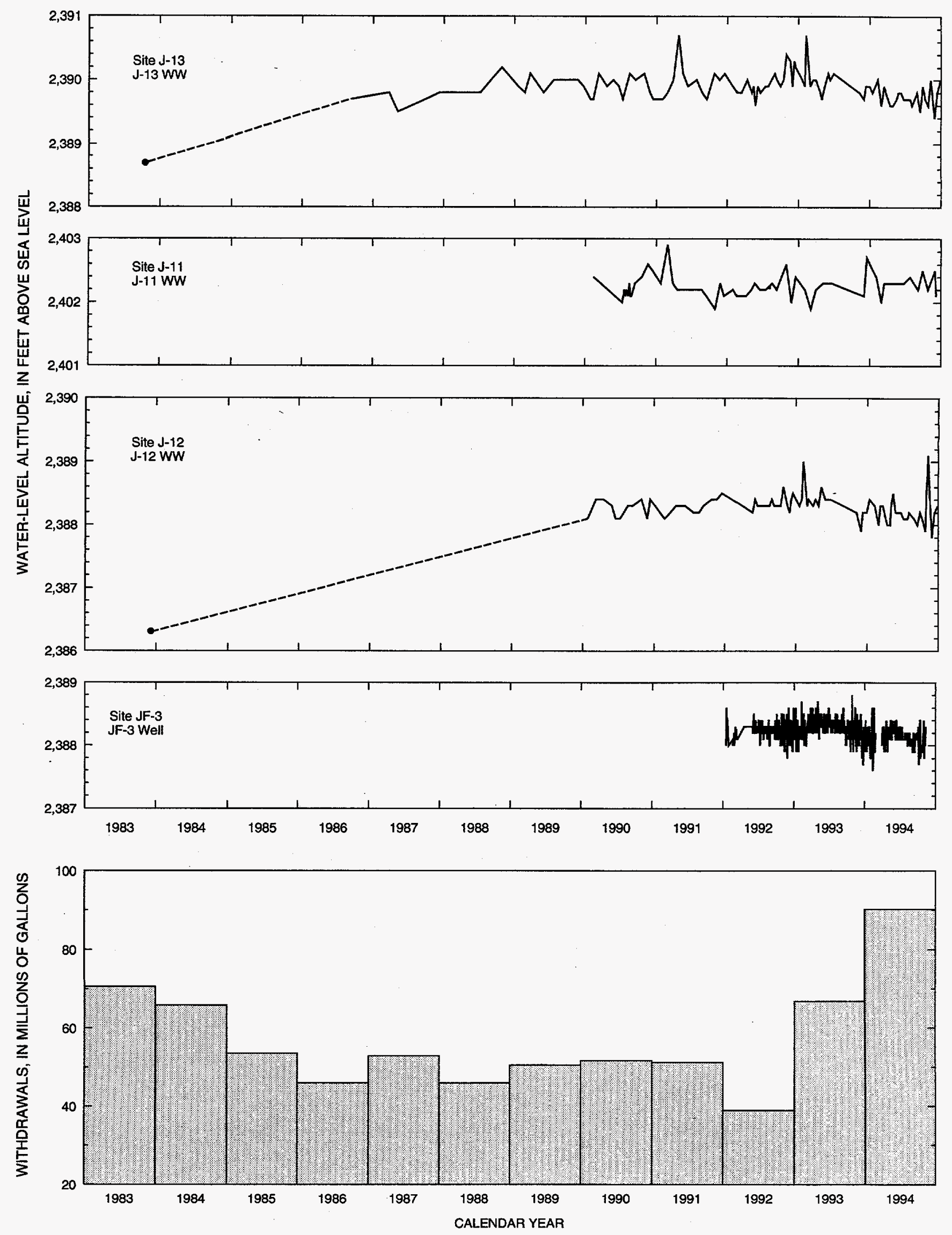

Figure 12. Continued. 

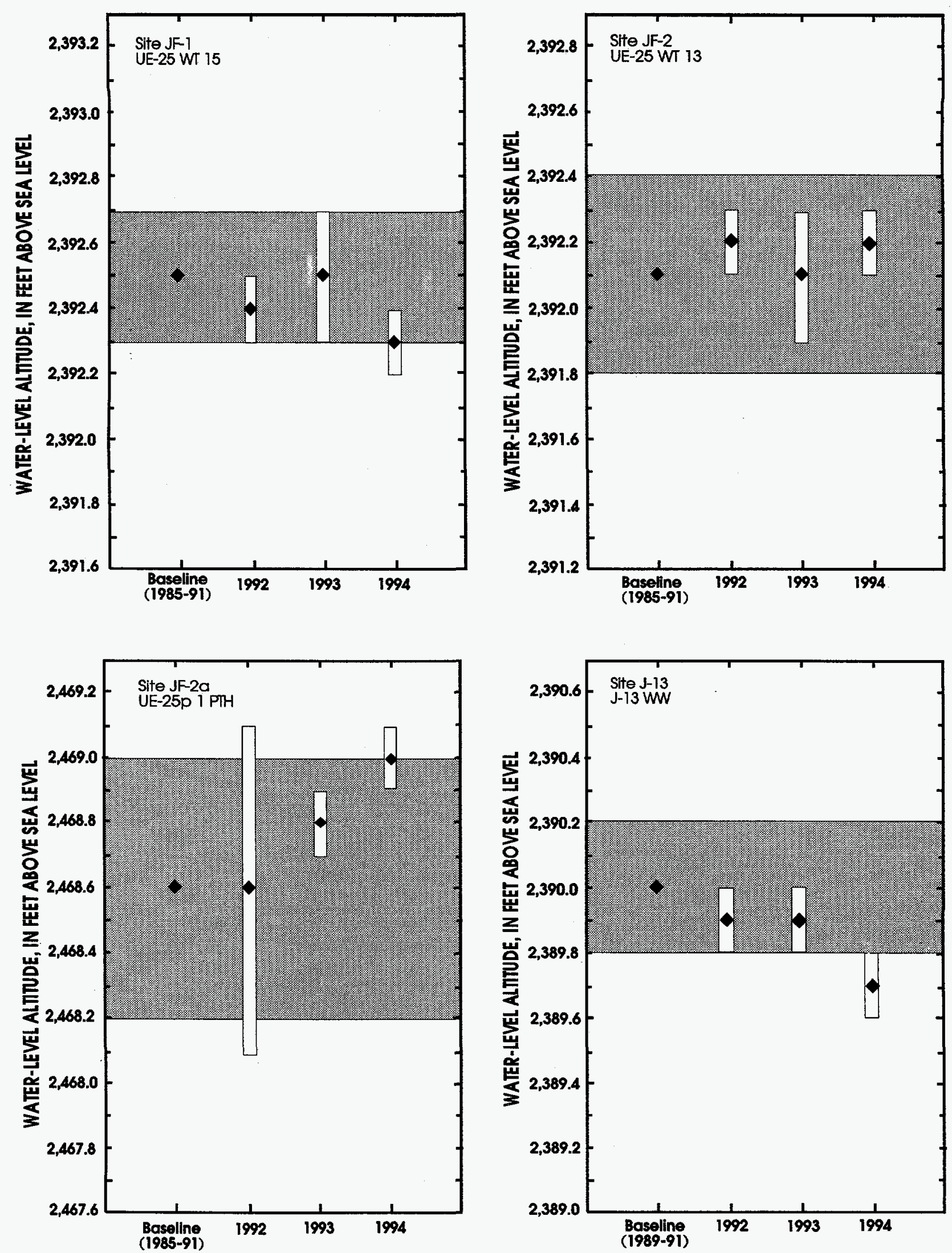

Figure 13. Median water-level altitudes and average deviation of water levels for wells JF-1, JF-2, JF-2a, J-13, J-11, J-12, and JF-3 for selected baseline periods and for calendar years 1992 through 1994. 

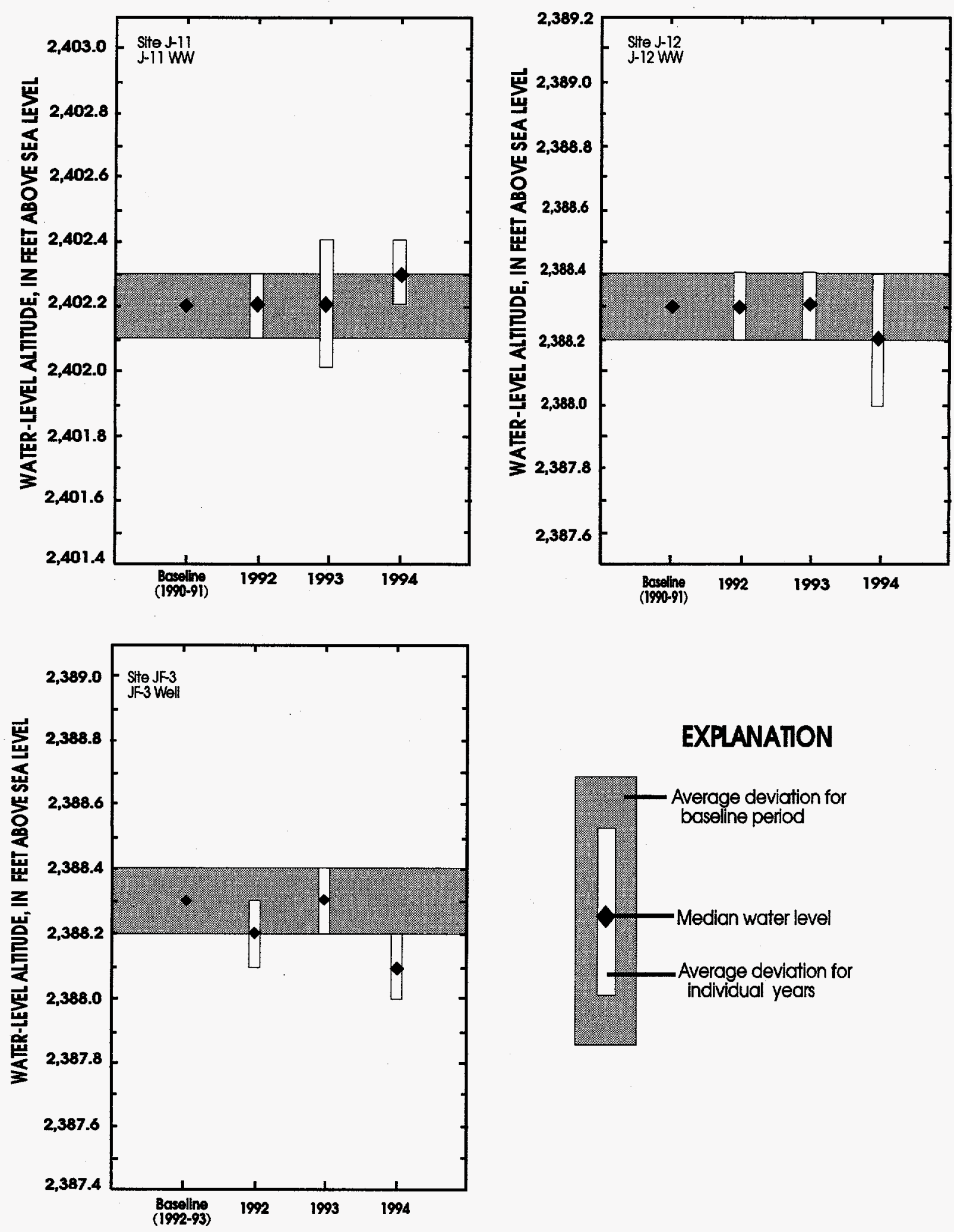

EXPLANATION

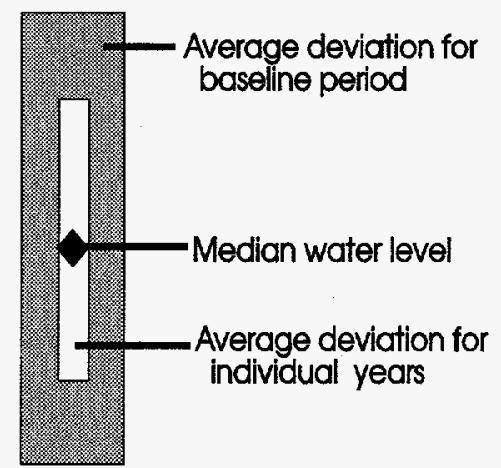

Figure 13. Continued. 
Table 5. Periodic measurements of water levels at monitoring sites in Yucca Mountain region for calendar year 1994 Site number: Sites are grouped by hydrographic area and, within each area, are listed in general north-to-south, then west-to-east order. See text section titled "Site Number" for further
discussion.

U.S. Geological Survey site identification; Unique identification number for site as stored in files and data bases of U.S. Geological Survey (USGS).

Land-surface altitude: Altitude of land surface in vicinity of site. Exception is altitude for site AM-4, which is altitude of bolt that serves as measurement point. Altitudes are reported to nearest 0.1 foot and were derived from USGS land surveys.

Height of measurement point: Height of measurement point (MP) most recently used. MP is stable, recoverable point from which periodic measurements to depth of water are made. MP at site AM- 4 is bolt fastened to south.wall of fissure, and is not referenced to land surface. Negative number indicates MP is below land surface.

Depth to water: Depths listed generally represent water level below land surface. Exceptions are site AM-4, where data represent water level below measurement point, and site AM-2, where negative numbers represent water levels above land surface. Site AM-2 is flowing well with water standing above land surface in casing. Apparent differences in depth to water at sites that list data from several sources may result from differing estimates of distance from land surface to measurement point used.

Method: Method used to measure depth to water. A, average monthly water level, reported for 15th of month; B, depth to water calculated from millivolt output of transducer installed in well and most recent calibration of instrumentation; $\mathrm{N}$, depth to water is measured below measurement point with ruled tape; $\mathrm{S}$, steel tape; $\mathrm{T}$, uncalibrated electric tape; $\mathrm{V}$, calibrated electric tape; $Z$, measurement method unknown.

Sitestatus: Known conditions at site that may have affected measured depth to water. F, flowing; P, pumping; R, well recently pumped; S, nearby well pumping during measurement..

Data source: EMP, Environmental-Monitoring Program (USGS); NDWR, Nevada Division of Water Resources; NPS, National Park Service; NTS, Hydrologic Resources Management and Environmental Restoration Programs (USGS); PVT, private owner measurement; SCP, Site-Characterization Project (USGS); USFWS, U.S. Fish and Wildlife Service; USGS-NV, other Nevada District Programs.

\begin{tabular}{|c|c|c|c|c|c|c|c|c|c|c|c|}
\hline \multirow[b]{2}{*}{$\begin{array}{c}\text { Site } \\
\text { number } \\
\text { (plate 1) }\end{array}$} & \multirow[b]{2}{*}{$\begin{array}{l}\text { U.S. Geological } \\
\text { Survey site } \\
\text { identification }\end{array}$} & \multirow[b]{2}{*}{ Site name } & \multirow[b]{2}{*}{$\begin{array}{l}\text { Land- } \\
\text { surface } \\
\text { altitude } \\
\text { (feet } \\
\text { above } \\
\text { sea } \\
\text { level) }\end{array}$} & \multirow{2}{*}{$\begin{array}{l}\text { Height of } \\
\text { measure- } \\
\text { ment } \\
\text { point } \\
\text { (feet } \\
\text { above } \\
\text { land } \\
\text { surface) }\end{array}$} & \multicolumn{7}{|c|}{ Water-level measurement } \\
\hline & & & & & Date & Time & $\begin{array}{l}\text { Depth } \\
\text { to water } \\
\text { (feet } \\
\text { below } \\
\text { land } \\
\text { surface) }\end{array}$ & $\begin{array}{c}\text { Altitude } \\
\text { of water } \\
\text { surface } \\
\text { (feet } \\
\text { above } \\
\text { sea level) }\end{array}$ & Method & $\begin{array}{c}\text { Site } \\
\text { status }\end{array}$ & $\begin{array}{l}\text { Data } \\
\text { source }\end{array}$ \\
\hline \multirow[t]{3}{*}{ CF- 1} & 365520116370301 & GEXA Well 4 & $3,930.9$ & 1.82 & $\begin{array}{l}01-20-1994 \\
02-17-1994 \\
03-23-1994 \\
04-20-1994 \\
05-27-1994\end{array}$ & $\begin{array}{l}0910 \\
1050 \\
1440 \\
1025 \\
1035\end{array}$ & $\begin{array}{l}617.88 \\
617.33 \\
617.38 \\
617.56 \\
617.48\end{array}$ & $\begin{array}{l}3,313.0 \\
3,313.6 \\
3,313.5 \\
3,313.3 \\
3,313.4\end{array}$ & $\begin{array}{l}\text { V } \\
\text { V } \\
\text { V } \\
\text { V } \\
\text { V }\end{array}$ & $\begin{array}{l}- \\
- \\
- \\
-\end{array}$ & $\begin{array}{l}\text { EMP } \\
\text { EMP } \\
\text { EMP } \\
\text { EMP } \\
\text { EMP }\end{array}$ \\
\hline & & & & & $\begin{array}{l}06-22-1994 \\
07-20-1994 \\
08-29-1994 \\
09-21-1994 \\
10-20-1994\end{array}$ & $\begin{array}{l}1245 \\
1225 \\
1325 \\
1200 \\
0840\end{array}$ & $\begin{array}{r}617.62 \\
617.60 \\
617.45 \\
617.46 \\
617.40\end{array}$ & $\begin{array}{l}3,313.3 \\
3,313.3 \\
3,313.4 \\
3,313.4 \\
3,313.5\end{array}$ & $\begin{array}{l}\mathrm{V} \\
\mathrm{V} \\
\mathrm{V} \\
\mathrm{V} \\
\mathrm{V}\end{array}$ & $\begin{array}{l}- \\
- \\
- \\
-\end{array}$ & $\begin{array}{l}\text { EMP } \\
\text { EMP } \\
\text { EMP } \\
\text { EMP } \\
\text { EMP }\end{array}$ \\
\hline & & & & & $\begin{array}{l}11-10-1994 \\
12-22-1994\end{array}$ & $\begin{array}{l}1100 \\
1200\end{array}$ & $\begin{array}{l}617.12 \\
617.41\end{array}$ & $\begin{array}{l}3,313.8 \\
3,313.5\end{array}$ & $\begin{array}{l}\mathrm{V} \\
\mathrm{V}\end{array}$ & - & $\begin{array}{l}\text { EMP } \\
\text { EMP }\end{array}$ \\
\hline
\end{tabular}


Table 5. Periodic measurements of water levels at monitoring sites in Yucca Mountain region for calendar year 1994-Continued

\begin{tabular}{|c|c|c|c|c|c|c|c|c|c|c|c|}
\hline \multirow[b]{2}{*}{$\begin{array}{c}\text { Site } \\
\text { number } \\
\text { (plate 1) }\end{array}$} & \multirow[b]{2}{*}{$\begin{array}{l}\text { U.S. Geological } \\
\text { Survey site } \\
\text { identification }\end{array}$} & \multirow[b]{2}{*}{ Site name } & \multirow[b]{2}{*}{$\begin{array}{l}\text { Land- } \\
\text { surface } \\
\text { altitude } \\
\text { (feet } \\
\text { above } \\
\text { sea } \\
\text { level) }\end{array}$} & \multirow{2}{*}{$\begin{array}{l}\text { Height of } \\
\text { measure- } \\
\text { ment } \\
\text { point } \\
\text { (feet } \\
\text { above } \\
\text { land } \\
\text { surface) }\end{array}$} & \multicolumn{7}{|c|}{ Water-level measurement } \\
\hline & & & & & Date & Time & $\begin{array}{l}\text { Depth } \\
\text { to water } \\
\text { (feet } \\
\text { below } \\
\text { land } \\
\text { surface) }\end{array}$ & $\begin{array}{c}\text { Altitude } \\
\text { of water } \\
\text { surface } \\
\text { (feet } \\
\text { above } \\
\text { sea level) }\end{array}$ & Method & $\begin{array}{l}\text { Site } \\
\text { status }\end{array}$ & $\begin{array}{l}\text { Data } \\
\text { source }\end{array}$ \\
\hline \multirow[t]{3}{*}{ CF- 1a } & 365445116383901 & GEXA Well 3 & $4,080.9$ & 1.68 & $\begin{array}{l}01-20-1994 \\
02-17-1994 \\
03-23-1994 \\
04-20-1994 \\
05-31-1994\end{array}$ & $\begin{array}{l}0845 \\
1014 \\
1415 \\
1005 \\
1445\end{array}$ & $\begin{array}{l}162.08 \\
162.11 \\
162.68 \\
163.14 \\
164.51\end{array}$ & $\begin{array}{l}3,918.8 \\
3,918.8 \\
3,918.2 \\
3,917.8 \\
3,916.4\end{array}$ & $\begin{array}{l} \\
S \\
S \\
S \\
S\end{array}$ & $\begin{array}{l}- \\
- \\
- \\
-\end{array}$ & $\begin{array}{l}\text { EMP } \\
\text { EMP } \\
\text { EMP } \\
\text { EMP } \\
\text { EMP }\end{array}$ \\
\hline & & & & & $\begin{array}{l}06-22-1994 \\
07-20-1994 \\
08-29-1994 \\
09-21-1994 \\
10-20-1994\end{array}$ & $\begin{array}{l}1224 \\
1200 \\
1240 \\
1115 \\
0815\end{array}$ & $\begin{array}{l}164.66 \\
164.44 \\
164.54 \\
164.84 \\
165.07\end{array}$ & $\begin{array}{l}3,916.2 \\
3,916.5 \\
3,916.4 \\
3,916.1 \\
3,915.8\end{array}$ & $\begin{array}{l}\mathbf{S} \\
\mathrm{S} \\
\mathrm{S} \\
\mathrm{S} \\
\mathrm{S}\end{array}$ & $\begin{array}{l}- \\
- \\
-\end{array}$ & $\begin{array}{l}\text { EMP } \\
\text { EMP } \\
\text { EMP } \\
\text { EMP } \\
\text { EMP }\end{array}$ \\
\hline & & & & & $\begin{array}{l}11-10-1994 \\
12-22-1994\end{array}$ & $\begin{array}{l}1035 \\
1145\end{array}$ & $\begin{array}{l}164.99 \\
165.67\end{array}$ & $\begin{array}{l}3,915.9 \\
3,915.2\end{array}$ & $\begin{array}{l}S \\
S\end{array}$ & - & $\begin{array}{l}\text { EMP } \\
\text { EMP }\end{array}$ \\
\hline \multirow[t]{3}{*}{ CF- 2} & 364732116330701 & USW VH-1 & $3,161.1$ & 1.17 & $\begin{array}{l}02-01-1994 \\
02-25-1994 \\
03-29-1994 \\
04-22-1994 \\
05-05-1994\end{array}$ & $\begin{array}{l}1110 \\
1158 \\
1238 \\
1123 \\
1144\end{array}$ & $\begin{array}{l}603.92 \\
603.78 \\
603.81 \\
603.80 \\
603.70\end{array}$ & $\begin{array}{l}2,557.2 \\
2,557.3 \\
2,557.3 \\
2,557.3 \\
2,557.4\end{array}$ & $\begin{array}{l}S \\
S \\
S \\
S \\
S\end{array}$ & $\begin{array}{l}- \\
- \\
- \\
-\end{array}$ & $\begin{array}{l}\text { SCP } \\
\text { SCP } \\
\text { SCP } \\
\text { SCP } \\
\text { SCP }\end{array}$ \\
\hline & & & & & $\begin{array}{l}06-08-1994 \\
07-29-1994 \\
08-25-1994 \\
09-22-1994 \\
10-26-1994\end{array}$ & $\begin{array}{l}1002 \\
1146 \\
1253 \\
1343 \\
1335\end{array}$ & $\begin{array}{l}603.94 \\
603.80 \\
603.80 \\
603.77 \\
603.75\end{array}$ & $\begin{array}{l}2,557.2 \\
2,557.3 \\
2,557.3 \\
2,557.3 \\
2,557.4\end{array}$ & $\begin{array}{l}S \\
S \\
S \\
S \\
S\end{array}$ & $\begin{array}{l}- \\
- \\
-\end{array}$ & $\begin{array}{l}\text { SCP } \\
\text { SCP } \\
\text { SCP } \\
\text { SCP } \\
\text { SCP }\end{array}$ \\
\hline & & & & & $\begin{array}{l}11-22-1994 \\
12-09-1994 \\
12-09-1994\end{array}$ & $\begin{array}{l}1153 \\
0936 \\
1001\end{array}$ & $\begin{array}{l}603.99 \\
603.87 \\
603.87\end{array}$ & $\begin{array}{l}2,557.1 \\
2,557.2 \\
2,557.2\end{array}$ & $\begin{array}{l}S \\
S \\
S\end{array}$ & 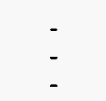 & $\begin{array}{l}\text { SCP } \\
\text { SCP } \\
\text { SCP }\end{array}$ \\
\hline \multirow[t]{3}{*}{$\mathrm{CF}-3$} & 364105116302601 & Cind-R-Lite Well & $2,725.6$ & -3.20 & $\begin{array}{l}01-14-1994 \\
02-03-1994 \\
03-23-1994 \\
04-20-1994 \\
05-27-1994\end{array}$ & $\begin{array}{l}0951 \\
0830 \\
1310 \\
0910 \\
0850\end{array}$ & $\begin{array}{l}331.13 \\
331.12 \\
331.13 \\
331.20 \\
331.22\end{array}$ & $\begin{array}{l}2,394.5 \\
2,394.5 \\
2,394.5 \\
2,394.4 \\
2,394.4\end{array}$ & $\begin{array}{l}\mathrm{V} \\
\mathrm{S} \\
\mathrm{S} \\
\mathrm{S} \\
\mathrm{S}\end{array}$ & $\begin{array}{l}- \\
- \\
- \\
-\end{array}$ & $\begin{array}{l}\text { EMP } \\
\text { EMP } \\
\text { EMP } \\
\text { EMP } \\
\text { EMP }\end{array}$ \\
\hline & & & & & $\begin{array}{l}06-22-1994 \\
07-20-1994 \\
08-29-1994 \\
09-21-1994 \\
10-19-1994\end{array}$ & $\begin{array}{l}1110 \\
1040 \\
1130 \\
0940 \\
1255\end{array}$ & $\begin{array}{l}331.10 \\
331.27 \\
331.15 \\
331.24 \\
331.15\end{array}$ & $\begin{array}{l}2,394.5 \\
2,394.3 \\
2,394.4 \\
2,394.4 \\
2,394.4\end{array}$ & $\begin{array}{l}S \\
S \\
S \\
S \\
S\end{array}$ & $\begin{array}{l}: \\
:\end{array}$ & $\begin{array}{l}\text { EMP } \\
\text { EMP } \\
\text { EMP } \\
\text { EMP } \\
\text { EMP }\end{array}$ \\
\hline & & & & & $\begin{array}{l}11-10-1994 \\
12-22-1994\end{array}$ & $\begin{array}{l}0930 \\
1025\end{array}$ & $\begin{array}{l}331.08 \\
331.17\end{array}$ & $\begin{array}{l}2,394.5 \\
2,394.4\end{array}$ & $\begin{array}{l}S \\
S\end{array}$ & - & $\begin{array}{l}\text { EMP } \\
\text { EMP }\end{array}$ \\
\hline
\end{tabular}


Table 5. Periodic measurements of water levels at monitoring sites in Yucca Mountain region for calendar year 1994-Continued

\begin{tabular}{|c|c|c|c|c|c|c|c|c|c|c|c|}
\hline \multirow[b]{2}{*}{$\begin{array}{c}\text { Site } \\
\text { number } \\
\text { (plate 1) }\end{array}$} & \multirow[b]{2}{*}{$\begin{array}{l}\text { U.S. Geological } \\
\text { Survey site } \\
\text { identification }\end{array}$} & \multirow[b]{2}{*}{ Site name } & \multirow[b]{2}{*}{$\begin{array}{c}\text { Land- } \\
\text { surface } \\
\text { altitude } \\
\text { (feet } \\
\text { above } \\
\text { sea } \\
\text { level) }\end{array}$} & \multirow{2}{*}{$\begin{array}{c}\text { Height of } \\
\text { measure- } \\
\text { ment } \\
\text { point } \\
\text { (feet } \\
\text { above } \\
\text { land } \\
\text { surface) }\end{array}$} & \multicolumn{7}{|c|}{ Water-level measurement } \\
\hline & & & & & Date & Time & $\begin{array}{l}\text { Depth } \\
\text { to water } \\
\text { (feet } \\
\text { below } \\
\text { land } \\
\text { surface) }\end{array}$ & $\begin{array}{c}\text { Altltude } \\
\text { of water } \\
\text { surface } \\
\text { (feet } \\
\text { above } \\
\text { sea level) }\end{array}$ & Method & $\begin{array}{l}\text { Site } \\
\text { status }\end{array}$ & $\begin{array}{l}\text { Data } \\
\text { source }\end{array}$ \\
\hline JF- 1 & 365116116233801 & UE-25 WT 15 & $3,553.8$ & 0.18 & $\begin{array}{l}01-31-1994 \\
02-28-1994 \\
03-28-1994 \\
04-29-1994 \\
05-26-1994\end{array}$ & $\begin{array}{l}1127 \\
1217 \\
1345 \\
1046 \\
1030\end{array}$ & $\begin{array}{l}1161.67 \\
1161.57 \\
1161.52 \\
1161.50 \\
1161.39\end{array}$ & $\begin{array}{l}2,392.1 \\
2,392.2 \\
2,392.3 \\
2,392.3 \\
2,392.4\end{array}$ & $\begin{array}{l}\text { S } \\
\text { S } \\
\text { S } \\
\text { S } \\
\text { S }\end{array}$ & $\begin{array}{l}- \\
- \\
-\end{array}$ & $\begin{array}{l}\text { SCP } \\
\text { SCP } \\
\text { SCP } \\
\text { SCP } \\
\text { SCP }\end{array}$ \\
\hline & & & & & $\begin{array}{l}06-07-1994 \\
07-15-1994 \\
08-15-1994 \\
09-28-1994 \\
10-13-1994\end{array}$ & $\begin{array}{l}1001 \\
0932 \\
1016 \\
1142 \\
.1232\end{array}$ & $\begin{array}{l}1161.43 \\
1161.51 \\
1161.47 \\
1161.51 \\
1161.16\end{array}$ & $\begin{array}{l}2,392.4 \\
2,392.3 \\
2,392.3 \\
2,392.3 \\
2,392.6\end{array}$ & $\begin{array}{l}\text { S } \\
\text { S } \\
\text { S } \\
\text { S } \\
\text { S }\end{array}$ & $\begin{array}{l}- \\
- \\
-\end{array}$ & $\begin{array}{l}\text { SCP } \\
\text { SCP } \\
\text { SCP } \\
\text { SCP } \\
\text { SCP }\end{array}$ \\
\hline & & & & & $\begin{array}{l}11-03-1994 \\
12-13-1994\end{array}$ & $\begin{array}{l}1107 \\
1140\end{array}$ & $\begin{array}{l}1161.38 \\
1161.37\end{array}$ & $\begin{array}{l}2,392.4 \\
2,392.4\end{array}$ & $\begin{array}{l}\mathrm{s} \\
\mathrm{s}\end{array}$ & - & $\begin{array}{l}\text { SCP } \\
\text { SCP }\end{array}$ \\
\hline JF- 2 & 364945116235001 & UE-25 WT 13 & $3,387.5$ & 1.00 & $\begin{array}{l}01-27-1994 \\
02-08-1994 \\
06-21-1994 \\
07-15-1994 \\
08-15-1994\end{array}$ & $\begin{array}{l}0948 \\
0935 \\
1109 \\
1000 \\
1047\end{array}$ & $\begin{array}{l}995.27 \\
994.93 \\
995.45 \\
995.35 \\
995.28\end{array}$ & $\begin{array}{l}2,392.2 \\
2,392.6 \\
2,392.0 \\
2,392.2 \\
2,392.2\end{array}$ & $\begin{array}{l}\text { S } \\
\text { S } \\
\text { S } \\
\text { S } \\
\text { S }\end{array}$ & $\begin{array}{l}- \\
- \\
-\end{array}$ & $\begin{array}{l}\text { SCP } \\
\text { SCP } \\
\text { SCP } \\
\text { SCP } \\
\text { SCP }\end{array}$ \\
\hline & & & & & $\begin{array}{l}09-28-1994 \\
10-13-1994 \\
11-03-1994 \\
12-29-1994\end{array}$ & $\begin{array}{l}1215 \\
1308 \\
1140 \\
1231\end{array}$ & $\begin{array}{l}995.37 \\
994.92 \\
995.21 \\
995.21\end{array}$ & $\begin{array}{l}2,392.1 \\
2,392.6 \\
2,392.3 \\
2,392.3\end{array}$ & $\begin{array}{l}\text { S } \\
\text { S } \\
\text { S } \\
\text { S }\end{array}$ & $:$ & $\begin{array}{l}\text { SCP } \\
\text { SCP } \\
\text { SCP } \\
\text { SCP }\end{array}$ \\
\hline$J F-2 a$ & 364938116252102 & UE-25p 1 PTH & $3,655.5$ & .56 & $\begin{array}{l}03-31-1994 \\
04-17-1994 \\
07-28-1994 \\
11-23-1994\end{array}$ & $\begin{array}{l}1029 \\
1112 \\
1153 \\
1527\end{array}$ & $\begin{array}{l}1,186.70 \\
1,186.61 \\
1,186.49 \\
1,186.74\end{array}$ & $\begin{array}{l}2,468.8 \\
2,468.9 \\
2,469.0 \\
2,468.8\end{array}$ & $\begin{array}{l}\text { S } \\
\text { B } \\
\text { B } \\
\text { B }\end{array}$ & 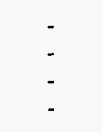 & $\begin{array}{l}\text { SCP } \\
\text { SCP } \\
\text { SCP } \\
\text { SCP }\end{array}$ \\
\hline $\mathrm{J}-13$ & 364828116234001 & $\mathrm{~J}-13 \mathrm{WW}$ & $3,317.9$ & 1.11 & $\begin{array}{l}01-14-1994 \\
02-10-1994 \\
03-01-1994 \\
03-15-1994 \\
03-24-1994\end{array}$ & $\begin{array}{l}1143 \\
0928 \\
0959 \\
0826 \\
1003\end{array}$ & $\begin{array}{l}928.12 \\
927.89 \\
928.29 \\
927.95 \\
928.08\end{array}$ & $\begin{array}{l}2,389.8 \\
2,390.0 \\
2,389.6 \\
2,390.0 \\
2,389.8\end{array}$ & $\begin{array}{l}\text { S } \\
\text { S } \\
\text { S } \\
\text { S } \\
\text { S }\end{array}$ & $\begin{array}{l}: \\
: \\
-\end{array}$ & $\begin{array}{l}\text { SCP } \\
\text { SCP } \\
\text { SCP } \\
\text { SCP } \\
\text { SCP }\end{array}$ \\
\hline & & & & & $\begin{array}{l}04-15-1994 \\
04-29-1994 \\
05-18-1994 \\
05-27-1994 \\
06-10-1994\end{array}$ & $\begin{array}{l}1009 \\
1148 \\
1144 \\
1029 \\
0810\end{array}$ & $\begin{array}{l}928.27 \\
928.34 \\
928.23 \\
928.09 \\
928.11\end{array}$ & $\begin{array}{l}2,389.6 \\
2,389.6 \\
2,389.7 \\
2,389.8 \\
2,389.8\end{array}$ & $\begin{array}{l}\mathbf{S} \\
\mathbf{S} \\
\mathbf{S} \\
\mathbf{S} \\
\mathbf{S}\end{array}$ & $\begin{array}{l}- \\
- \\
-\end{array}$ & $\begin{array}{l}\text { SCP } \\
\text { SCP } \\
\text { SCP } \\
\text { SCP } \\
\text { SCP }\end{array}$ \\
\hline & & & & & $\begin{array}{l}06-24-1994 \\
07-08-1994 \\
07-27-1994 \\
08-05-1994 \\
08-31-1994\end{array}$ & $\begin{array}{l}1026 \\
0814 \\
0918 \\
0853 \\
0907\end{array}$ & $\begin{array}{l}928.17 \\
928.22 \\
928.17 \\
928.28 \\
928.11\end{array}$ & $\begin{array}{l}2,389.7 \\
2,389.7 \\
2,389.7 \\
2,389.6 \\
2,389.8\end{array}$ & $\begin{array}{l}\mathbf{S} \\
\mathbf{S} \\
\mathbf{S} \\
\mathbf{S} \\
\mathbf{S}\end{array}$ & $\begin{array}{l}- \\
- \\
- \\
-\end{array}$ & $\begin{array}{l}\text { SCP } \\
\text { SCP } \\
\text { SCP } \\
\text { SCP } \\
\text { SCP }\end{array}$ \\
\hline
\end{tabular}


Table 5. Periodic measurements of water levels at monitoring sites in Yucca Mountain region for calendar year 1994-Continued

\begin{tabular}{|c|c|c|c|c|c|c|c|c|c|c|c|}
\hline \multirow[b]{2}{*}{$\begin{array}{c}\text { Site } \\
\text { number } \\
\text { (plate 1) }\end{array}$} & \multirow[b]{2}{*}{$\begin{array}{l}\text { U.S. Geological } \\
\text { Survey site } \\
\text { identification }\end{array}$} & \multirow[b]{2}{*}{ Site name } & \multirow{2}{*}{$\begin{array}{l}\text { Land- } \\
\text { surface } \\
\text { altitude } \\
\text { (feet } \\
\text { above } \\
\text { sea } \\
\text { level) }\end{array}$} & \multirow{2}{*}{$\begin{array}{l}\text { Height of } \\
\text { measure- } \\
\text { ment } \\
\text { point } \\
\text { (feet } \\
\text { above } \\
\text { land } \\
\text { surface) }\end{array}$} & \multicolumn{7}{|c|}{ Water-level measurement } \\
\hline & & & & & Date & Time & $\begin{array}{l}\text { Depth } \\
\text { to water } \\
\text { (feet } \\
\text { below } \\
\text { land } \\
\text { surface) }\end{array}$ & $\begin{array}{c}\text { Altitude } \\
\text { of water } \\
\text { surface } \\
\text { (feet } \\
\text { above } \\
\text { sea level) }\end{array}$ & Method & $\begin{array}{l}\text { Site } \\
\text { status }\end{array}$ & $\begin{array}{l}\text { Data } \\
\text { source }\end{array}$ \\
\hline \multirow[t]{2}{*}{$\mathrm{J}-13$} & 364828116234001 & $J-13 w W$ & $3,317.9$ & 1.11 & $\begin{array}{l}09-16-1994 \\
09-30-1994 \\
10-12-1994 \\
10-27-1994 \\
11-10-1994\end{array}$ & $\begin{array}{l}1018 \\
0737 \\
0843 \\
0947 \\
0811\end{array}$ & $\begin{array}{l}928.44 \\
927.95 \\
928.17 \\
928.30 \\
927.87\end{array}$ & $\begin{array}{l}2,389.5 \\
2,390.0 \\
2,389.7 \\
2,389.6 \\
2,390.0\end{array}$ & $\begin{array}{l}S \\
S \\
S \\
S \\
S\end{array}$ & $\begin{array}{l}- \\
- \\
-\end{array}$ & $\begin{array}{l}\text { SCP } \\
\text { SCP } \\
\text { SCP } \\
\text { SCP } \\
\text { SCP }\end{array}$ \\
\hline & & & & & $\begin{array}{l}11-29-1994 \\
12-13-1994 \\
12-29-1994\end{array}$ & $\begin{array}{l}0847 \\
0842 \\
1304\end{array}$ & $\begin{array}{l}928.47 \\
928.09 \\
927.89\end{array}$ & $\begin{array}{l}2,389.4 \\
2,389.8 \\
2,390.0\end{array}$ & $\begin{array}{l}S \\
S \\
S\end{array}$ & - & $\begin{array}{l}\text { SCP } \\
\text { SCP } \\
\text { SCP }\end{array}$ \\
\hline \multirow[t]{3}{*}{$\mathrm{J}-11$} & 364706116170601 & J-11 WW & $3,442.8$ & 2.11 & $\begin{array}{l}02-03-1994 \\
03-01-1994 \\
03-15-1994 \\
05-02-1994 \\
05-27-1994\end{array}$ & $\begin{array}{l}1202 \\
1326 \\
1109 \\
1155 \\
1106\end{array}$ & $\begin{array}{l}1,040.41 \\
1,040.77 \\
1,040.47 \\
1,040.53 \\
1,040.45\end{array}$ & $\begin{array}{l}2,402.4 \\
2,402.0 \\
2,402.3 \\
2,402.3 \\
2,402.4\end{array}$ & $\begin{array}{l}\text { S } \\
S \\
S \\
S \\
S\end{array}$ & $\begin{array}{l}- \\
- \\
-\end{array}$ & $\begin{array}{l}\text { SCP } \\
\text { SCP } \\
\text { SCP } \\
\text { SCP } \\
\text { SCP }\end{array}$ \\
\hline & & & & & $\begin{array}{l}06-24-1994 \\
07-27-1994 \\
09-06-1994 \\
09-30-1994 \\
10-27-1994\end{array}$ & $\begin{array}{l}1144 \\
1423 \\
1026 \\
1007 \\
1024\end{array}$ & $\begin{array}{l}1,040.51 \\
1,040.43 \\
1,040.60 \\
1,040.31 \\
1,040.64\end{array}$ & $\begin{array}{l}2,402.3 \\
2,402.4 \\
2,402.2 \\
2,402.5 \\
2,402.2\end{array}$ & $\begin{array}{l}\mathbf{S} \\
\mathbf{S} \\
\mathbf{S} \\
\mathbf{S} \\
\mathbf{S}\end{array}$ & $\begin{array}{l}- \\
- \\
-\end{array}$ & $\begin{array}{l}\text { SCP } \\
\text { SCP } \\
\text { SCP } \\
\text { SCP } \\
\text { SCP }\end{array}$ \\
\hline & & & & & $\begin{array}{l}12-02-1994 \\
12-08-1994\end{array}$ & $\begin{array}{l}1018 \\
1053\end{array}$ & $\begin{array}{l}1,040.31 \\
1,040.74\end{array}$ & $\begin{array}{l}2,402.5 \\
2,402.1\end{array}$ & $\begin{array}{l}\text { S } \\
\text { S }\end{array}$ & - & $\begin{array}{l}\text { SCP } \\
\text { SCP }\end{array}$ \\
\hline \multirow[t]{4}{*}{$J-12$} & 364554116232401 & $J-12 W W$ & $3,128.4$ & 5.04 & $\begin{array}{l}01-14-1994 \\
02-10-1994 \\
03-01-1994 \\
03-10-1994 \\
03-24-1994\end{array}$ & $\begin{array}{l}1154 \\
0858 \\
0932 \\
1258 \\
0940\end{array}$ & $\begin{array}{l}739.95 \\
740.13 \\
740.44 \\
740.10 \\
740.11\end{array}$ & $\begin{array}{l}2,388.4 \\
2,388.3 \\
2,388.0 \\
2,388.3 \\
2,388.3\end{array}$ & $\begin{array}{l}S \\
S \\
S \\
S \\
S\end{array}$ & $\begin{array}{l}- \\
: \\
-\end{array}$ & $\begin{array}{l}\text { SCP } \\
\text { SCP } \\
\text { SCP } \\
\text { SCP } \\
\text { SCP }\end{array}$ \\
\hline & & & & & $\begin{array}{l}04-15-1994 \\
04-29-1994 \\
05-05-1994 \\
05-16-1994 \\
05-27-1994\end{array}$ & $\begin{array}{l}0900 \\
1125 \\
0901 \\
1310 \\
0948\end{array}$ & $\begin{array}{l}740.38 \\
740.43 \\
740.06 \\
739.94 \\
740.18\end{array}$ & $\begin{array}{l}2,388.0 \\
2,388.0 \\
2,388.3 \\
2,388.5 \\
2,388.2\end{array}$ & $\begin{array}{l}S \\
S \\
S \\
S \\
S\end{array}$ & $\begin{array}{l}- \\
- \\
- \\
-\end{array}$ & $\begin{array}{l}\text { SCP } \\
\text { SCP } \\
\text { SCP } \\
\text { SCP } \\
\text { SCP }\end{array}$ \\
\hline & & & & & $\begin{array}{l}06-10-1994 \\
06-24-1994 \\
07-08-1994 \\
07-28-1994 \\
08-05-1994\end{array}$ & $\begin{array}{l}0739 \\
0955 \\
0735 \\
1223 \\
0824\end{array}$ & $\begin{array}{l}740.18 \\
740.19 \\
740.29 \\
740.29 \\
740.16\end{array}$ & $\begin{array}{l}2,388.2 \\
2,388.2 \\
2,388.1 \\
2,388.1 \\
2,388.2\end{array}$ & $\begin{array}{l}S \\
S \\
S \\
S \\
S\end{array}$ & $\begin{array}{l}- \\
- \\
- \\
-\end{array}$ & $\begin{array}{l}\text { SCP } \\
\text { SCP } \\
\text { SCP } \\
\text { SCP } \\
\text { SCP }\end{array}$ \\
\hline & & & & & $\begin{array}{l}08-31-1994 \\
09-16-1994 \\
09-30-1994 \\
10-11-1994 \\
10-27-1994\end{array}$ & $\begin{array}{l}0941 \\
0928 \\
0715 \\
1247 \\
0907\end{array}$ & $\begin{array}{l}740.28 \\
740.37 \\
740.18 \\
740.25 \\
740.46\end{array}$ & $\begin{array}{l}2,388.1 \\
2,388.0 \\
2,388.2 \\
2,388.2 \\
2,387.9\end{array}$ & $\begin{array}{l}S \\
S \\
S \\
S \\
S\end{array}$ & $\begin{array}{l}- \\
- \\
- \\
-\end{array}$ & $\begin{array}{l}\text { SCP } \\
\text { SCP } \\
\text { SCP } \\
\text { SCP } \\
\text { SCP }\end{array}$ \\
\hline
\end{tabular}


Table 5. Periodic measurements of water levels at monitoring sites in Yucca Mountain region for calendar year 1994—Continued

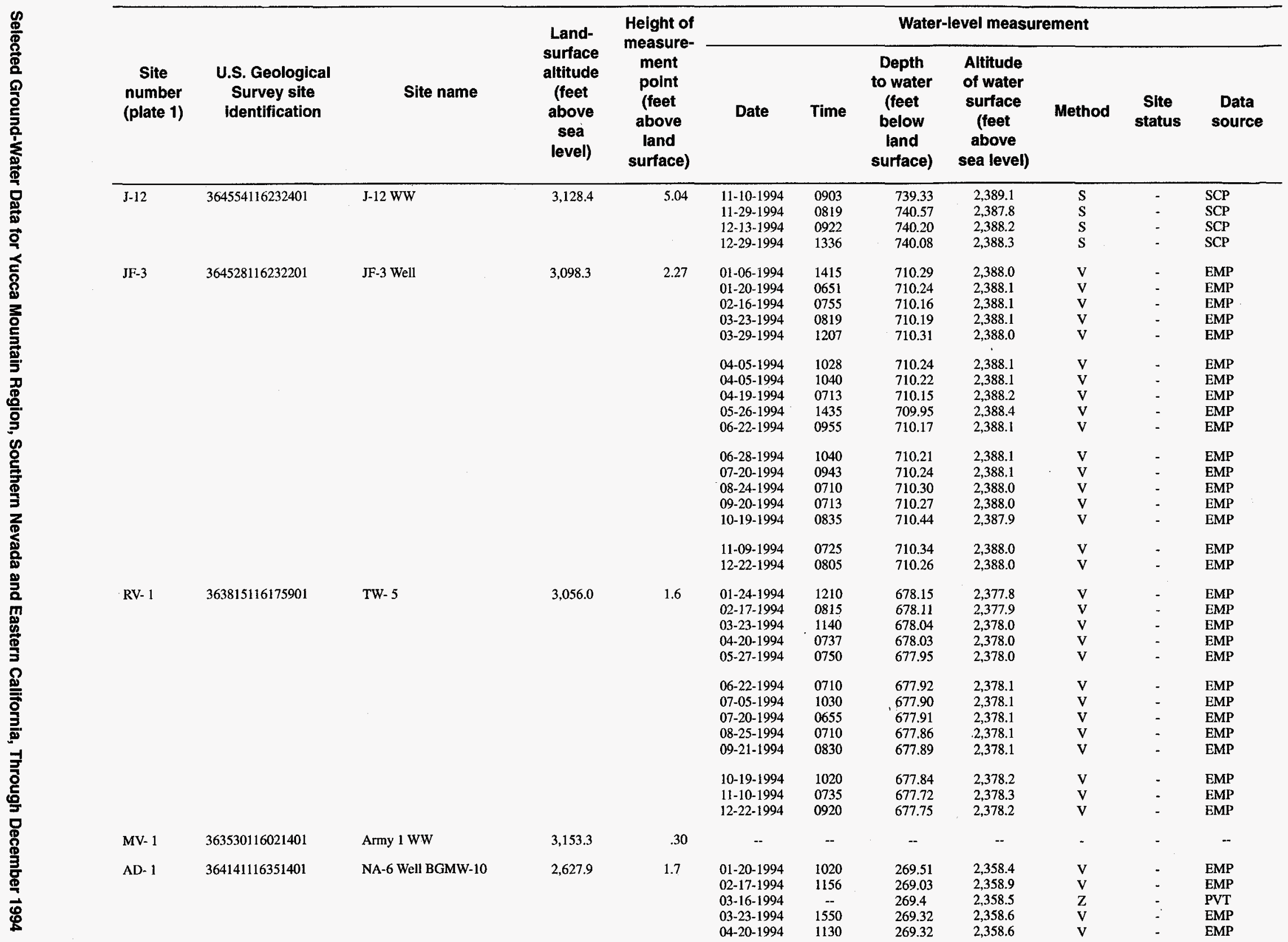


Table 5. Periodic measurements of water levels at monitoring sites in Yucca Mountain region for calendar year 1994—Continued

\begin{tabular}{|c|c|c|c|c|c|c|c|c|c|c|c|}
\hline \multirow[b]{2}{*}{$\begin{array}{c}\text { Site } \\
\text { number } \\
\text { (plate 1) }\end{array}$} & \multirow[b]{2}{*}{$\begin{array}{l}\text { U.S. Geological } \\
\text { Survey site } \\
\text { identification }\end{array}$} & \multirow[b]{2}{*}{ Site name } & \multirow{2}{*}{$\begin{array}{l}\text { Land- } \\
\text { surface } \\
\text { altitude } \\
\text { (feet } \\
\text { above } \\
\text { sea } \\
\text { level) }\end{array}$} & \multirow{2}{*}{$\begin{array}{l}\text { Height of } \\
\text { measure- } \\
\text { ment } \\
\text { point } \\
\text { (feet } \\
\text { above } \\
\text { land } \\
\text { surface) }\end{array}$} & \multicolumn{7}{|c|}{ Water-level measurement } \\
\hline & & & & & Date & Time & $\begin{array}{l}\text { Depth } \\
\text { to water } \\
\text { (feet } \\
\text { below } \\
\text { land } \\
\text { surface) }\end{array}$ & $\begin{array}{c}\text { Altitude } \\
\text { of water } \\
\text { surface } \\
\text { (feet } \\
\text { above } \\
\text { sea level) }\end{array}$ & Method & $\begin{array}{l}\text { Site } \\
\text { status }\end{array}$ & $\begin{array}{c}\text { Data } \\
\text { source }\end{array}$ \\
\hline \multirow[t]{2}{*}{ AD- 1} & 364141116351401 & NA-6 Well BGMW-10 & $2,627.9$ & 1.7 & $\begin{array}{l}05-27-1994 \\
06-21-1994 \\
06-22-1994 \\
07-20-1994 \\
08-29-1994\end{array}$ & $\begin{array}{l}1145 \\
\ddot{1402} \\
1325 \\
1425\end{array}$ & $\begin{array}{l}269.38 \\
269.6 \\
269.36 \\
269.38 \\
269.31\end{array}$ & $\begin{array}{l}2,358.5 \\
2,358.3 \\
2,358.5 \\
2,358.5 \\
2,358.6\end{array}$ & $\begin{array}{l}\text { V } \\
Z \\
V \\
V \\
V\end{array}$ & $\begin{array}{l}- \\
- \\
-\end{array}$ & $\begin{array}{l}\text { EMP } \\
\text { PVT } \\
\text { EMP } \\
\text { EMP } \\
\text { EMP }\end{array}$ \\
\hline & & & & & $\begin{array}{l}09-21-1994 \\
09-28-1994 \\
10-20-1994 \\
11-10-1994 \\
12-18-1994 \\
12-22-1994\end{array}$ & $\begin{array}{c}1310 \\
\overline{-} \\
1000 \\
1230 \\
\overline{-} \\
1325\end{array}$ & $\begin{array}{l}269.37 \\
269.5 \\
269.44 \\
269.13 \\
269.7 \\
269.33\end{array}$ & $\begin{array}{l}2,358.5 \\
2,358.4 \\
2,358.5 \\
2,358.8 \\
2,358.2 \\
2,358.6\end{array}$ & $\begin{array}{l}\mathrm{V} \\
\mathrm{Z} \\
\mathrm{V} \\
\mathrm{V} \\
\mathrm{Z} \\
\mathrm{V}\end{array}$ & $\begin{array}{l}- \\
- \\
- \\
-\end{array}$ & $\begin{array}{l}\text { EMP } \\
\text { PVT } \\
\text { EMP } \\
\text { EMP } \\
\text { PVT } \\
\text { EMP }\end{array}$ \\
\hline \multirow[t]{3}{*}{ AD- 2} & 363830116241401 & Airport Well & $2,638.8$ & 1.05 & $\begin{array}{l}01-19-1994 \\
02-15-1994 \\
03-22-1994 \\
04-19-1994 \\
05-19-1994\end{array}$ & $\begin{array}{l}1130 \\
1350 \\
0835 \\
1035 \\
1040\end{array}$ & $\begin{array}{l}324.56 \\
324.61 \\
324.32 \\
324.65 \\
324.77\end{array}$ & $\begin{array}{l}2,314.2 \\
2,314.2 \\
2,314.5 \\
2,314.2 \\
2,314.0\end{array}$ & $\begin{array}{l}\text { V } \\
\text { V } \\
\text { V } \\
\text { V } \\
\text { V }\end{array}$ & $\begin{array}{l}- \\
- \\
- \\
-\end{array}$ & $\begin{array}{l}\text { EMP } \\
\text { EMP } \\
\text { EMP } \\
\text { EMP } \\
\text { EMP }\end{array}$ \\
\hline & & & & & $\begin{array}{l}06-28-1994 \\
07-19-1994 \\
08-24-1994 \\
09-20-1994 \\
10-18-1994\end{array}$ & $\begin{array}{l}1150 \\
1155 \\
1350 \\
0820 \\
0730\end{array}$ & $\begin{array}{l}324.66 \\
324.72 \\
324.68 \\
324.70 \\
324.73\end{array}$ & $\begin{array}{l}2,314.1 \\
2,314.1 \\
2,314.1 \\
2,314.1 \\
2,314.1\end{array}$ & $\begin{array}{l}\mathrm{V} \\
\mathrm{V} \\
\mathrm{V} \\
\mathrm{V} \\
\mathrm{V}\end{array}$ & $\begin{array}{l}- \\
- \\
- \\
-\end{array}$ & $\begin{array}{l}\text { EMP } \\
\text { EMP } \\
\text { EMP } \\
\text { EMP } \\
\text { EMP }\end{array}$ \\
\hline & & & & & $\begin{array}{l}11-09-1994 \\
12-21-1994\end{array}$ & $\begin{array}{l}0805 \\
0935\end{array}$ & $\begin{array}{l}324.71 \\
324.75\end{array}$ & $\begin{array}{l}2,314.1 \\
2,314.0\end{array}$ & $\begin{array}{l}\mathrm{V} \\
\mathrm{V}\end{array}$ & - & $\begin{array}{l}\text { EMP } \\
\text { EMP }\end{array}$ \\
\hline \multirow[t]{3}{*}{ AD- $2 a$} & 363835116234001 & NDOT Well & $2,656.8$ & .4 & $\begin{array}{l}01-20-1994 \\
02-15-1994 \\
03-22-1994 \\
04-20-1994 \\
05-19-1994\end{array}$ & $\begin{array}{l}0603 \\
1407 \\
0755 \\
1240 \\
1100\end{array}$ & $\begin{array}{l}341.99 \\
342.02 \\
343.08 \\
344.23 \\
342.40\end{array}$ & $\begin{array}{l}2,314.8 \\
2,314.8 \\
2,313.7 \\
2,312.6 \\
2,314.4\end{array}$ & $\begin{array}{l}\text { V } \\
\text { V } \\
\text { V } \\
\text { S } \\
\text { S }\end{array}$ & $\begin{array}{l}- \\
\dot{R} \\
\mathrm{R} \\
\mathrm{R}\end{array}$ & $\begin{array}{l}\text { EMP } \\
\text { EMP } \\
\text { EMP } \\
\text { EMP } \\
\text { EMP }\end{array}$ \\
\hline & & & & & $\begin{array}{l}06-22-1994 \\
07-20-1994 \\
08-24-1994 \\
09-20-1994 \\
10-20-1994\end{array}$ & $\begin{array}{l}0855 \\
1410 \\
0750 \\
0750 \\
1045\end{array}$ & $\begin{array}{l}343.99 \\
342.34 \\
342.15 \\
342.72 \\
342.50\end{array}$ & $\begin{array}{l}2,312.8 \\
2,314.5 \\
2,314.6 \\
2,314.1 \\
2,314.3\end{array}$ & $\begin{array}{l}S \\
S \\
S \\
S \\
S\end{array}$ & $\begin{array}{l}\mathbf{P} \\
- \\
- \\
- \\
-\end{array}$ & $\begin{array}{l}\text { EMP } \\
\text { EMP } \\
\text { EMP } \\
\text { EMP } \\
\text { EMP }\end{array}$ \\
\hline & & & & & $\begin{array}{l}11-09-1994 \\
12-21-1994\end{array}$ & $\begin{array}{l}1300 \\
0900\end{array}$ & $\begin{array}{l}342.14 \\
342.17\end{array}$ & $\begin{array}{l}2,314.7 \\
2,314.6\end{array}$ & $\begin{array}{l}S \\
S\end{array}$ & $\mathrm{R}$ & $\begin{array}{l}\text { EMP } \\
\text { EMP }\end{array}$ \\
\hline AD- $3 \mathrm{a}$ & 363521116352501 & Davidson Well & $2,395.3$ & 1.00 & $\begin{array}{l}01-19-1994 \\
02-02-1994 \\
03-22-1994 \\
04-19-1994 \\
05-23-1994\end{array}$ & $\begin{array}{l}1025 \\
1240 \\
0940 \\
1155 \\
1435\end{array}$ & $\begin{array}{l}129.88 \\
129.71 \\
129.81 \\
130.02 \\
130.09\end{array}$ & $\begin{array}{l}2,265.4 \\
2,265.6 \\
2,265.5 \\
2,265.3 \\
2,265.2\end{array}$ & $\begin{array}{l}S \\
S \\
S \\
S \\
S\end{array}$ & $\begin{array}{l}- \\
- \\
- \\
-\end{array}$ & $\begin{array}{l}\text { EMP } \\
\text { EMP } \\
\text { EMP } \\
\text { EMP } \\
\text { EMP }\end{array}$ \\
\hline
\end{tabular}


Table 5. Periodic measurements of water levels at monitoring sites in Yucca Mountain region for calendar year 1994-Continued

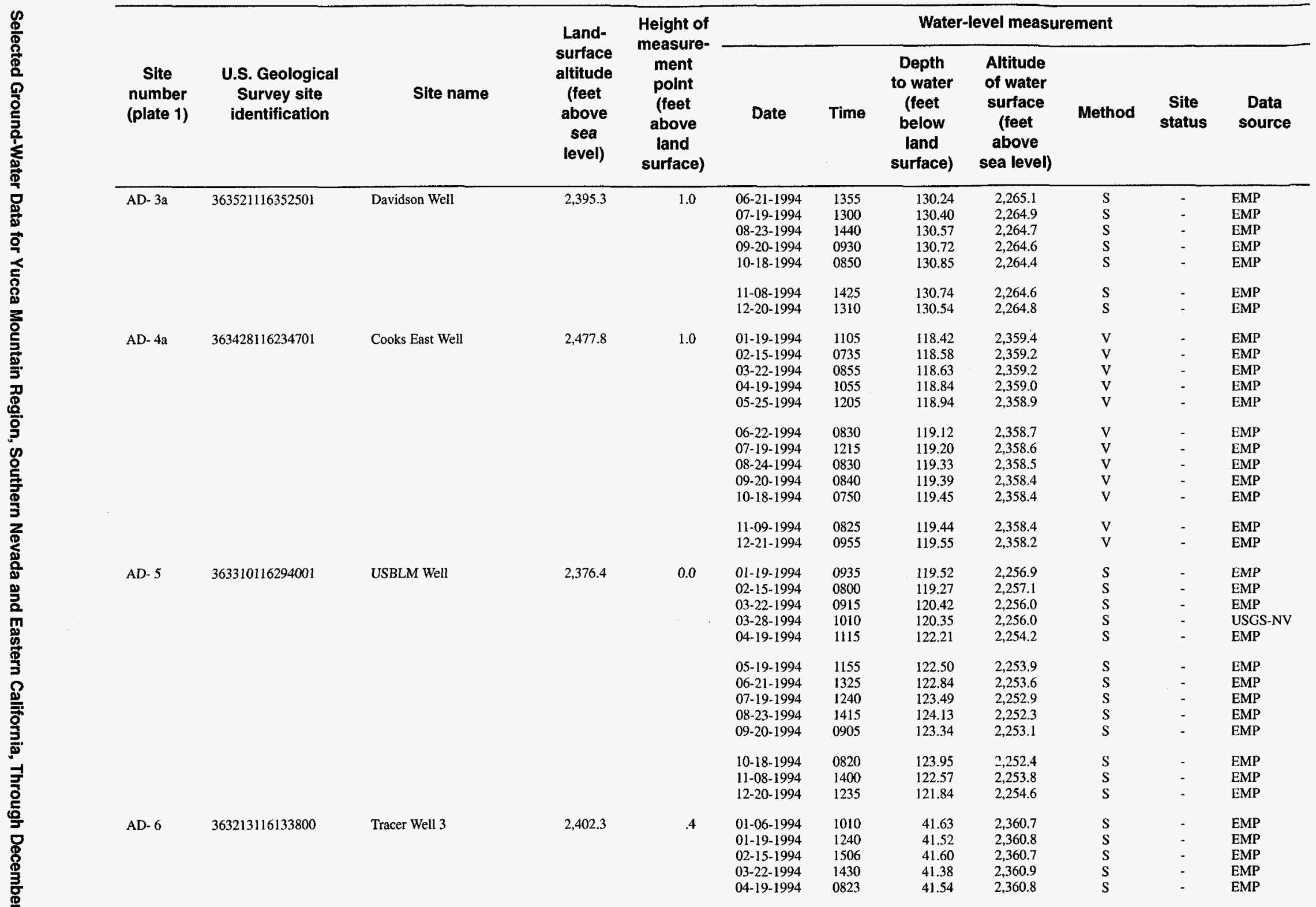


Table 5. Periodic measurements of water levels at monitoring sites in Yucca Mountain region for calendar year 1994—Continued

\begin{tabular}{|c|c|c|c|c|c|c|c|c|c|c|c|}
\hline \multirow[b]{2}{*}{$\begin{array}{c}\text { Site } \\
\text { number } \\
\text { (plate 1) }\end{array}$} & \multirow[b]{2}{*}{$\begin{array}{l}\text { U.S. Geological } \\
\text { Survey site } \\
\text { identification }\end{array}$} & \multirow[b]{2}{*}{ Site name } & \multirow[b]{2}{*}{$\begin{array}{l}\text { Land- } \\
\text { surface } \\
\text { altitude } \\
\text { (feet } \\
\text { above } \\
\text { sea } \\
\text { level) }\end{array}$} & \multirow{2}{*}{$\begin{array}{c}\text { Height of } \\
\text { measure- } \\
\text { ment } \\
\text { point } \\
\text { (feet } \\
\text { above } \\
\text { land } \\
\text { surface) }\end{array}$} & \multicolumn{7}{|c|}{ Water-level measurement } \\
\hline & & & & & Date & Time & $\begin{array}{l}\text { Depth } \\
\text { to water } \\
\text { (feet } \\
\text { below } \\
\text { land } \\
\text { surface) }\end{array}$ & $\begin{array}{c}\text { Altitude } \\
\text { of water } \\
\text { surface } \\
\text { (feet } \\
\text { above } \\
\text { sea level) }\end{array}$ & Method & $\begin{array}{c}\text { Site } \\
\text { status }\end{array}$ & $\begin{array}{l}\text { Data } \\
\text { source }\end{array}$ \\
\hline \multirow[t]{2}{*}{ AD- 6} & 363213116133800 & Tracer Well 3 & $2,402.3$ & 0.4 & $\begin{array}{l}05-25-1994 \\
06-10-1994 \\
07-20-1994 \\
08-16-1994 \\
09-21-1994\end{array}$ & $\begin{array}{l}1320 \\
1042 \\
0824 \\
1020 \\
0652\end{array}$ & $\begin{array}{l}41.58 \\
41.61 \\
41.65 \\
41.50 \\
41.59\end{array}$ & $\begin{array}{l}2,360.7 \\
2,360.7 \\
2,360.6 \\
2,360.8 \\
2,360.7\end{array}$ & $\begin{array}{l}S \\
S \\
S \\
S \\
S\end{array}$ & $\begin{array}{l}- \\
- \\
- \\
-\end{array}$ & $\begin{array}{l}\text { EMP } \\
\text { EMP } \\
\text { EMP } \\
\text { EMP } \\
\text { EMP }\end{array}$ \\
\hline & & & & & $\begin{array}{l}10-06-1994 \\
11-01-1994 \\
12-21-1994\end{array}$ & $\begin{array}{l}1035 \\
1303 \\
0805\end{array}$ & $\begin{array}{l}41.63 \\
41.45 \\
41.63\end{array}$ & $\begin{array}{l}2,360.7 \\
2,360.8 \\
2,360.7\end{array}$ & $\begin{array}{l}S \\
S \\
S\end{array}$ & $\begin{array}{l}- \\
-\end{array}$ & $\begin{array}{l}\text { EMP } \\
\text { EMP } \\
\text { EMP }\end{array}$ \\
\hline AD- 7 & 363009116302701 & Hallowell Well & $2,305.0$ & .2 & $\begin{array}{l}01-19-1994 \\
02-15-1994\end{array}$ & $\begin{array}{l}0915 \\
0825\end{array}$ & $\begin{array}{l}65.58 \\
64.39\end{array}$ & $\begin{array}{l}2,239.4 \\
2,240.6\end{array}$ & $\begin{array}{l}S \\
S\end{array}$ & - & $\begin{array}{l}\text { EMP } \\
\text { EMP }\end{array}$ \\
\hline AD- $7 \mathrm{a}$ & 363009116302702 & Blackman Well & $2,305.0$ & .78 & $\begin{array}{l}04-22-1994 \\
05-23-1994 \\
06-21-1994 \\
07-19-1994 \\
08-23-1994 \\
12-20-1994\end{array}$ & $\begin{array}{l}1005 \\
1405 \\
1255 \\
1330 \\
1345 \\
1340\end{array}$ & $\begin{array}{l}66.78 \\
67.23 \\
68.22 \\
68.91 \\
69.36 \\
66.46\end{array}$ & $\begin{array}{l}2,238.2 \\
2,237.8 \\
2,236.8 \\
2,236.1 \\
2,235.6 \\
2,238.5\end{array}$ & $\begin{array}{l}S \\
S \\
S \\
S \\
S \\
S\end{array}$ & $\begin{array}{l}- \\
- \\
- \\
- \\
-\end{array}$ & $\begin{array}{l}\text { EMP } \\
\text { EMP } \\
\text { EMP } \\
\text { EMP } \\
\text { EMP } \\
\text { EMP }\end{array}$ \\
\hline AD- 8 & 362929116085701 & Cherry Patch Well & $2,394.3$ & .6 & $\begin{array}{l}01-24-1994 \\
02-14-1994 \\
03-21-1994 \\
03-28-1994 \\
04-18-1994\end{array}$ & $\begin{array}{l}1100 \\
1015 \\
0940 \\
0925 \\
1025\end{array}$ & $\begin{array}{l}34.62 \\
33.53 \\
33.55 \\
33.49 \\
33.68\end{array}$ & $\begin{array}{l}2,359.7 \\
2,360.8 \\
2,360.8 \\
2,360.8 \\
2,360.6\end{array}$ & $\begin{array}{l}S \\
S \\
S \\
S \\
S\end{array}$ & $\begin{array}{l}- \\
- \\
-\end{array}$ & $\begin{array}{l}\text { EMP } \\
\text { EMP } \\
\text { EMP } \\
\text { USGS-NV } \\
\text { EMP }\end{array}$ \\
\hline & & & & & $\begin{array}{l}05-23-1994 \\
06-28-1994 \\
07-18-1994 \\
08-22-1994 \\
09-19-1994\end{array}$ & $\begin{array}{l}1030 \\
0820 \\
1020 \\
1040 \\
1025\end{array}$ & $\begin{array}{l}33.78 \\
34.75 \\
33.99 \\
35.04 \\
34.26\end{array}$ & $\begin{array}{l}2,360.5 \\
2,359.6 \\
2,360.3 \\
2,359.3 \\
2,360.0\end{array}$ & $\begin{array}{l}S \\
S \\
S \\
S \\
S\end{array}$ & $\begin{array}{l}- \\
- \\
- \\
-\end{array}$ & $\begin{array}{l}\text { EMP } \\
\text { EMP } \\
\text { EMP } \\
\text { EMP } \\
\text { EMP }\end{array}$ \\
\hline & & & & & $\begin{array}{l}10-18-1994 \\
11-07-1994 \\
12-19-1994\end{array}$ & $\begin{array}{l}0630 \\
1140 \\
0940\end{array}$ & $\begin{array}{l}33.35 \\
34.30 \\
34.99\end{array}$ & $\begin{array}{l}2,361.0 \\
2,360.0 \\
2,359.3\end{array}$ & $\begin{array}{l}\mathrm{S} \\
\mathrm{S} \\
\mathrm{S}\end{array}$ & $\begin{array}{l}- \\
-\end{array}$ & $\begin{array}{l}\text { EMP } \\
\text { EMP } \\
\text { EMP }\end{array}$ \\
\hline AD- 9 & 362848116264201 & Gilgans North Well & $2,264.8$ & -.1 & $\begin{array}{l}01-19-1994 \\
02-15-1994 \\
03-16-1994 \\
03-22-1994 \\
03-28-1994\end{array}$ & $\begin{array}{c}0754 \\
0845 \\
-- \\
1025 \\
1022\end{array}$ & $\begin{array}{l}72.77 \\
72.89 \\
75.58 \\
75.10 \\
75.38\end{array}$ & $\begin{array}{l}2,192.0 \\
2,191.9 \\
2,189.2 \\
2,189.7 \\
2,189.4\end{array}$ & $\begin{array}{l}S \\
S \\
Z \\
S \\
S\end{array}$ & $\begin{array}{l}- \\
- \\
- \\
-\end{array}$ & $\begin{array}{l}\text { EMP } \\
\text { EMP } \\
\text { NDWR } \\
\text { EMP } \\
\text { NTS }\end{array}$ \\
\hline & & & & & $\begin{array}{l}04-19-1994 \\
05-23-1994 \\
06-21-1994 \\
07-19-1994 \\
08-22-1994\end{array}$ & $\begin{array}{l}1225 \\
1345 \\
1150 \\
1345 \\
1505\end{array}$ & $\begin{array}{l}78.04 \\
78.63 \\
81.35 \\
80.85 \\
81.40\end{array}$ & $\begin{array}{l}2,186.8 \\
2,186.2 \\
2,183.4 \\
2,184.0 \\
2,183.4\end{array}$ & $\begin{array}{l}S \\
S \\
S \\
S \\
S\end{array}$ & $\begin{array}{l}- \\
- \\
-\end{array}$ & $\begin{array}{l}\text { EMP } \\
\text { EMP } \\
\text { EMP } \\
\text { EMP } \\
\text { EMP }\end{array}$ \\
\hline
\end{tabular}


Table 5. Periodic measurements of water levels at monitoring sites in Yucca Mountain region for calendar year 1994-Continued

\begin{tabular}{|c|c|c|c|c|c|c|c|c|c|c|c|}
\hline \multirow[b]{2}{*}{$\begin{array}{c}\text { Site } \\
\text { number } \\
\text { (plate 1) }\end{array}$} & \multirow[b]{2}{*}{$\begin{array}{l}\text { U.S. Geological } \\
\text { Survey site } \\
\text { identification }\end{array}$} & \multirow[b]{2}{*}{ Site name } & \multirow{2}{*}{$\begin{array}{c}\text { Land- } \\
\text { surface } \\
\text { altitude } \\
\text { (feet } \\
\text { above } \\
\text { sea } \\
\text { level) }\end{array}$} & \multirow{2}{*}{$\begin{array}{c}\text { Height of } \\
\text { measure- } \\
\text { ment } \\
\text { point } \\
\text { (feet } \\
\text { above } \\
\text { land } \\
\text { surface) }\end{array}$} & \multicolumn{7}{|c|}{ Water-level measurement } \\
\hline & & & & & Date & Time & $\begin{array}{l}\text { Depth } \\
\text { to water } \\
\text { (feet } \\
\text { below } \\
\text { land } \\
\text { surface) }\end{array}$ & $\begin{array}{c}\text { Altitude } \\
\text { of water } \\
\text { surface } \\
\text { (feet } \\
\text { above } \\
\text { sea level) }\end{array}$ & Method & $\begin{array}{c}\text { Site } \\
\text { status }\end{array}$ & $\begin{array}{c}\text { Data } \\
\text { source }\end{array}$ \\
\hline AD-9 & 362848116264201 & Gilgans North Well & $2,264.8$ & -0.1 & $\begin{array}{l}\text { 09-20-1994 } \\
10-18-1994 \\
11-08-1994 \\
12-20-1994\end{array}$ & $\begin{array}{l}1015 \\
0935 \\
1330 \\
1400\end{array}$ & $\begin{array}{l}80.15 \\
77.11 \\
75.50 \\
77.00\end{array}$ & $\begin{array}{l}2,184.6 \\
2,187.7 \\
2,189.3 \\
2,187.8\end{array}$ & $\begin{array}{l}\mathrm{S} \\
\mathrm{S} \\
\mathrm{S} \\
\mathrm{S}\end{array}$ & : & $\begin{array}{l}\text { EMP } \\
\text { EMP } \\
\text { EMP } \\
\text { EMP }\end{array}$ \\
\hline \multirow[t]{3}{*}{ AD-10 } & 362525116274301 & NA-9 Well & $2,190.9$ & 1.3 & $\begin{array}{l}01-19-1994 \\
02-15-1994 \\
03-21-1994 \\
04-19-1994 \\
05-23-1994\end{array}$ & $\begin{array}{l}0728 \\
0915 \\
1430 \\
1255 \\
1315\end{array}$ & $\begin{array}{l}9.34 \\
9.01 \\
9.15 \\
9.37 \\
9.54\end{array}$ & $\begin{array}{l}2,181.6 \\
2,181.9 \\
2,181.8 \\
2,181.5 \\
2,181.4\end{array}$ & $\begin{array}{l}\mathrm{S} \\
\mathrm{S} \\
\mathrm{S} \\
\mathrm{S} \\
\mathrm{S}\end{array}$ & $\begin{array}{l}- \\
- \\
-\end{array}$ & $\begin{array}{l}\text { EMP } \\
\text { EMP } \\
\text { EMP } \\
\text { EMP } \\
\text { EMP }\end{array}$ \\
\hline & & & & & $\begin{array}{l}06-20-1994 \\
07-18-1994 \\
08-22-1994 \\
09-20-1994 \\
10-18-1994\end{array}$ & $\begin{array}{l}1220 \\
1400 \\
1440 \\
1050 \\
0955\end{array}$ & $\begin{array}{l}9.63 \\
9.66 \\
9.67 \\
9.66 \\
9.80\end{array}$ & $\begin{array}{l}2,181.3 \\
2,181.2 \\
2,181.2 \\
2,181.2 \\
2,181.1\end{array}$ & $\begin{array}{l}\mathrm{S} \\
\mathrm{S} \\
\mathrm{S} \\
\mathrm{S} \\
\mathrm{S}\end{array}$ & $\begin{array}{l}- \\
- \\
-\end{array}$ & $\begin{array}{l}\text { EMP } \\
\text { EMP } \\
\text { EMP } \\
\text { EMP } \\
\text { EMP }\end{array}$ \\
\hline & & & & & $\begin{array}{l}11-08-1994 \\
12-21-1994\end{array}$ & $\begin{array}{l}1250 \\
1025\end{array}$ & $\begin{array}{l}9.78 \\
9.74\end{array}$ & $\begin{array}{l}2,181.1 \\
2,181.2\end{array}$ & $\begin{array}{l}\mathrm{s} \\
\mathrm{s}\end{array}$ & - & $\begin{array}{l}\text { EMP } \\
\text { EMP }\end{array}$ \\
\hline \multirow[t]{3}{*}{ AD-11 } & 361954116181201 & GS-3 Well & 2.351 .3 & 1.1 & $\begin{array}{l}01-18-1994 \\
02-14-1944 \\
03-21-1994 \\
04-18-1994 \\
05-19-1994\end{array}$ & $\begin{array}{l}1220 \\
1200 \\
1130 \\
1210 \\
1430\end{array}$ & $\begin{array}{l}225.00 \\
225.08 \\
225.05 \\
225.02 \\
224.90\end{array}$ & $\begin{array}{l}2,126.3 \\
2,126.2 \\
2,126.2 \\
2,126.3 \\
2,126.4\end{array}$ & $\begin{array}{l}\mathrm{S} \\
\mathrm{S} \\
\mathrm{S} \\
\mathrm{S} \\
\mathrm{S}\end{array}$ & $\begin{array}{l}: \\
\vdots\end{array}$ & $\begin{array}{l}\text { EMP } \\
\text { EMP } \\
\text { EMP } \\
\text { EMP } \\
\text { EMP }\end{array}$ \\
\hline & & & & & $\begin{array}{l}06-20-1994 \\
07-18-1994 \\
08-22-1994 \\
09-19-1994 \\
10-17-1994\end{array}$ & $\begin{array}{l}1025 \\
1215 \\
1225 \\
1205 \\
1240\end{array}$ & $\begin{array}{l}224.92 \\
224.72 \\
224.00 \\
224.64 \\
224.65\end{array}$ & $\begin{array}{l}2,126.4 \\
2,126.6 \\
2,127.3 \\
2,126.7 \\
2,126.6\end{array}$ & $\begin{array}{l}\mathrm{S} \\
\mathrm{S} \\
\mathrm{S} \\
\mathrm{S} \\
\mathrm{S}\end{array}$ & $\begin{array}{l}- \\
- \\
-\end{array}$ & $\begin{array}{l}\text { EMP } \\
\text { EMP } \\
\text { EMP } \\
\text { EMP } \\
\text { EMP }\end{array}$ \\
\hline & & & & & $\begin{array}{l}11-07-1994 \\
12-19-1994\end{array}$ & $\begin{array}{l}1330 \\
1140\end{array}$ & $\begin{array}{l}224.63 \\
224.93\end{array}$ & $\begin{array}{l}2,126.7 \\
2,126.4\end{array}$ & $\begin{array}{l}S \\
S\end{array}$ & - & $\begin{array}{l}\text { EMP } \\
\text { EMP }\end{array}$ \\
\hline \multirow[t]{2}{*}{ AD-12 } & 362014116133901 & GS-1 Well & $2,430.3$ & 2.0 & $\begin{array}{l}01-18-1994 \\
02-14-1994 \\
03-21-1994 \\
03-28-1994 \\
04-06-1994\end{array}$ & $\begin{array}{l}1130 \\
1125 \\
1030 \\
0881 \\
0750\end{array}$ & $\begin{array}{l}80.41 \\
80.38 \\
80.34 \\
80.39 \\
80.29\end{array}$ & $\begin{array}{l}2,349.9 \\
2,349.9 \\
2,350.0 \\
2,349.9 \\
2,350.0\end{array}$ & $\begin{array}{l}\mathrm{S} \\
\mathrm{S} \\
\mathrm{S} \\
\mathrm{S} \\
\mathrm{S}\end{array}$ & $\begin{array}{l}: \\
\vdots\end{array}$ & $\begin{array}{l}\text { EMP } \\
\text { EMP } \\
\text { EMP } \\
\text { NTS } \\
\text { NTS }\end{array}$ \\
\hline & & & & & $\begin{array}{c}04-18-1994 \\
05-23-1994 \\
06-10-1994 \\
06-17-1994 \\
07-01-1994\end{array}$ & $\begin{array}{l}1140 \\
1145 \\
1525 \\
0833 \\
1632\end{array}$ & $\begin{array}{l}80.30 \\
80.28 \\
80.35 \\
80.32 \\
80.32\end{array}$ & $\begin{array}{l}2,350.0 \\
2,3550.0 \\
2,350.0 \\
2,350.0 \\
2,350.0\end{array}$ & $\begin{array}{l}\mathrm{S} \\
\mathrm{S} \\
\mathrm{S} \\
\mathrm{S} \\
\mathrm{S}\end{array}$ & $\begin{array}{l}- \\
: \\
-\end{array}$ & $\begin{array}{l}\text { EMP } \\
\text { EMP } \\
\text { NTS } \\
\text { NTS } \\
\text { NTS }\end{array}$ \\
\hline
\end{tabular}


Table 5. Periodic measurements of water levels at monitoring sites in Yucca Mountain region for calendar year 1994-Continued

\begin{tabular}{|c|c|c|c|c|c|c|c|c|c|c|c|}
\hline \multirow[b]{2}{*}{$\begin{array}{c}\text { Site } \\
\text { number } \\
\text { (plate 1) }\end{array}$} & \multirow[b]{2}{*}{$\begin{array}{l}\text { U.S. Geological } \\
\text { Survey site } \\
\text { identification }\end{array}$} & \multirow[b]{2}{*}{ Site name } & \multirow[b]{2}{*}{$\begin{array}{l}\text { Land- } \\
\text { surface } \\
\text { altitude } \\
\text { (feet } \\
\text { above } \\
\text { sea } \\
\text { level) }\end{array}$} & \multirow{2}{*}{$\begin{array}{l}\text { Height of } \\
\text { measure- } \\
\text { ment } \\
\text { point } \\
\text { (feet } \\
\text { above } \\
\text { land } \\
\text { surface) }\end{array}$} & \multicolumn{7}{|c|}{ Water-level measurement } \\
\hline & & & & & Date & Time & $\begin{array}{l}\text { Depth } \\
\text { to water } \\
\text { (feet } \\
\text { below } \\
\text { land } \\
\text { surface) }\end{array}$ & $\begin{array}{c}\text { Altitude } \\
\text { of water } \\
\text { surface } \\
\text { (feet } \\
\text { above } \\
\text { sea level) }\end{array}$ & Method & $\begin{array}{c}\text { Site } \\
\text { status }\end{array}$ & $\begin{array}{l}\text { Data } \\
\text { source }\end{array}$ \\
\hline \multirow[t]{2}{*}{ AD-12 } & 362014116133901 & GS-I Well & $2,430.3$ & 2.0 & $\begin{array}{l}07-18-1994 \\
08-22-1994 \\
09-12-1994 \\
09-19-1994 \\
10-17-1994\end{array}$ & $\begin{array}{l}1130 \\
1150 \\
0708 \\
1135 \\
1210\end{array}$ & $\begin{array}{l}80.29 \\
80.26 \\
80.29 \\
80.30 \\
80.30\end{array}$ & $\begin{array}{l}2,350.0 \\
2,350.0 \\
2,350.0 \\
2,350.0 \\
2,350.0\end{array}$ & $\begin{array}{l}S \\
S \\
S \\
S \\
S\end{array}$ & $\begin{array}{l}- \\
- \\
- \\
-\end{array}$ & $\begin{array}{l}\text { EMP } \\
\text { EMP } \\
\text { NTS } \\
\text { EMP } \\
\text { EMP }\end{array}$ \\
\hline & & & & & $\begin{array}{l}11-07-1994 \\
12-19-1994\end{array}$ & $\begin{array}{l}1300 \\
1112\end{array}$ & $\begin{array}{l}80.24 \\
80.54\end{array}$ & $\begin{array}{l}2,350.1 \\
2,349.8\end{array}$ & $\begin{array}{l}S \\
S\end{array}$ & - & $\begin{array}{l}\text { EMP } \\
\text { EMP }\end{array}$ \\
\hline \multirow[t]{3}{*}{ AD-13 } & 361724116324201 & S-1 Well & $2,703.2$ & 2.0 & $\begin{array}{l}01-18-1994 \\
02-14-1994 \\
03-21-1994 \\
04-18-1994 \\
05-19-1994\end{array}$ & $\begin{array}{l}1333 \\
1309 \\
1240 \\
1310 \\
1315\end{array}$ & $\begin{array}{l}382.04 \\
382.00 \\
381.66 \\
381.48 \\
381.10\end{array}$ & $\begin{array}{l}2,321.2 \\
2,321.2 \\
2,321.5 \\
2,321.7 \\
2,322.1\end{array}$ & $\begin{array}{l}\text { V } \\
\text { V } \\
\text { V } \\
\text { V } \\
\text { S }\end{array}$ & $\begin{array}{l}- \\
- \\
-\end{array}$ & $\begin{array}{l}\text { EMP } \\
\text { EMP } \\
\text { EMP } \\
\text { EMP } \\
\text { EMP }\end{array}$ \\
\hline & & & & & $\begin{array}{l}06-20-1994 \\
07-18-1994 \\
08-22-1994 \\
09-19-1994 \\
10-17-1994\end{array}$ & $\begin{array}{l}1135 \\
1315 \\
1345 \\
1320 \\
1410\end{array}$ & $\begin{array}{l}380.83 \\
380.86 \\
380.68 \\
380.44 \\
380.62\end{array}$ & $\begin{array}{l}2,322.4 \\
2,322.3 \\
2,322.5 \\
2,322.8 \\
2,322.6\end{array}$ & $\begin{array}{l}\mathrm{v} \\
\mathrm{v} \\
\mathrm{v} \\
\mathrm{V} \\
\mathrm{V}\end{array}$ & $\begin{array}{l}- \\
- \\
- \\
-\end{array}$ & $\begin{array}{l}\text { EMP } \\
\text { EMP } \\
\text { EMP } \\
\text { EMP } \\
\text { EMP }\end{array}$ \\
\hline & & & & & $\begin{array}{l}11-07-1994 \\
12-19-1994\end{array}$ & $\begin{array}{l}1505 \\
1255\end{array}$ & $\begin{array}{l}380.72 \\
381.43\end{array}$ & $\begin{array}{l}2,322.5 \\
2,321.8\end{array}$ & $\begin{array}{l}\mathrm{V} \\
\mathrm{V}\end{array}$ & - & $\begin{array}{l}\text { EMP } \\
\text { EMP }\end{array}$ \\
\hline \multirow[t]{3}{*}{ AD-14 } & 361817116244701 & Death Valley Jct Well & $2,041.8$ & .7 & $\begin{array}{l}01-18-1994 \\
02-14-1994 \\
03-21-1994 \\
03-28-1994 \\
04-18-1994\end{array}$ & $\begin{array}{l}1308 \\
1235 \\
1210 \\
0947 \\
1240\end{array}$ & $\begin{array}{l}3.87 \\
3.70 \\
3.63 \\
3.58 \\
3.80\end{array}$ & $\begin{array}{l}2,037.9 \\
2,038.1 \\
2,038.2 \\
2,038.2 \\
2,038.0\end{array}$ & $\begin{array}{l}S \\
S \\
S \\
S \\
S\end{array}$ & $\begin{array}{l}- \\
- \\
-\end{array}$ & $\begin{array}{l}\text { EMP } \\
\text { EMP } \\
\text { EMP } \\
\text { NTS } \\
\text { EMP }\end{array}$ \\
\hline & & & & & $\begin{array}{l}05-23-1994 \\
06-20-1994 \\
07-18-1994 \\
08-22-1994 \\
09-19-1994\end{array}$ & $\begin{array}{l}1235 \\
1100 \\
1250 \\
1305 \\
1255\end{array}$ & $\begin{array}{l}3.94 \\
4.10 \\
4.20 \\
4.35 \\
4.11\end{array}$ & $\begin{array}{l}2,037.9 \\
2,037.7 \\
2,037.6 \\
2,037.4 \\
2,037.7\end{array}$ & $\begin{array}{l}S \\
S \\
S \\
S \\
S\end{array}$ & $\begin{array}{l}- \\
- \\
- \\
-\end{array}$ & $\begin{array}{l}\text { EMP } \\
\text { EMP } \\
\text { EMP } \\
\text { EMP } \\
\text { EMP }\end{array}$ \\
\hline & & & & & $\begin{array}{l}10-17-1994 \\
11-07-1994 \\
12-19-1994\end{array}$ & $\begin{array}{l}1320 \\
1430 \\
1225\end{array}$ & $\begin{array}{l}4.18 \\
4.03 \\
3.90\end{array}$ & $\begin{array}{l}2,037.6 \\
2,037.8 \\
2,037.9\end{array}$ & $\begin{array}{l}S \\
S \\
S\end{array}$ & $:$ & $\begin{array}{l}\text { EMP } \\
\text { EMP } \\
\text { EMP }\end{array}$ \\
\hline AM- 1 & 362858116195301 & Rogers Spring Well & $2,265.9$ & .1 & $\begin{array}{l}01-19-1994 \\
01-25-1994 \\
02-15-1994 \\
02-28-1994 \\
03-22-1994\end{array}$ & $\begin{array}{c}1600 \\
-- \\
1010 \\
-- \\
1200\end{array}$ & $\begin{array}{l}2.71 \\
2.69 \\
2.69 \\
2.70 \\
2.68\end{array}$ & $\begin{array}{l}2,263.2 \\
2,263.2 \\
2,263.2 \\
2,263.2 \\
2,263.2\end{array}$ & $\begin{array}{l}S^{\circ} \\
S \\
S \\
S \\
S\end{array}$ & $\begin{array}{l}- \\
-\end{array}$ & $\begin{array}{l}\text { EMP } \\
\text { USFWS } \\
\text { EMP } \\
\text { USFWS } \\
\text { EMP }\end{array}$ \\
\hline
\end{tabular}


Table 5. Periodic measurements of water levels at monitoring sites in Yucca Mountain region for calendar year 1994-Continued

\begin{tabular}{|c|c|c|c|c|c|c|c|c|c|c|c|}
\hline \multirow[b]{2}{*}{$\begin{array}{c}\text { Site } \\
\text { number } \\
\text { (plate 1) }\end{array}$} & \multirow[b]{2}{*}{$\begin{array}{l}\text { U.S. Geological } \\
\text { Survey site } \\
\text { identification }\end{array}$} & \multirow[b]{2}{*}{ Site name } & \multirow[b]{2}{*}{$\begin{array}{c}\text { Land- } \\
\text { surface } \\
\text { altitude } \\
\text { (feet } \\
\text { above } \\
\text { sea } \\
\text { level) }\end{array}$} & \multirow{2}{*}{$\begin{array}{c}\text { Height of } \\
\text { measure- } \\
\text { ment } \\
\text { point } \\
\text { (feet } \\
\text { above } \\
\text { land } \\
\text { surface) }\end{array}$} & \multicolumn{7}{|c|}{ Water-level measurement } \\
\hline & & & & & Date & Time & $\begin{array}{l}\text { Depth } \\
\text { to water } \\
\text { (feet } \\
\text { below } \\
\text { land } \\
\text { surface) }\end{array}$ & $\begin{array}{c}\text { Altitude } \\
\text { of water } \\
\text { surface } \\
\text { (feet } \\
\text { above } \\
\text { sea level) }\end{array}$ & Method & $\begin{array}{l}\text { Site } \\
\text { status }\end{array}$ & $\begin{array}{c}\text { Data } \\
\text { source }\end{array}$ \\
\hline \multirow[t]{6}{*}{ AM- 1} & 362858116195301 & Rogers Spring Well & $2,265.9$ & 0.1 & $\begin{array}{l}03-30-1994 \\
04-07-1994 \\
04-19-1994 \\
04-29-1994 \\
05-25-1994\end{array}$ & $\begin{array}{c}-- \\
1129 \\
1335 \\
-- \\
1055\end{array}$ & $\begin{array}{l}2.72 \\
2.73 \\
2.78 \\
2.83 \\
3.02\end{array}$ & $\begin{array}{l}, 263.2 \\
2,263.2 \\
2,263.1 \\
2,263.1 \\
2,262.9\end{array}$ & $\begin{array}{l}\mathrm{S} \\
\mathrm{S} \\
\mathrm{S} \\
\mathrm{S} \\
\mathrm{S}\end{array}$ & $\begin{array}{l}\overline{-} \\
- \\
-\end{array}$ & $\begin{array}{l}\text { USFWS } \\
\text { NTS } \\
\text { EMP } \\
\text { USFWS } \\
\text { EMP }\end{array}$ \\
\hline & & & & & $\begin{array}{l}05-31-1994 \\
06-17-1994 \\
06-21-1994 \\
06-28-1994 \\
07-01-1994\end{array}$ & $\begin{array}{r}-- \\
1146 \\
1045 \\
-- \\
0800\end{array}$ & $\begin{array}{l}3.17 \\
3.40 \\
3.50 \\
3.66 \\
3.72\end{array}$ & $\begin{array}{l}2,262.7 \\
2,262.5 \\
2,262.4 \\
2,262.2 \\
2,262.2\end{array}$ & $\begin{array}{l}\mathrm{S} \\
\mathrm{S} \\
\mathrm{S} \\
\mathrm{S} \\
\mathrm{S}\end{array}$ & $\begin{array}{l}: \\
: \\
-\end{array}$ & $\begin{array}{l}\text { USFWS } \\
\text { NTS } \\
\text { EMP } \\
\text { USFWS } \\
\text { NTS }\end{array}$ \\
\hline & & & & & $\begin{array}{l}07-19-1994 \\
07-26-194 \\
08-02-1994 \\
08-24-1994 \\
08-30-1994\end{array}$ & $\begin{array}{c}0905 \\
-- \\
1030 \\
1125 \\
--\end{array}$ & $\begin{array}{l}4.03 \\
4.08 \\
4.20 \\
4.34 \\
4.36\end{array}$ & $\begin{array}{l}2,261.9 \\
2,261.8 \\
2,261.7 \\
2,261.6 \\
2,261.5\end{array}$ & $\begin{array}{l}\mathrm{S} \\
\mathrm{S} \\
\mathrm{S} \\
\mathrm{S} \\
\mathrm{S}\end{array}$ & $\begin{array}{l}- \\
- \\
-\end{array}$ & $\begin{array}{l}\text { EMP } \\
\text { USFWS } \\
\text { NTS } \\
\text { EMP } \\
\text { USFWS }\end{array}$ \\
\hline & & & & & $\begin{array}{l}09-12-1994 \\
09-20-1994 \\
09-29-1994 \\
10-18-1994 \\
10-21-1994\end{array}$ & $\begin{array}{r}1840 \\
1150 \\
-- \\
115 \\
1028\end{array}$ & $\begin{array}{l}4.29 \\
4.12 \\
3.94 \\
3.62 \\
3.55\end{array}$ & $\begin{array}{l}2,261.6 \\
2,261.8 \\
2,262.0 \\
2,262.3 \\
2,262.4\end{array}$ & $\begin{array}{l}\text { S } \\
\text { S } \\
\text { S } \\
\text { S } \\
\text { S }\end{array}$ & $\begin{array}{l}- \\
- \\
-\end{array}$ & $\begin{array}{l}\text { NTS } \\
\text { EMP } \\
\text { USFW } \\
\text { EMP } \\
\text { NTS }\end{array}$ \\
\hline & & & & & $\begin{array}{l}10-31-1994 \\
11-07-1994 \\
11-09-1994 \\
11-30-1994 \\
12-02-1994\end{array}$ & $\begin{array}{c}-- \\
0953 \\
1025 \\
-- \\
0833\end{array}$ & $\begin{array}{l}3.45 \\
3.20 \\
3.18 \\
3.01 \\
2.95\end{array}$ & $\begin{array}{l}2,262.4 \\
2,262.7 \\
2,262.7 \\
2,262.9 \\
2,263.0\end{array}$ & $\begin{array}{l}\mathrm{S} \\
\mathrm{S} \\
\mathrm{S} \\
\mathrm{T} \\
\mathrm{S}\end{array}$ & $\begin{array}{l}- \\
: \\
-\end{array}$ & $\begin{array}{l}\text { USFWS } \\
\text { NTS } \\
\text { EMP } \\
\text { USFWS } \\
\text { NTS }\end{array}$ \\
\hline & & & & & $\begin{array}{l}12-19-1994 \\
12-21-1994 \\
12-23-1994\end{array}$ & $\begin{array}{c}0936 \\
1125 \\
--\end{array}$ & $\begin{array}{l}2.93 \\
2.92 \\
2.77\end{array}$ & $\begin{array}{l}2,263.0 \\
2,263.0 \\
2,263.1\end{array}$ & $\begin{array}{l}\mathrm{S} \\
\mathrm{S} \\
\mathrm{T}\end{array}$ & : & $\begin{array}{l}\text { NTS } \\
\text { EMP } \\
\text { USFWS }\end{array}$ \\
\hline AM- 2 & 362755116190401 & Five Springs Well & $2,367.4$ & 1.17 & $\begin{array}{l}01-19-1994 \\
02-15-1994 \\
03-22-1994 \\
03-28-1994 \\
04-05-1994\end{array}$ & $\begin{array}{l}1620 \\
1030 \\
1205 \\
1213 \\
1330\end{array}$ & $\begin{array}{l}-.56 \\
-.55 \\
-.58 \\
-.57 \\
. .58\end{array}$ & $\begin{array}{l}2,368.0 \\
2,368.0 \\
2,368.0 \\
2,368.0 \\
2,368.0\end{array}$ & $\begin{array}{l}\mathrm{S} \\
\mathrm{S} \\
\mathrm{S} \\
\mathrm{S} \\
\mathrm{S}\end{array}$ & $\begin{array}{l}\mathbf{F} \\
\mathbf{F} \\
\mathbf{F} \\
\mathbf{F} \\
\mathbf{F}\end{array}$ & $\begin{array}{l}\text { EMP } \\
\text { EMP } \\
\text { EMP } \\
\text { NTS } \\
\text { EMP }\end{array}$ \\
\hline & & & & & $\begin{array}{l}04-07-1994 \\
04-19-1994 \\
05-25-1994 \\
06-10-1994 \\
06-17-1994\end{array}$ & $\begin{array}{l}1025 \\
1340 \\
1100 \\
1150 \\
0113\end{array}$ & $\begin{array}{l}-.60 \\
-.60 \\
-.64 \\
-.61 \\
-.65\end{array}$ & $\begin{array}{l}2,368.0 \\
2,368.0 \\
2,368.0 \\
2,368.0 \\
2,368.0\end{array}$ & $\begin{array}{l}\text { S } \\
\text { S } \\
\text { S } \\
\text { S } \\
\text { S }\end{array}$ & $\begin{array}{l}\mathrm{F} \\
\mathrm{F} \\
\mathrm{F} \\
\mathrm{F} \\
\mathrm{F}\end{array}$ & $\begin{array}{l}\text { NTS } \\
\text { EMP } \\
\text { EMP } \\
\text { EMP } \\
\text { NTS }\end{array}$ \\
\hline
\end{tabular}


Table 5. Periodic measurements of water levels at monitoring sites in Yucca Mountain region for calendar year 1994-Continued

\begin{tabular}{|c|c|c|c|c|c|c|c|c|c|c|c|}
\hline \multirow[b]{2}{*}{$\begin{array}{c}\text { Site } \\
\text { number } \\
\text { (plate 1) }\end{array}$} & \multirow[b]{2}{*}{$\begin{array}{l}\text { U.S. Geological } \\
\text { Survey site } \\
\text { identification }\end{array}$} & \multirow[b]{2}{*}{ Site name } & \multirow{2}{*}{$\begin{array}{l}\text { Land- } \\
\text { surface } \\
\text { altitude } \\
\text { (feet } \\
\text { above } \\
\text { sea } \\
\text { level) }\end{array}$} & \multirow{2}{*}{$\begin{array}{l}\text { Height of } \\
\text { measure- } \\
\text { ment } \\
\text { point } \\
\text { (feet } \\
\text { above } \\
\text { land } \\
\text { surface) }\end{array}$} & \multicolumn{7}{|c|}{ Water-level measurement } \\
\hline & & & & & Date & Time & $\begin{array}{l}\text { Depth } \\
\text { to water } \\
\text { (feet } \\
\text { below } \\
\text { land } \\
\text { surface) }\end{array}$ & $\begin{array}{c}\text { Altitude } \\
\text { of water } \\
\text { surface } \\
\text { (feet } \\
\text { above } \\
\text { sea level) }\end{array}$ & Method & $\begin{array}{l}\text { Site } \\
\text { status }\end{array}$ & $\begin{array}{l}\text { Data } \\
\text { source }\end{array}$ \\
\hline \multirow[t]{2}{*}{ AM- 2} & 362755116190401 & Five Springs Well & $2,367.4$ & 1.17 & $\begin{array}{l}07-01-1994 \\
07-19-1994 \\
08-24-1994 \\
09-13-1994 \\
09-20-1994\end{array}$ & $\begin{array}{l}0817 \\
0915 \\
1154 \\
0834 \\
1205\end{array}$ & $\begin{array}{l}-.65 \\
-.65 \\
-.70 \\
-.75 \\
-.72\end{array}$ & $\begin{array}{l}2,368.0 \\
2,368.0 \\
2,368.1 \\
2,368.2 \\
2,368.1\end{array}$ & $\begin{array}{l}S \\
S \\
S \\
S \\
S\end{array}$ & $\begin{array}{l}F \\
F \\
F \\
F \\
F\end{array}$ & $\begin{array}{l}\text { NTS } \\
\text { EMP } \\
\text { EMP } \\
\text { NTS } \\
\text { EMP }\end{array}$ \\
\hline & & & & & $\begin{array}{l}10-18-1994 \\
11-09-1994 \\
12-01-1994 \\
12-14-1994\end{array}$ & $\begin{array}{l}1145 \\
1045 \\
1235 \\
1602\end{array}$ & $\begin{array}{l}-.70 \\
-.70 \\
-.68 \\
-.70\end{array}$ & $\begin{array}{l}2,368.1 \\
2,368.1 \\
2,368.1 \\
2,368.1\end{array}$ & $\begin{array}{l}S \\
S \\
S \\
S\end{array}$ & $\begin{array}{l}F \\
F \\
F \\
F\end{array}$ & $\begin{array}{l}\text { EMP } \\
\text { EMP } \\
\text { EMP } \\
\text { NTS }\end{array}$ \\
\hline \multirow[t]{3}{*}{$\mathrm{AM}-3$} & 362555116205301 & Garners Well & $2,157.0$ & 1.15 & $\begin{array}{l}01-19-1994 \\
02-15-1994 \\
03-22-1994 \\
04-07-1994 \\
04-19-1994\end{array}$ & $\begin{array}{l}1535 \\
1045 \\
1130 \\
0856 \\
1315\end{array}$ & $\begin{array}{l}19.15 \\
18.98 \\
18.72 \\
18.73 \\
18.75\end{array}$ & $\begin{array}{l}2,137.8 \\
2,138.0 \\
2,138.3 \\
2,138.3 \\
2,138.2\end{array}$ & $\begin{array}{l}S \\
S \\
S \\
S \\
S\end{array}$ & $\begin{array}{l}- \\
- \\
- \\
-\end{array}$ & $\begin{array}{l}\text { EMP } \\
\text { EMP } \\
\text { EMP } \\
\text { NTS } \\
\text { EMP }\end{array}$ \\
\hline & & & & & $\begin{array}{l}05-25-1994 \\
06-21-1994 \\
07-01-1994 \\
07-19-1994 \\
08-24-1994\end{array}$ & $\begin{array}{l}1135 \\
1020 \\
0950 \\
0845 \\
1045\end{array}$ & $\begin{array}{l}18.93 \\
19.27 \\
19.42 \\
19.69 \\
20.25\end{array}$ & $\begin{array}{l}2,138.1 \\
2,137.7 \\
2,137.6 \\
2,137.3 \\
2,136.8\end{array}$ & $\begin{array}{l}S \\
S \\
S \\
S \\
S\end{array}$ & $\begin{array}{l}- \\
- \\
-\end{array}$ & $\begin{array}{l}\text { EMP } \\
\text { EMP } \\
\text { NTS } \\
\text { EMP } \\
\text { EMP }\end{array}$ \\
\hline & & & & & $\begin{array}{l}09-13-1994 \\
09-20-1994 \\
10-18-1994 \\
11-09-1994 \\
12-21-1994\end{array}$ & $\begin{array}{l}0658 \\
1125 \\
1040 \\
0855 \\
1100\end{array}$ & $\begin{array}{l}20.43 \\
20.54 \\
20.63 \\
20.59 \\
20.41\end{array}$ & $\begin{array}{l}2,136.6 \\
2,136.5 \\
2,136.4 \\
2,136.4 \\
2,136.6\end{array}$ & $\begin{array}{l}S \\
S \\
S \\
S \\
S\end{array}$ & $\begin{array}{l}- \\
- \\
-\end{array}$ & $\begin{array}{l}\text { NTS } \\
\text { EMP } \\
\text { EMP } \\
\text { EMP } \\
\text { EMP }\end{array}$ \\
\hline \multirow[t]{2}{*}{ AM- 4} & 362532116172700 & Devils Hole & $2,359.9$ & -- & $\begin{array}{l}02-15-1994 \\
02-16-1994 \\
03-15-1994 \\
04-15-1994 \\
05-15-1994\end{array}$ & $\begin{array}{c}- \\
1130 \\
-- \\
- \\
-\end{array}$ & $\begin{array}{l}2.01 \\
1.99 \\
1.99 \\
1.98 \\
2.01\end{array}$ & $\begin{array}{l}2,357.9 \\
2,357.9 \\
2,357.9 \\
2,357.9 \\
2,357.9\end{array}$ & $\begin{array}{l}\text { A } \\
\text { N } \\
\text { A } \\
\text { A } \\
\text { A }\end{array}$ & $\begin{array}{l}- \\
- \\
-\end{array}$ & $\begin{array}{l}\text { NPS } \\
\text { EMP } \\
\text { NPS } \\
\text { NPS } \\
\text { NPS }\end{array}$ \\
\hline & & & & & $\begin{array}{l}05-26-1994 \\
06-15-1994 \\
07-15-1994 \\
08-15-1994 \\
08-24-1994\end{array}$ & $\begin{array}{c}1135 \\
-- \\
- \\
- \\
1300\end{array}$ & $\begin{array}{l}2.13 \\
2.02 \\
2.03 \\
2.05 \\
2.09\end{array}$ & $\begin{array}{l}2,357.8 \\
2,357.9 \\
2,357.9 \\
2,357.8 \\
2,357.8\end{array}$ & $\begin{array}{l}\text { N } \\
\text { A } \\
\text { A } \\
\text { A } \\
\text { N }\end{array}$ & $\begin{array}{l}- \\
- \\
- \\
-\end{array}$ & $\begin{array}{l}\text { EMP } \\
\text { NPS } \\
\text { NPS } \\
\text { NPS } \\
\text { EMP }\end{array}$ \\
\hline
\end{tabular}


Table 5. Periodic measurements of water levels at monitoring sites in Yucca Mountain region for calendar year 1994—Continued

\begin{tabular}{|c|c|c|c|c|c|c|c|c|c|c|c|}
\hline \multirow[b]{2}{*}{$\begin{array}{c}\text { Site } \\
\text { number } \\
\text { (plate 1) }\end{array}$} & \multirow[b]{2}{*}{$\begin{array}{l}\text { U.S. Geological } \\
\text { Survey site } \\
\text { Identification }\end{array}$} & \multirow[b]{2}{*}{ Site name } & \multirow{2}{*}{$\begin{array}{c}\text { Land- } \\
\text { surface } \\
\text { altitude } \\
\text { (feet } \\
\text { above } \\
\text { sea } \\
\text { level) }\end{array}$} & \multirow{2}{*}{$\begin{array}{l}\text { Height of } \\
\text { measure- } \\
\text { ment } \\
\text { point } \\
\text { (feet } \\
\text { above } \\
\text { land } \\
\text { surface) }\end{array}$} & \multicolumn{7}{|c|}{ Water-level measurement } \\
\hline & & & & & Date & Time & $\begin{array}{l}\text { Depth } \\
\text { to water } \\
\text { (feet } \\
\text { below } \\
\text { land } \\
\text { surface) }\end{array}$ & $\begin{array}{c}\text { Altitude } \\
\text { of water } \\
\text { surface } \\
\text { (feet } \\
\text { above } \\
\text { sea level) }\end{array}$ & Method & $\begin{array}{c}\text { Site } \\
\text { status }\end{array}$ & $\begin{array}{c}\text { Data } \\
\text { source }\end{array}$ \\
\hline AM- 4 & 362532116172700 & Devils Hole & $2,359.9$ & -- & $\begin{array}{l}10-15-1994 \\
11-09-1994 \\
11-15-1994 \\
12-15-1994\end{array}$ & $\begin{array}{c}-\ddot{1000} \\
- \\
--\end{array}$ & $\begin{array}{l}2.08 \\
1.98 \\
2.10 \\
2.06\end{array}$ & $\begin{array}{l}2,357.8 \\
2,357.9 \\
2,357.8 \\
2,357.8\end{array}$ & $\begin{array}{l}\mathrm{A} \\
\mathrm{N} \\
\mathrm{A} \\
\mathrm{A}\end{array}$ & $\begin{array}{l}- \\
- \\
-\end{array}$ & $\begin{array}{l}\text { NPS } \\
\text { EMP } \\
\text { NPS } \\
\text { NPS }\end{array}$ \\
\hline AM- 5 & 362529116171100 & Devils Hole Well & $2,404.1$ & 0.9 & $\begin{array}{l}01-12-1994 \\
01-19-1994 \\
01-25-1994 \\
02-15-1994 \\
02-16-1994\end{array}$ & $\begin{array}{c}1519 \\
1645 \\
- \\
1104 \\
0720\end{array}$ & $\begin{array}{l}48.08 \\
47.94 \\
48.03 \\
47.96 \\
47.93\end{array}$ & $\begin{array}{l}2,356.0 \\
2,356.2 \\
2,356.1 \\
2,356.1 \\
2,356.2\end{array}$ & $\begin{array}{l}\mathrm{S} \\
\mathrm{S} \\
\mathrm{S} \\
\mathrm{S} \\
\mathrm{S}\end{array}$ & $\begin{array}{l}- \\
: \\
-\end{array}$ & $\begin{array}{l}\text { NTS } \\
\text { EMP } \\
\text { USFWS } \\
\text { EMP } \\
\text { NTS }\end{array}$ \\
\hline & & & & & $\begin{array}{l}02-28-1994 \\
03-10-1994 \\
03-22-1994 \\
03-28-1994 \\
03-28-1994 \\
03-30-1994\end{array}$ & $\begin{array}{c}-- \\
1331 \\
1230 \\
1253 \\
1539 \\
--\end{array}$ & $\begin{array}{l}48.02 \\
47.91 \\
47.83 \\
48.05 \\
48.99 \\
48.02\end{array}$ & $\begin{array}{l}2,356.1 \\
2,356.2 \\
2,356.3 \\
2,355.0 \\
2,356.1 \\
2,356.1\end{array}$ & $\begin{array}{l}\mathbf{S} \\
\mathbf{S} \\
\mathbf{S} \\
\mathbf{S} \\
\mathrm{S} \\
\mathrm{S}\end{array}$ & $\begin{array}{l}: \\
: \\
-\end{array}$ & $\begin{array}{l}\text { USFWS } \\
\text { NTS } \\
\text { EMP } \\
\text { NTS } \\
\text { NTS } \\
\text { USFWS }\end{array}$ \\
\hline & & & & & $\begin{array}{l}04-06-1994 \\
04-19-1994 \\
04-29-1994 \\
04-29-1994 \\
05-11-1994\end{array}$ & $\begin{array}{l}1343 \\
1425 \\
0919 \\
1200 \\
0822\end{array}$ & $\begin{array}{l}47.93 \\
47.93 \\
48.05 \\
48.09 \\
48.02\end{array}$ & $\begin{array}{l}2,356.2 \\
2,365.2 \\
2,356.0 \\
2,356.0 \\
2,356.1\end{array}$ & $\begin{array}{l}\mathrm{S} \\
\mathrm{S} \\
\mathrm{S} \\
\mathrm{S} \\
\mathrm{S}\end{array}$ & $\begin{array}{l}- \\
-\end{array}$ & $\begin{array}{l}\text { NTS } \\
\text { EMP } \\
\text { NTS } \\
\text { USFWS } \\
\text { NTS }\end{array}$ \\
\hline & & & & & $\begin{array}{l}05-25-1994 \\
05-26-1994 \\
05-31-1994 \\
06-16-1994 \\
06-21-1994\end{array}$ & $\begin{array}{c}1024 \\
1313 \\
1331 \\
1531 \\
1120\end{array}$ & $\begin{array}{l}48.05 \\
48.06 \\
48.09 \\
48.06 \\
48.12\end{array}$ & $\begin{array}{l}2,356.0 \\
2,356.0 \\
2,356.0 \\
2,356.0 \\
2,356.0\end{array}$ & $\begin{array}{l}\mathrm{S} \\
\mathrm{S} \\
\mathrm{S} \\
\mathrm{S} \\
\mathrm{S}\end{array}$ & :- & $\begin{array}{l}\text { EMP } \\
\text { NTS } \\
\text { USFWS } \\
\text { NTS } \\
\text { EMP }\end{array}$ \\
\hline & & & & & $\begin{array}{l}06-28-1994 \\
06-30-1994 \\
07-12-1994 \\
07-19-1994 \\
07-26-1994\end{array}$ & $\begin{array}{c}-. \\
1823 \\
1322 \\
0950 \\
0738\end{array}$ & $\begin{array}{l}48.04 \\
48.01 \\
48.05 \\
48.13 \\
48.05\end{array}$ & $\begin{array}{l}2,356.1 \\
2,356.1 \\
2,356.0 \\
2,356.0 \\
2,356.0\end{array}$ & $\begin{array}{l}\mathrm{S} \\
\mathrm{S} \\
\mathrm{S} \\
\mathrm{S} \\
\mathrm{S}\end{array}$ & $\begin{array}{l}- \\
- \\
-\end{array}$ & $\begin{array}{l}\text { USFWS } \\
\text { NTS } \\
\text { NTS } \\
\text { EMP } \\
\text { NTS }\end{array}$ \\
\hline & & & & & $\begin{array}{l}07-26-1994 \\
07-26-1994 \\
08-02-1994 \\
08-11-1994 \\
08-16-1994\end{array}$ & $\begin{array}{l}1200 \\
1313 \\
0858 \\
1237 \\
1000\end{array}$ & $\begin{array}{l}48.05 \\
48.09 \\
48.13 \\
48.87 \\
48.10\end{array}$ & $\begin{array}{l}2,356.0 \\
2,356.0 \\
2,356.0 \\
2,356.0 \\
2,356.0\end{array}$ & $\begin{array}{l}\text { S } \\
\text { S } \\
\text { S } \\
\text { S } \\
\text { S }\end{array}$ & $\begin{array}{l}- \\
- \\
-\end{array}$ & $\begin{array}{l}\text { NTS } \\
\text { USFWS } \\
\text { NTS } \\
\text { NTS } \\
\text { EMP }\end{array}$ \\
\hline & & & & & $\begin{array}{l}08-30-1994 \\
09-12-1994 \\
09-20-1994 \\
09-28-1994 \\
09-29-1994\end{array}$ & $\begin{array}{c}10 \\
1041 \\
1250 \\
1244 \\
-.\end{array}$ & $\begin{array}{l}47.99 \\
48.90 \\
48.02 \\
47.99 \\
47.99\end{array}$ & $\begin{array}{l}2,356.1 \\
2,356.1 \\
2,356.1 \\
2,356.1 \\
2,356.1\end{array}$ & $\begin{array}{l}\mathrm{S} \\
\mathrm{S} \\
\mathrm{S} \\
\mathrm{S} \\
\mathrm{S}\end{array}$ & $\begin{array}{l}- \\
:\end{array}$ & $\begin{array}{l}\text { USFWS } \\
\text { NTS } \\
\text { EMP } \\
\text { NTS } \\
\text { USFWS }\end{array}$ \\
\hline
\end{tabular}


Table 5. Periodic measurements of water levels at monitoring sites in Yucca Mountain region for calendar year 1994-Continued

\begin{tabular}{|c|c|c|c|c|c|c|c|c|c|c|c|}
\hline \multirow[b]{2}{*}{$\begin{array}{c}\text { Site } \\
\text { number } \\
\text { (plate 1) }\end{array}$} & \multirow[b]{2}{*}{$\begin{array}{l}\text { U.S. Geological } \\
\text { Survey site } \\
\text { identification }\end{array}$} & \multirow[b]{2}{*}{ Site name } & \multirow[b]{2}{*}{$\begin{array}{l}\text { Land- } \\
\text { surface } \\
\text { altitude } \\
\text { (feet } \\
\text { above } \\
\text { sea } \\
\text { level) }\end{array}$} & \multirow{2}{*}{$\begin{array}{l}\text { Height'of } \\
\text { measure- } \\
\text { ment } \\
\text { point } \\
\text { (feet } \\
\text { above } \\
\text { land } \\
\text { surface) }\end{array}$} & \multicolumn{7}{|c|}{ Water-level measurement } \\
\hline & & & & & Date & Time & $\begin{array}{l}\text { Depth } \\
\text { to water } \\
\text { (feet } \\
\text { below } \\
\text { land } \\
\text { surface) }\end{array}$ & $\begin{array}{c}\text { Altitude } \\
\text { of water } \\
\text { surface } \\
\text { (feet } \\
\text { above } \\
\text { sea level) }\end{array}$ & Method & $\begin{array}{c}\text { Site } \\
\text { status }\end{array}$ & $\begin{array}{l}\text { Data } \\
\text { source }\end{array}$ \\
\hline \multirow[t]{2}{*}{ AM- 5} & 362529116171100 & Devils Hole Well & $2,404.1$ & 0.9 & $\begin{array}{l}10-18-1994 \\
10-21-1994 \\
10-31-1994 \\
11-07-1994 \\
11-09-1994\end{array}$ & $\begin{array}{c}1230 \\
1211 \\
-- \\
1346 \\
0925\end{array}$ & $\begin{array}{l}48.06 \\
48.08 \\
48.13 \\
48.00 \\
48.02\end{array}$ & $\begin{array}{l}2,356.0 \\
2,356.0 \\
2,356.0 \\
2,356.1 \\
2,356.1\end{array}$ & $\begin{array}{l}S \\
S \\
S \\
S \\
S\end{array}$ & $\begin{array}{l}- \\
- \\
- \\
-\end{array}$ & $\begin{array}{l}\text { EMP } \\
\text { NTS } \\
\text { USFWS } \\
\text { NTS } \\
\text { EMP }\end{array}$ \\
\hline & & & & & $\begin{array}{l}11-30-1994 \\
12-02-1994 \\
12-19-1994 \\
12-21-1994 \\
12-23-1994\end{array}$ & $\begin{array}{c}- \\
1147 \\
1334 \\
1215 \\
--\end{array}$ & $\begin{array}{l}48.05 \\
48.02 \\
48.08 \\
48.08 \\
48.01\end{array}$ & $\begin{array}{l}2,356.0 \\
2,356.1 \\
2,356.0 \\
2,356.0 \\
2,356.1\end{array}$ & $\begin{array}{l}T \\
S \\
S \\
S \\
T\end{array}$ & $\begin{array}{l}- \\
- \\
- \\
-\end{array}$ & $\begin{array}{l}\text { USFWS } \\
\text { NTS } \\
\text { NTS } \\
\text { EMP } \\
\text { USFWS }\end{array}$ \\
\hline \multirow[t]{6}{*}{ AM- 6} & 362432116165701 & Point of Rocks North Well & $2,318.8$ & .0 & $\begin{array}{l}01-19-1994 \\
01-25-1994 \\
02-15-1994 \\
02-28-1994 \\
03-22-1994\end{array}$ & $\begin{array}{c}1605 \\
-- \\
1200 \\
- \\
1257\end{array}$ & $\begin{array}{l}20.98 \\
21.08 \\
21.04 \\
21.08 \\
20.96\end{array}$ & $\begin{array}{l}2,297.8 \\
2,297.7 \\
2,297.8 \\
2,297.7 \\
2,297.8\end{array}$ & $\begin{array}{l}S \\
S \\
S \\
S \\
S\end{array}$ & $\begin{array}{l}- \\
- \\
- \\
-\end{array}$ & $\begin{array}{l}\text { EMP } \\
\text { USFWS } \\
\text { EMP } \\
\text { USFWS } \\
\text { EMP }\end{array}$ \\
\hline & & & & & $\begin{array}{l}03-28-1994 \\
03-30-1994 \\
04-06-1994 \\
04-19-1994 \\
04-29-1994\end{array}$ & $\begin{array}{c}1505 \\
- \\
1209 \\
1455 \\
--\end{array}$ & $\begin{array}{l}21.03 \\
21.04 \\
21.08 \\
21.10 \\
21.10\end{array}$ & $\begin{array}{l}2,297.8 \\
2,297.8 \\
2,297.7 \\
2,297.7 \\
2,297.7\end{array}$ & $\begin{array}{l}S \\
S \\
S \\
S \\
S\end{array}$ & $\begin{array}{l}- \\
- \\
- \\
-\end{array}$ & $\begin{array}{l}\text { NTS } \\
\text { USFWS } \\
\text { NTS } \\
\text { EMP } \\
\text { USFWS }\end{array}$ \\
\hline & & & & & $\begin{array}{l}05-25-1994 \\
05-31-1994 \\
06-10-1994 \\
06-17-1994 \\
06-28-1994\end{array}$ & $\begin{array}{c}0925 \\
-- \\
1235 \\
1015 \\
--\end{array}$ & $\begin{array}{l}21.24 \\
21.28 \\
21.27 \\
21.24 \\
21.24\end{array}$ & $\begin{array}{l}2,297.6 \\
2,297.5 \\
2,297.5 \\
2,297.6 \\
2,297.6\end{array}$ & $\begin{array}{l}S \\
S \\
S \\
S \\
S\end{array}$ & $\begin{array}{l}- \\
- \\
- \\
-\end{array}$ & $\begin{array}{l}\text { EMP } \\
\text { USFWS } \\
\text { EMP } \\
\text { NTS } \\
\text { USFWS }\end{array}$ \\
\hline & & & & & $\begin{array}{l}07-01-1994 \\
07-19-1994 \\
07-26-1994 \\
08-25-1994 \\
08-30-1994\end{array}$ & $\begin{array}{c}1146 \\
1025 \\
-- \\
0845 \\
--\end{array}$ & $\begin{array}{l}21.24 \\
21.24 \\
21.25 \\
21.26 \\
21.29\end{array}$ & $\begin{array}{l}2,297.6 \\
2,297.6 \\
2,297.6 \\
2,297.5 \\
2,297.5\end{array}$ & $\begin{array}{l}S \\
S \\
S \\
S \\
S\end{array}$ & $\begin{array}{l}- \\
- \\
- \\
-\end{array}$ & $\begin{array}{l}\text { NTS } \\
\text { EMP } \\
\text { USFWS } \\
\text { EMP } \\
\text { USFWS }\end{array}$ \\
\hline & & & & & $\begin{array}{l}09-12-1994 \\
09-20-1994 \\
09-29-1994 \\
10-18-1994 \\
10-31-1994\end{array}$ & $\begin{array}{c}0744 \\
1325 \\
-- \\
1300 \\
--\end{array}$ & $\begin{array}{l}21.23 \\
21.23 \\
21.25 \\
21.21 \\
21.20\end{array}$ & $\begin{array}{l}2,297.6 \\
2,297.6 \\
2,297.6 \\
2,297.6 \\
2,297.6\end{array}$ & $\begin{array}{l}S \\
S \\
S \\
S \\
S\end{array}$ & $\begin{array}{l}- \\
- \\
- \\
-\end{array}$ & $\begin{array}{l}\text { NTS } \\
\text { EMP } \\
\text { USFWS } \\
\text { EMP } \\
\text { USFWS }\end{array}$ \\
\hline & & & & & $\begin{array}{l}11-09-1994 \\
11-30-1994 \\
12-21-1994 \\
12-22-1994\end{array}$ & $\begin{array}{c}1145 \\
-- \\
1240 \\
--\end{array}$ & $\begin{array}{l}21.16 \\
21.25 \\
21.18 \\
21.15\end{array}$ & $\begin{array}{l}2,297.6 \\
2,297.6 \\
2,297.6 \\
2,297.6\end{array}$ & $\begin{array}{l}\mathrm{S} \\
\mathrm{T} \\
\mathrm{S} \\
\mathrm{T}\end{array}$ & $\begin{array}{l}- \\
- \\
-\end{array}$ & $\begin{array}{l}\text { EMP } \\
\text { USFWS } \\
\text { EMP } \\
\text { USFWS }\end{array}$ \\
\hline
\end{tabular}


Table 5. Periodic measurements of water levels at monitoring sites in Yucca Mountain region for calendar year 1994-Continued

\begin{tabular}{|c|c|c|c|c|c|c|c|c|c|c|c|}
\hline \multirow[b]{2}{*}{$\begin{array}{c}\text { Site } \\
\text { number } \\
\text { (plate 1) }\end{array}$} & \multirow[b]{2}{*}{$\begin{array}{l}\text { U.S. Geological } \\
\text { Survey site } \\
\text { identification }\end{array}$} & \multirow[b]{2}{*}{ Site name } & \multirow[b]{2}{*}{$\begin{array}{c}\text { Land- } \\
\text { surface } \\
\text { altitude } \\
\text { (feet } \\
\text { above } \\
\text { sea } \\
\text { level) }\end{array}$} & \multirow{2}{*}{$\begin{array}{l}\text { Height of } \\
\text { measure- } \\
\text { ment } \\
\text { point } \\
\text { (feet } \\
\text { above } \\
\text { land } \\
\text { surface) }\end{array}$} & \multicolumn{7}{|c|}{ Water-level measurement } \\
\hline & & & & & Date & Time & $\begin{array}{l}\text { Depth } \\
\text { to water } \\
\text { (feet } \\
\text { below } \\
\text { land } \\
\text { surface) }\end{array}$ & $\begin{array}{c}\text { Altitude } \\
\text { of water } \\
\text { surface } \\
\text { (feet } \\
\text { above } \\
\text { sea level) }\end{array}$ & Method & $\begin{array}{c}\text { Site } \\
\text { status }\end{array}$ & $\begin{array}{c}\text { Data } \\
\text { source }\end{array}$ \\
\hline \multirow[t]{8}{*}{ AM- 7} & 362417116163600 & Point of Rocks South Well & $2,333.5$ & 0.8 & $\begin{array}{l}01-12-1994 \\
01-19-1994 \\
01-25-1994 \\
02-14-1994 \\
02-15-1994\end{array}$ & $\begin{array}{c}1553 \\
1740 \\
-123 \\
1123 \\
1245\end{array}$ & $\begin{array}{l}9.65 \\
8.96 \\
8.94 \\
9.17 \\
9.17\end{array}$ & $\begin{array}{l}2,323.8 \\
2,324.5 \\
2,324.6 \\
2,324.3 \\
2,324.3\end{array}$ & $\begin{array}{l}\text { S } \\
\text { S } \\
\text { S } \\
\text { S } \\
\text { S }\end{array}$ & $\begin{array}{l}: \\
\vdots\end{array}$ & $\begin{array}{l}\text { NTS } \\
\text { EMP } \\
\text { USFWS } \\
\text { NTS } \\
\text { EMP }\end{array}$ \\
\hline & & & & & $\begin{array}{l}02-28-1994 \\
03-10-1994 \\
03-22-1994 \\
03-28-1994 \\
03-30-1994\end{array}$ & $\begin{array}{c}- \\
0944 \\
1310 \\
1400 \\
-. .\end{array}$ & $\begin{array}{l}9.32 \\
9.35 \\
9.30 \\
9.42 \\
9.42\end{array}$ & $\begin{array}{l}2,324.2 \\
2,324.2 \\
2,324.2 \\
2,324.1 \\
2,324.1\end{array}$ & $\begin{array}{l}\text { S } \\
\text { S } \\
\text { S } \\
\text { S } \\
\text { S }\end{array}$ & $\begin{array}{l}- \\
- \\
-\end{array}$ & $\begin{array}{l}\text { USFWS } \\
\text { NTS } \\
\text { EMP } \\
\text { NTS } \\
\text { USFWS }\end{array}$ \\
\hline & & & & & $\begin{array}{l}04-06-1994 \\
04-19-1994 \\
04-29-1994 \\
04-29-1994 \\
05-11-1994\end{array}$ & $\begin{array}{l}1147 \\
1510 \\
0903 \\
1200 \\
1300\end{array}$ & $\begin{array}{l}9.45 \\
9.41 \\
9.53 \\
9.57 \\
9.46\end{array}$ & $\begin{array}{l}2,324.0 \\
2,324.1 \\
2,324.0 \\
2,323.9 \\
2,324.0\end{array}$ & $\begin{array}{l}\text { S } \\
\text { S } \\
\text { S } \\
\text { S } \\
\text { S }\end{array}$ & $\begin{array}{l}- \\
- \\
-\end{array}$ & $\begin{array}{l}\text { NTS } \\
\text { EMP } \\
\text { NTS } \\
\text { USFWS } \\
\text { NTS }\end{array}$ \\
\hline & & & & & $\begin{array}{l}05-25-1994 \\
05-26-1994 \\
05-31-1994 \\
06-10-1994 \\
06-17-1994\end{array}$ & $\begin{array}{c}0955 \\
1223 \\
-- \\
1255 \\
0915\end{array}$ & $\begin{array}{l}9.47 \\
9.46 \\
9.40 \\
9.37 \\
9.18\end{array}$ & $\begin{array}{l}2,324.0 \\
2,324.0 \\
2,324.1 \\
2,324.1 \\
2,324.3\end{array}$ & $\begin{array}{l}\text { S } \\
\text { S } \\
\text { S } \\
\text { S } \\
\text { S }\end{array}$ & $\begin{array}{l}- \\
- \\
-\end{array}$ & $\begin{array}{l}\text { EMP } \\
\text { NTS } \\
\text { USFWS } \\
\text { EMP } \\
\text { NTS }\end{array}$ \\
\hline & & & & & $\begin{array}{l}06-17-1994 \\
06-28-1994 \\
06-30-1994 \\
07-01-1994 \\
07-12-1994\end{array}$ & $\begin{array}{c}1359 \\
-- \\
1956 \\
1215 \\
1106\end{array}$ & $\begin{array}{l}9.14 \\
9.17 \\
9.13 \\
9.12 \\
9.13\end{array}$ & $\begin{array}{l}2,324.4 \\
2,324.3 \\
2,324.4 \\
2,324.4 \\
2,324.4\end{array}$ & $\begin{array}{l}\text { S } \\
\text { S } \\
\text { S } \\
\text { S } \\
\text { S }\end{array}$ & $\begin{array}{l}- \\
- \\
-\end{array}$ & $\begin{array}{l}\text { NTS } \\
\text { USFWS } \\
\text { NTS } \\
\text { NTS } \\
\text { NTS }\end{array}$ \\
\hline & & & & & $\begin{array}{l}07-19-1994 \\
07-26-1994 \\
08-11-1994 \\
08-25-1994 \\
08-30-1994\end{array}$ & $\begin{array}{c}1045 \\
- \\
1138 \\
0910 \\
--\end{array}$ & $\begin{array}{l}9.20 \\
9.16 \\
9.10 \\
9.07 \\
9.07\end{array}$ & $\begin{array}{l}2,324.3 \\
2,324.3 \\
2,324.4 \\
2,324.4 \\
2,324.4\end{array}$ & $\begin{array}{l}\text { S } \\
\text { S } \\
\text { S } \\
\text { S } \\
\text { S }\end{array}$ & $\begin{array}{l}- \\
- \\
-\end{array}$ & $\begin{array}{l}\text { EMP } \\
\text { USFWS } \\
\text { NTS } \\
\text { EMP } \\
\text { USFWS }\end{array}$ \\
\hline & & & & & $\begin{array}{l}09-12-1994 \\
09-20-1994 \\
09-28-1994 \\
09-29-1994 \\
10-18-1994\end{array}$ & $\begin{array}{c}0805 \\
1345 \\
1312 \\
- \\
1320\end{array}$ & $\begin{array}{l}9.03 \\
9.00 \\
9.00 \\
9.00 \\
9.02\end{array}$ & $\begin{array}{l}2,324.5 \\
2,324.5 \\
2,324.5 \\
2,324.5 \\
2,324.5\end{array}$ & $\begin{array}{l}\text { S } \\
\text { S } \\
\text { S } \\
\text { S } \\
\text { S }\end{array}$ & $\begin{array}{l}- \\
: \\
-\end{array}$ & $\begin{array}{l}\text { NTS } \\
\text { EMP } \\
\text { NTS } \\
\text { USFWS } \\
\text { EMP }\end{array}$ \\
\hline & & & & & $\begin{array}{l}10-19-1994 \\
10-19-1994 \\
10-21-1994 \\
10-31-1994 \\
11-07-1994\end{array}$ & $\begin{array}{c}1400 \\
1500 \\
1333 \\
-\ddot{1438}\end{array}$ & $\begin{array}{l}9.03 \\
9.01 \\
9.03 \\
9.06 \\
8.95\end{array}$ & $\begin{array}{l}2,324.5 \\
2,324.5 \\
2,324.5 \\
2,324.4 \\
2,324.6\end{array}$ & $\begin{array}{l}\mathbf{S} \\
\mathbf{S} \\
\mathbf{S} \\
\mathbf{S} \\
\mathbf{S}\end{array}$ & $:$ & $\begin{array}{l}\text { NTS } \\
\text { NTS } \\
\text { NTS } \\
\text { USFWS } \\
\text { NTS }\end{array}$ \\
\hline
\end{tabular}


Table 5. Periodic measurements of water levels at monitoring sites in Yucca Mountain region for calendar year 1994-Continued

\begin{tabular}{|c|c|c|c|c|c|c|c|c|c|c|c|}
\hline \multirow[b]{2}{*}{$\begin{array}{c}\text { Site } \\
\text { number } \\
\text { (plate 1) }\end{array}$} & \multirow[b]{2}{*}{$\begin{array}{l}\text { U.S. Geological } \\
\text { Survey site } \\
\text { identification }\end{array}$} & \multirow[b]{2}{*}{ Site name } & \multirow[b]{2}{*}{$\begin{array}{l}\text { Land- } \\
\text { surface } \\
\text { altitude } \\
\text { (feet } \\
\text { above } \\
\text { sea } \\
\text { level) }\end{array}$} & \multirow{2}{*}{$\begin{array}{c}\text { Height of } \\
\text { measure- } \\
\text { ment } \\
\text { point } \\
\text { (feet } \\
\text { above } \\
\text { land } \\
\text { surface) }\end{array}$} & \multicolumn{7}{|c|}{ Water-level measurement } \\
\hline & & & & & Date & Time & $\begin{array}{l}\text { Depth } \\
\text { to water } \\
\text { (feet } \\
\text { below } \\
\text { land } \\
\text { surface) }\end{array}$ & $\begin{array}{c}\text { Altitude } \\
\text { of water } \\
\text { surface } \\
\text { (feet } \\
\text { above } \\
\text { sea level) }\end{array}$ & Method & $\begin{array}{c}\text { Site } \\
\text { status }\end{array}$ & $\begin{array}{c}\text { Data } \\
\text { source }\end{array}$ \\
\hline AM- 7 & 362417116163600 & Point of Rocks South Well & $2,333.5$ & 0.8 & $\begin{array}{l}11-09-1994 \\
11-30-1994 \\
12-02-1994 \\
12-19-1994 \\
12-21-1994 \\
12-22-1994\end{array}$ & $\begin{array}{c}1215 \\
\ldots- \\
1229 \\
1436 \\
1305 \\
-.\end{array}$ & $\begin{array}{l}8.94 \\
8.94 \\
8.92 \\
8.90 \\
8.90 \\
8.90\end{array}$ & $\begin{array}{l}2,324.6 \\
2,324.6 \\
2,324.6 \\
2,324.6 \\
2,324.6 \\
2,324.6\end{array}$ & $\begin{array}{l}\mathrm{S} \\
\mathrm{T} \\
\mathrm{S} \\
\mathrm{S} \\
\mathrm{S} \\
\mathrm{T}\end{array}$ & $\begin{array}{l}- \\
- \\
- \\
- \\
-\end{array}$ & $\begin{array}{l}\text { EMP } \\
\text { USFWS } \\
\text { NTS } \\
\text { NTS } \\
\text { EMP } \\
\text { USFWS }\end{array}$ \\
\hline DV- 3 & 362230116392901 & Travertine Point 1 Well & $2,728.4$ & 2.0 & $\begin{array}{l}01-18-1994 \\
02-14-1994 \\
03-21-1994 \\
04-18-1994 \\
05-24-1994\end{array}$ & $\begin{array}{l}1425 \\
1415 \\
1340 \\
1410 \\
1010\end{array}$ & $\begin{array}{l}598.58 \\
598.60 \\
598.75 \\
598.83 \\
598.93\end{array}$ & $\begin{array}{l}2,129.8 \\
2,129.8 \\
2,129.6 \\
2,129.6 \\
2,129.5\end{array}$ & $\begin{array}{l}\mathrm{V} \\
\mathrm{V} \\
\mathrm{V} \\
\mathrm{V} \\
\mathrm{V}\end{array}$ & $\begin{array}{l}- \\
- \\
-\end{array}$ & $\begin{array}{l}\text { EMP } \\
\text { EMP } \\
\text { EMP } \\
\text { EMP } \\
\text { EMP }\end{array}$ \\
\hline & & & & & $\begin{array}{l}06-21-1994 \\
07-19-1994 \\
08-23-1994 \\
09-19-1994 \\
10-17-1994\end{array}$ & $\begin{array}{l}0850 \\
0720 \\
0745 \\
1420 \\
1505\end{array}$ & $\begin{array}{l}599.05 \\
599.12 \\
599.22 \\
599.29 \\
599.42\end{array}$ & $\begin{array}{l}2,129.4 \\
2,129.3 \\
2,129.2 \\
2,129.1 \\
2,129.0\end{array}$ & $\begin{array}{l}\mathrm{V} \\
\mathrm{V} \\
\mathrm{V} \\
\mathrm{V} \\
\mathrm{V}\end{array}$ & $\begin{array}{l}- \\
: \\
-\end{array}$ & $\begin{array}{l}\text { EMP } \\
\text { EMP } \\
\text { EMP } \\
\text { EMP } \\
\text { EMP }\end{array}$ \\
\hline & & & & & $\begin{array}{l}11-08-1994 \\
12-19-1994\end{array}$ & $\begin{array}{l}0805 \\
1410\end{array}$ & $\begin{array}{l}599.47 \\
599.61\end{array}$ & $\begin{array}{l}2,128.9 \\
2,128.8\end{array}$ & $\begin{array}{l}\mathrm{V} \\
\mathrm{V}\end{array}$ & - & $\begin{array}{l}\text { EMP } \\
\text { EMP }\end{array}$ \\
\hline
\end{tabular}




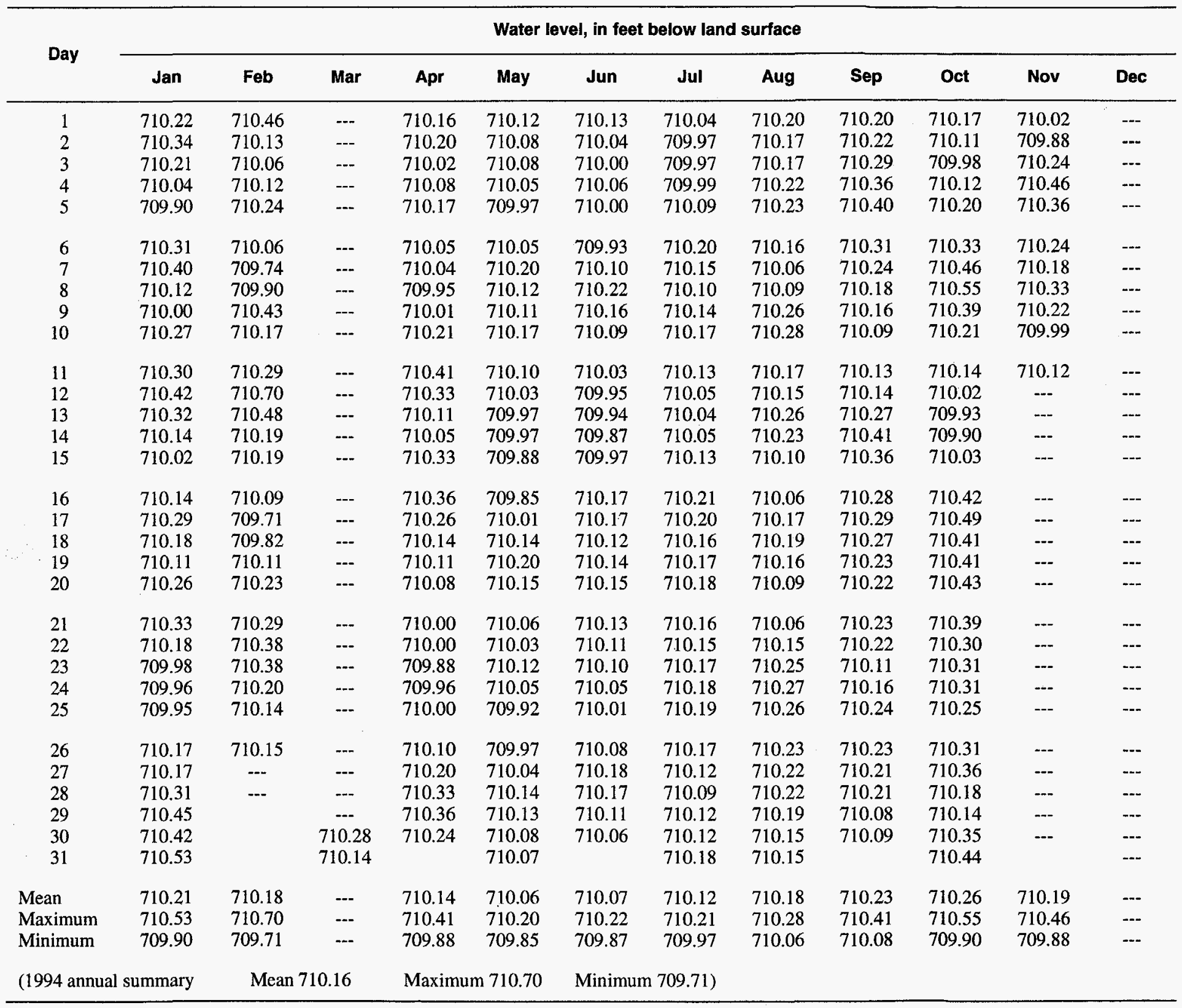


Table 7. Daily average water levels in well AD-6 for calendar year 1994

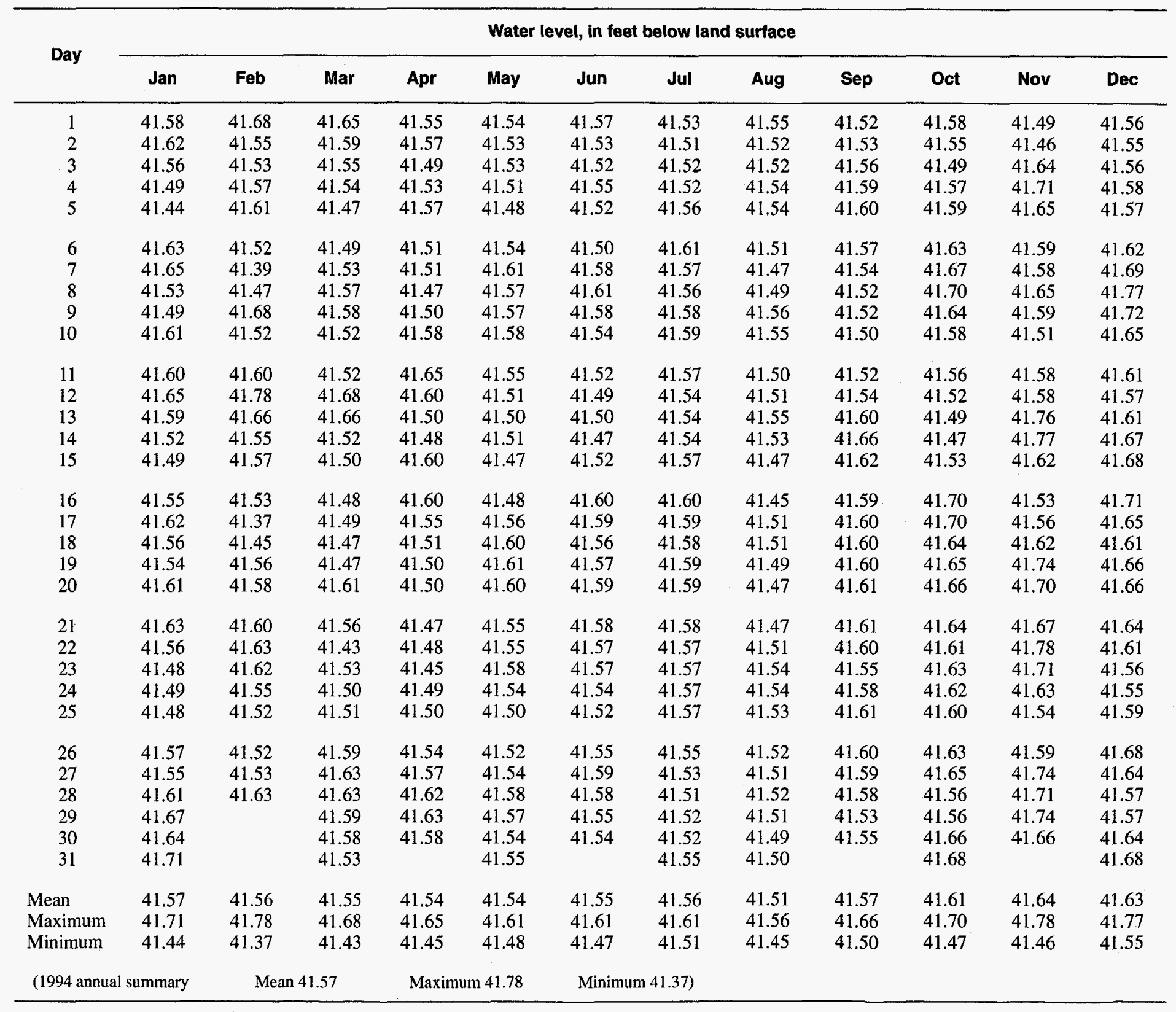


Table 8. Ground-water-discharge data in Yucca Mountain region for calendar year 1994

Site number: Sites are grouped by hydrographic area and, within each area, are listed in general north-to-south, then west-to-east order. See text section titled "Site Number" for further discussion.

U.S. Geological.Survey site identification: Unique identification number for site as stored in files and data bases of U.S. Geological Survey.

Time: Time measurement was made, in military time; --, measurement time unknown.

Discharge: Reported to two significant figures.

Method: Method used to measure discharge. $C$, current meter; F, depth of water measured in flume and converted to discharge, on basis of applicable discharge table for Parshall flume; V, volumetric; $Z$, discharge represents monthly mean discharge.

Data source: EMP, Environmental-Monitoring Program (U.S. Geological Survey); NPS, National Park Service; USFWS, U.S. Fish and Wildlife Service; USGS-NV, other Nevada District programs (U.S. Geological Survey)

\begin{tabular}{|c|c|c|c|c|c|c|c|}
\hline \multirow{2}{*}{$\begin{array}{c}\text { Site } \\
\text { number } \\
\text { (plate 1) }\end{array}$} & \multirow{2}{*}{$\begin{array}{l}\text { U.S.Geological } \\
\text { Survey site } \\
\text { identification }\end{array}$} & \multirow{2}{*}{ Site name } & \multicolumn{5}{|c|}{ Discharge measurement } \\
\hline & & & Date & Time & $\begin{array}{l}\text { Discharge } \\
\text { (gallons per minute) }\end{array}$ & Method & $\begin{array}{l}\text { Data } \\
\text { source }\end{array}$ \\
\hline \multirow[t]{4}{*}{ AM-1a } & 362924116203001 & Fairbanks Spring & $02-16-1994$ & 0950 & 1,500 & $\mathrm{C}$ & EMP \\
\hline & & & $05-26-1994$ & 0800 & 1,800 & $\mathrm{~F}$ & EMP \\
\hline & & & $08-24-1994$ & 0900 & 1,500 & C & EMP \\
\hline & & & $11-15-1994$ & 0800 & 1,500 & $\mathrm{C}$ & EMP \\
\hline \multirow[t]{10}{*}{ AM-2 } & 362755116190401 & Five Springs Well & 04-15-1994 & 1330 & 7.3 & V & EMP \\
\hline & & & 04-19-1994 & 1340 & 6.2 & V & EMP \\
\hline & & & 05-25-1994 & 1100 & 2.6 & V & EMP \\
\hline & & & 06-10-1994 & 1150 & 2.4 & V & EMP \\
\hline & & & $06-17-1994$ & 1130 & 2.3 & V & EMP \\
\hline & & & $07-19-1994$ & 0930 & 1.9 & $\mathrm{~V}$ & EMP \\
\hline & & & $08-24-1994$ & 1155 & 1.4 & V & EMP \\
\hline & & & $10-18-1994$ & 1145 & 2.4 & V & EMP \\
\hline & & & $11-09-1994$ & 1050 & 2.6 & $\mathrm{~V}$ & EMP \\
\hline & & & $12-01-1994$ & 1240 & 3.6 & V & EMP \\
\hline \multirow[t]{17}{*}{ AM-5a } & 362502116192301 & Crystal Pool & 01-25-1994 & -- & 2,600 & $\mathrm{C}$ & USFWS \\
\hline & & & 02-16-1994 & 1205 & 2,700 & $\mathrm{C}$ & EMP \\
\hline & & & $02-28-1994$ & -- & 2,600 & $\mathrm{C}$ & USFWS \\
\hline & & & 03-30-1994 & -- & 2,600 & $\mathrm{C}$ & USFWS \\
\hline & & & 04-08-1994 & -- & 2,200 & C & USGS-NV \\
\hline & & & 04-29-1994 & -- & 2,500 & $\mathrm{C}$ & USFWS \\
\hline & & & $05-26-1994$ & 1238 & 2,600 & $\mathrm{C}$ & EMP \\
\hline & & & $05-31-1994$ & -- & 2,400 & $\mathrm{C}$ & USFWS \\
\hline & & & $06-28-1994$ & -- & 2,400 & $\mathrm{C}$ & USFWS \\
\hline & & & $07-27-1994$ & -- & 2,400 & $\mathrm{C}$ & USFWS \\
\hline & & & $08-25-1994$ & 1321 & 2,700 & $\mathrm{C}$ & EMP \\
\hline & & & $08-30-1994$ & - & 2,400 & $\mathrm{C}$ & USFWS \\
\hline & & & $09-29-1994$ & -- & 2,300 & $\mathrm{C}$ & USFWS \\
\hline & & & $10-31-1994$ & iste & 2,400 & $\mathrm{C}$ & USFWS \\
\hline & & & $11-15-1994$ & 1355 & 2,400 & $\mathrm{C}$ & EMP \\
\hline & & & $11-30-1994$ & -- & 2,500 & $\mathrm{C}$ & USFWS \\
\hline & & & $12-22-1994$ & -- & 2,500 & $\mathrm{C}$ & USFWS \\
\hline
\end{tabular}


Table 8. Ground-water-discharge data in Yucca Mountain region for calendar year 1994-Continued

\begin{tabular}{|c|c|c|c|c|c|c|c|}
\hline \multirow{2}{*}{$\begin{array}{c}\text { Site } \\
\text { number } \\
\text { (plate 1) }\end{array}$} & \multirow{2}{*}{$\begin{array}{l}\text { U.S.Geological } \\
\text { Survey site } \\
\text { identification }\end{array}$} & \multirow{2}{*}{ Site name } & \multicolumn{5}{|c|}{ Discharge measurement } \\
\hline & & & Date & Time & $\begin{array}{c}\text { Discharge } \\
\text { (gallons per minute) }\end{array}$ & Method & $\begin{array}{l}\text { Data } \\
\text { source }\end{array}$ \\
\hline \multirow[t]{17}{*}{ AM-8 } & 362230116162001 & Big Spring & 01-24-1994 & -- & 1,000 & $\mathrm{C}$ & USFWS \\
\hline & & & 02-16-1994 & 1346 & 1,200 & $\mathrm{C}$ & EMP \\
\hline & & & $02-28-1994$ & - & 1,000 & $\mathrm{C}$ & USFWS \\
\hline & & & 03-30-1994 & -- & 1,100 & $\mathrm{C}$ & USFWS \\
\hline & & & 04-29-1994 & & 1,300 & $\mathrm{C}$ & USFWS \\
\hline & & & 05-26-1994 & 0930 & 970 & $\mathrm{C}$ & EMP \\
\hline & & & 05-31-1994 & - & 1,400 & $\mathrm{C}$ & USFWS \\
\hline & & & $06-28-1994$ & -- & 1,400 & $\mathrm{C}$ & USFWS \\
\hline & & & $07-27-1994$ & -- & 1,000 & $\mathrm{C}$ & USFWS \\
\hline & & & 08-25-1994 & 1025 & 860 & $\mathrm{C}$ & EMP \\
\hline & & & 08-30-1994 & -- & 1,100 & $\mathrm{C}$ & USFWS \\
\hline & & & $09-29-1994$ & -- & 860 & $\mathrm{C}$ & USFWS \\
\hline & & & 10-31-1994 & -- & 820 & $\mathrm{C}$ & USFWS \\
\hline & & & $11-25-1994$ & 1100 & 950 & $\mathrm{C}$ & EMP \\
\hline & & & $11-30-1994$ & - & 890 & $\mathrm{C}$ & USFWS \\
\hline & & & 12-01-1994 & 1035 & 920 & $\mathrm{C}$ & EMP \\
\hline & & & 12-22-1994 & -- & 890 & $\mathrm{C}$ & USFWS \\
\hline \multirow[t]{17}{*}{ DV-1 } & 362728116501101 & Texas Spring & 01-15-1994 & -- & 200 & $\mathrm{Z}$ & NPS \\
\hline & & & 02-14-1994 & 1547 & 200 & $\mathrm{C}$ & EMP \\
\hline & & & 02-15-1994 & -- & 200 & $\mathrm{Z}$ & NPS \\
\hline & & & 03-15-1994 & -- & 210 & $\mathrm{Z}$ & NPS \\
\hline & & & 04-15-1994 & -- & 210 & $\mathrm{Z}$ & NPS \\
\hline & & & 05-15-1994 & -- & 200 & $\mathrm{Z}$ & NPS \\
\hline & & & 05-24-1994 & 1152 & 210 & $\mathrm{C}$ & EMP \\
\hline & & & 06-15-1994 & -- & 200 & $\mathrm{Z}$ & NPS \\
\hline & & & 07-15-1994 & -- & 200 & $\mathrm{Z}$ & NPS \\
\hline & & & 08-15-1994 & -- & 200 & $\mathrm{Z}$ & NPS \\
\hline & & & 08-23-1994 & 0915 & 240 & $\mathrm{C}$ & EMP \\
\hline & & & 09-15-1994 & -- & 190 & $\mathrm{Z}$ & NPS \\
\hline & & & $10-15-1994$ & -- & 200 & $\mathrm{Z}$ & NPS \\
\hline & & & 11-14-1994 & 1445 & 270 & $\mathrm{C}$ & EMP \\
\hline & & & $11-15-1994$ & & 200 & $\mathrm{Z}$ & NPS \\
\hline & & & 11-30-1994 & 1415 & 210 & $\mathrm{C}$ & EMP \\
\hline & & & $12-15-1994$ & 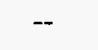 & 200 & $\mathrm{Z}$ & NPS \\
\hline \multirow[t]{4}{*}{ DV-2 } & 362252116425301 & Navel Spring & 02-14-1994 & 1715 & 1.7 & V & EMP \\
\hline & & & 05-24-1994 & 1325 & 1.5 & V & EMP \\
\hline & & & 08-23-1994 & 1100 & 1.3 & V & EMP \\
\hline & & & $11-08-1994$ & 1030 & 1.4 & V & EMP \\
\hline
\end{tabular}


Table 9. Estimated annual ground-water withdrawals from wells in Yucca Mountain region for calendar year 1994

\begin{tabular}{llccc}
\hline \multirow{2}{*}{ Ground-water subbasin } & Hydrographic area & \multicolumn{3}{c}{ Ground-water withdrawal $^{\text {1 }}$} \\
\cline { 3 - 5 } & & Year & $\begin{array}{c}\text { Millions of } \\
\text { gallons }\end{array}$ & Acre-feet \\
\hline Alkali Flat-Furnace Creek Ranch & Amargosa Desert $^{2}$ & 1994 & 3,987 & 12,235 \\
& Crater Flat $^{3}$ & 1991 & 13.9 & 43 \\
& & 1992 & 9.5 & 29 \\
& & 1993 & 4.9 & 15 \\
Ash Meadows & Jackass Flats $^{3}$ & 1994 & 14.8 & 45 \\
& Mercury Valley $^{3}$ & 1994 & 90.2 & 277 \\
\hline
\end{tabular}

${ }^{1}$ See section "Ground-Water Withdrawals" for discussion of data sources.

${ }^{2}$ Data recompiled from ground-water pumpage inventory for entire Amargosa Desert, listed to nearest acre-foot. Conversion to million of gallons are rounded to nearest 1 million gallons. All withdrawals for Amargosa Desert are included in Alkali Flat-Furnace Creek Ranch ground-water subbasin because data were not available to exclude withdrawals within Ash Meadows subbasin.

${ }^{3}$ Data recompiled from flowmeter readings listed to nearest 0.1 million gallons. Conversions to acre-feet are rounded to nearest acre-foot. 
Table 10. Minimum, maximum, and median water-level altitudes, and average deviation of measurements, at wells in Jackass Flats for selected baseline periods and for calendar years 1992 through 1994.

Excludes water-level altitudes that may reflect possible transient conditions at a site.

Calendar vears: Years for which measurements were used to calculate summary statistics. Italics indicate selected baseline period.

Number: Number of water-level measurements for year(s) specified. For JF-2 (1985-93), JF-2a, and JF-3, value represents number of daily average water levels.

Water level: Based on discrete water-level measurements made during site visits for JF-1, JF-2 (in 1994), J-13, J-11, and J-12. Based on daily average water levels collected from continual data recorders for JF-2 (1985-93), JF-2a, and JF-3.

Minimum: Minimum water-level altitude or minimum daily average water level for year(s) specified.

Maximum: Maximum water-level altitude or maximum daily average water level for year(s) specified.

Median: Statistically representative water-level altitude calculated from discrete measurements or daily average water levels for year(s) specified.

Average deviation: Calculated dispersion of measurements about median water-level altitude. Average deviation is equal to sum of absolute differences between measured water levels and median, divided by number of measurements.

Change in median: Differences between median water level for calendar years 1992, 1993, and 1994 compared with baseline period. Minus sign indicates that median water-level altitude was lower for the specified year compared with the baseline period.

[Abbreviations and symbols: N/A, not applicable (data field is not related to referenced data set)]

\begin{tabular}{|c|c|c|c|c|c|c|c|}
\hline \multirow{2}{*}{$\begin{array}{c}\text { Site } \\
\text { number } \\
\text { (plate 1) }\end{array}$} & \multirow{2}{*}{$\begin{array}{c}\text { Calendar } \\
\text { year(s) }\end{array}$} & \multirow{2}{*}{ Number } & \multicolumn{3}{|c|}{ Water level (feet above sea level) } & \multirow{2}{*}{$\begin{array}{c}\text { Average } \\
\text { deviation } \\
\text { (feet) }\end{array}$} & \multirow{2}{*}{$\begin{array}{c}\text { Change in } \\
\text { median } \\
\text { (feet) }\end{array}$} \\
\hline & & & Minimum & Maximum & Median & & \\
\hline JF-1 & $1985-91$ & 86 & $2,391.7$ & $2,393.1$ & $2,392.5$ & 0.2 & $\mathrm{~N} / \mathrm{A}$ \\
\hline $\mathrm{JF}-2$ & $1985-91$ & 1,777 & $2,389.6$ & $2,393.4$ & $2,392.1$ & .3 & $\mathrm{~N} / \mathrm{A}$ \\
\hline JF-2a & $1985-91$ & 1,876 & $2,466.7$ & $2,469.5$ & $2,468.6$ & .4 & $\mathrm{~N} / \mathrm{A}$ \\
\hline $\mathrm{J}-13$ & $1989-91$ & 32 & $2,389.7$ & $2,390.7$ & $2,390.0$ & .2 & $\mathrm{~N} / \mathrm{A}$ \\
\hline $\mathrm{J}-11$ & $1990-91$ & 25 & $2,401.9$ & $2,402.9$ & $2,402.2$ & .1 & N/A \\
\hline $\mathrm{J}-12$ & $1990-91$ & 22 & $2,388.1$ & $2,388.5$ & $2,388.3$ & .1 & N/A \\
\hline JF-3 & $1992-93$ & 582 & $2,387.7$ & $2,388.8$ & $2,388.3$ & .1 & N/A \\
\hline JF-1 & 1992 & 12 & $2,392.3$ & $2,392.6$ & $2,392.4$ & 0.1 & -0.1 \\
\hline JF-2 & 1992 & 357 & $2,391.8$ & $2,392.6$ & $2,392.2$ & .1 & .1 \\
\hline$J F-2 a$ & 1992 & 342 & $2,466.9$ & $2,469.2$ & $2,468.6$ & .5 & 0.0 \\
\hline $\mathbf{J}-13$ & 1992 & 21 & $2,389.6$ & $2,390.4$ & $2,389.9$ & .1 & -.1 \\
\hline $\mathrm{J}-11$ & 1992 & 12 & $2,402.0$ & $2,402.6$ & $2,402.2$ & .1 & 0.0 \\
\hline $\mathrm{J}-12$ & 1992 & 17 & $2,388.2$ & $2,388.6$ & $2,388.3$ & .1 & 0.0 \\
\hline JF-3 & 1992 & 217 & $2,387.8$ & $2,388.6$ & $2,388: 2$ & .1 & $\mathrm{~N} / \mathrm{A}$ \\
\hline JF-1 & 1993 & 8 & $2,391.9$ & $2,392.7$ & $2,392.5$ & 0.2 & 0.0 \\
\hline JF-2 & 1993 & 362 & $2,391.7$ & $2,392.8$ & $2,392.1$ & .2 & 0.0 \\
\hline$J F-2 a$ & 1993 & 365 & $2,468.4$ & $2,469.2$ & $2,468.8$ & .1 & .2 \\
\hline $\mathrm{J}-13$ & 1993 & 16 & $2,389.7$ & $2,390.7$ & $2,389.9$ & .1 & -.1 \\
\hline $\mathrm{J}-11$ & 1993 & 8 & $2,401.9$ & $2,402.7$ & $2,402.2$ & .2 & 0.0 \\
\hline $\mathrm{J}-12$ & 1993 & 19 & $2,387.9$ & $2,389.0$ & $2,388.3$ & .1 & 0.0 \\
\hline JF-3 & 1993 & 365 & $2,387.7$ & $2,388.8$ & $2,388.3$ & .1 & N/A \\
\hline JF-1 & 1994 & 12 & $2,392.1$ & $2,392.6$ & $2,392.3$ & 0.1 & -0.2 \\
\hline JF-2 & 1994 & 9 & $2,392.0$ & $2,392.6$ & $2,392.2$ & .1 & .1 \\
\hline JF-2a & 1994 & 356 & $2,468.4$ & $2,469.4$ & $2,469.0$ & .1 & .4 \\
\hline $\mathrm{J}-13$ & 1994 & 23 & $2,389.4$ & $2,390.0$ & $2,389.7$ & .1 & -.3 \\
\hline J-11 & 1994 & 12 & $2,402.0$ & $2,402.5$ & $2,402.3$ & .1 & .1 \\
\hline $\mathrm{J}-12$ & 1994 & 24 & $2,387.8$ & $2,389.1$ & $2,388.2$ & .2 & -.1 \\
\hline JF-3 & 1994 & 284 & $2,387.6$ & $2,388.6$ & $2,388.1$ & .1 & -.2 \\
\hline
\end{tabular}


The distribution code for this report is UC-814. 

